\author{
UNIVERSIDADE DE SÃO PAULO DE SÃO PAULO \\ FACULDADE DE FILOSOFIA LETRAS E CIÊNCIAS HUMANAS \\ DEPARTAMENTO DE LETRAS MODERNAS \\ PROGRAMA DE LÍNGUA, LITERATURA E CULTURA ITALIANAS
}

\title{
A MULHER NA VISÃO POÉTICA DE DANTE
}

TADEU DA SILVA MACÊDO

SÃO PAULO 


\author{
UNIVERSIDADE DE SÃO PAULO \\ FACULDADE DE FILOSOFIA LETRAS E CIÊNCIAS HUMANAS \\ DEPARTAMENTO DE LETRAS MODERNAS \\ PROGRAMA DE LÍNGUA, LITERATURA E CULTURA ITALIANAS
}

\title{
A MULHER NA VISÃO POÉTICA DE DANTE
}

Tadeu da Silva Macêdo

Dissertação apresentada ao programa de pós-graduação em Língua, Literatura e Cultura Italianas do Departamento de Letras Modernas da Faculdade de Filosofia, Letras e Ciências Humanas da Universidade de São Paulo para obtenção do título de Mestre em Letras.

Orientadora: Prof ${ }^{\mathrm{a}}$. Dr ${ }^{\mathrm{a}}$. Vilma De Katinsky Barreto Souza

Aprovado em 30/10/2012

Versão corrigida, contendo as alterações sugeridas pela banca de defesa

Exemplar original disponível para consulta no CAPH da FFLCH (Centro de Apoio à Pesquisa Histórica)

De acordo:

Profa. Dra. Vilma De Katinsky Barreto Souza 
2012

AUTORIZO A REPRODUÇÃO E DIVULGAÇÃO TOTAL OU PARCIAL DESTE TRABALHO, POR QUALQUER MEIO CONVENCIONAL OU ELETRÔNICO, PARA FINS DE ESTUDO E PESQUISA, DESDE QUE CITADA A FONTE. 


\author{
UNIVERSIDADE DE SÃO PAULO \\ FACULDADE DE FILOSOFIA, LTRAS E CIÊNCIAS HUMANAS \\ DEPARTAMENTO DE LETRAS MODERNAS \\ PROGRAMA DE PÓS-GRADUAÇÃO EM LITERATURA ITALIANA
}

\title{
DISSERTAÇÃO PARA OBTENÇÃO DO GRAU DE MESTRE
}

\section{BANCA DE DEFESA}

\section{Titulares}

Profa. Dra. Maria Teresa Arrigoni

Profa. Dra. Mauricio Santana Dias

Profa. Dra. Vilma De Katinsky Barreto Souza (orientadora)

\section{Suplentes}

Profa. Dra. Lucia Wataghin

Prof. Dr. Pedro Haise Faleiros 


\section{Dedicatória}

É sobre a mulher esta dissertação e para elas dedico, em particular: a minha mãe, dona do maior amor, aquele que nos aproxima do infinito e nos mostra a face de Deus.

A Alba Brito Mascarenhas, amiga, escritora, professora e mentora intelectual, desde a escolha do curso de graduação até as últimas linhas deste trabalho.

E à professora Vilma De Katinsky Barreto pelo carinho em ter confiado na minha vontade de estudar Dante, dando-me toda a orientação.

Como diria Dante: Di donne io vidi una gentil schiera... 
Agradecimentos

À professora Vilma De Katinsky Barreto pelo carinho e cuidados durante os anos de orientação, por ter me aceitado e confiado como orientando apresentandome a USP.

A todos dos grupos de pesquisa, sobre a obra de Dante e o de Literatura Traduzida, nos quais fui acolhido de forma intensa.

Aos professores Lucia Wataghin, Maria Tereza Arrigoni, Cecilia Casini, Paola Baccin e Mauricio Santana Dias.

Aos amigos cruspianos: Rodrigo, André Calazans, Dario, Thiago, Artemir, Lígia, Júnior, enfim, a todos que participaram de minha trajetória.

Aos queridos Edith e Júnior pelo apoio junto ao Departamento de Letras Modernas.

À minha diretora, Edna Rodrigues, aos professores e funcionários da Escola João XXIII.

A Capes pelo apoio financeiro durante os anos da pesquisa sem o qual não poderia chegar até o final.

Ao professor italiano Alessandro Mammi pelas indicações bibliográficas e conselhos para a composição do texto.

Aos amigos da minha cidade Baixa Grande, na Bahia, o meu carinho.

A meus irmãos Tarcisio e Taize.

A Igor, pela presença e cuidado.

A todos os meus agradecimentos pela composição desta etapa! 


\section{Resumo}

Dante Alighieri foi poeta medieval que escreveu para a mulher versos amorosos em um período de profunda misoginia. Muitas são as presenças femininas nas suas poesias da fase lírica anterior à criação da Divina Comédia. Este estudo centra com especial atenção a visão que o poeta constrói da mulher durante a sua fase experimentalista e de escambo poético com amigos da escola poética florentina, o doce estilo novo, apontando que a linguagem e a visão da mulher são construídas durante esse período e estão presentes também na composição da Comédia, em particular no Inferno, Canto $V$, onde figura Francesca da Rimini, e no Purgatório com Matelda. Estas mulheres fazem com que o poeta recorde os pressupostos da escola poética fundada com seus jovens amigos.

Palavras-chave: Dante Alighieri, Divina Comédia, rimas, mulheres, doce estilo novo. 


\begin{abstract}
Dante Alighieri was a medieval poet who wrote his lines to the woman living during a very deeply misosynist age. There is a lot of feminine presence in his juvenile lyric poetry's creation, before the Divina Commedia. This work focuses especial attention to the construction of the role playing of the women during his exprementalist fase with his florentines youthful friends of dolce stil nuovo, pointing for the language and the representations of women continuous presents in his magnum opus, showing that language as the vision of the women, both contructed during this period, presents on the Cantic V, Inferno, with Francesca da Rimini and, on the Purgatorio with Matelda. This woman brings the memories of the beginning of Dante's school founded with his friends.
\end{abstract}

Key-words: Dante Alighieri, Divine Comedie, lyric poetry, women, dolce stil nuovo. 


\section{Riassunto}

Dante Alighieri fu poeta medievale e scrisse versi d'amore alle donne in un periodo di profonda misoginia. $\mathrm{Ci}$ sono molte presenze femminili nelle sue composizioni poetiche ancora prima della creazione della Commedia. Questo studio si concentra con particolare attenzione sulla visione che il poeta costruisce della donna durante la sua fase sperimentale e quella di scambi poetici con gli amici della scuola florentina, il dolce stil nuovo, accennando come il linguaggio e la visione della donna costruite in questo periodo sono anche presenti nella Commedia, in particolare nel Canto V dell'Inferno con la figura di Francesca da Rimini e nel Purgatorio con l'apparizione di Matelda, donne che fanno il poeta ricordarsi della sua intima relazione con la scuola poetica da lui fondata con gli amici.

Parole chiave: Dante Alighieri, Divina Commedia, rime, donna, dolce stil nuovo. 
SUMÁRIO

Página

1. INTRODUÇÃO

2. A MULHER MEDIEVAL

2.1. A FEIÇÃO E O COMPORTAMENTO DA MULHER MEDIEVAL

2.2. MATILDE DE CANOSSA: UM MITO FEMININO NA ITÁLIA DE DANTE

3. O FEMININO EM DANTE

3.1 DANTE E O DOCE ESTILO NOVO

3.2 DANTE E O CONCEITO DE MULHER NA SUA LÍRICA JUVENIL

3.3 PRESENÇAS E IMAGENS FEMININAS NA LÍRICA DE DANTE

4. MULHERES ADVERSAS OU ANTÍPODAS A BEATRIZ

4.1 FRANCESCA DA RIMINI

4.2 MATELDA

5. CONCLUSÃO

6. REFERÊNCIAS BIBLIOGRÁFICAS 


\section{INTRODUÇÃO}

A lírica de Dante Alighieri reúne características particulares e inovadoras. As experiências vivenciadas pelo próprio poeta, bem como o modelo poético provençal são importantes na criação de novos elementos para a poesia na Itália, que com Alighieri ganha, sem dúvida, uma fisionomia original.

A poesia provençal encontra o seu tom característico ao cantar o amor cuja temática principal é a relação homem versus mulher. Vale destacar que foi na Provença, região da França, que surgiu esse modelo de criação poética, responsável por fundir valores da corte à poesia, propagando por toda a Europa o encanto do verso amoroso.

Os poetas trovadores são os seus difusores, especialmente os convidados para abrilhantar as festas das cortes. Por isso, essa poesia apresenta uma natureza móvel, que encontra no talento do trovador espaços diferenciados de representação. Amadurecida em ambientes díspares, seja cultural ou economicamente, tal arte encontrou no reino da Sicília, no século XII, em particular na corte do rei Frederico II, um ambiente propício para sua difusão.

Ao chegar a terras Toscanas, a experiência poética amorosa passava por um processo de ambientação, sendo que já havia sido reformulada pela corte de Frederico II. Nesse contexto, a poesia deixa de ser palaciana para adentrar em círculos de amigos poetas, não mais de trovadores, já que essa estrutura havia perdido espaço. Nascia, portanto, o poeta local, aquele poeta da cidade em ascensão, não mais vinculado a uma corte e sim a grupos preocupados em tornar a poesia um momento de troca, uma experiência de seita.

Dante, pode-se dizer, foi um poeta da cidade, em particular de Florença, lugar que servia de encontro para os grandes nomes da poesia da Toscana, sendo uma importante cidade para a fundação de uma escola, um movimento literário, fundado por Alighieri e seus amigos, que ficou conhecido como, i fedeli d' amore, os fiéis ao amor. Tais poetas esboçaram em suas composições um espaço particular, onde a mulher figurava como centro do verso. 
Através das composições líricas de Dante, ainda em sua fase experimentalista, na qual o poeta era seguidor da poética de Guido Cavalcanti, pretendemos navegar pelas rimas de sua fase de aprendizagem na arte poética, na tentativa de apontar o processo de construção da imagem feminina.

Diante das muitas edições críticas das Rimas, editadas ao longo do tempo, assim como da Vida Nova, delimitamos no que se referem às rimas, a edição do estudioso italiano Gorni. A escolha de tais poemas para tentar apresentar a construção da imagem feminina, elaborada por Dante no período de aprendizagem poética, pautou-se a partir da presença de figuras e imagens poéticas alusivas à mulher.

É importante esclarecer que, antes de apresentar a imagem da mulher, elaborada poeticamente por Dante, faz-se necessário compreender a história da mulher, que sempre foi contada a partir do olhar masculino, avesso a uma relação de igualdade com o sexo feminino. Vale ressaltar que a participação da mulher na sociedade medieval era limitada à reprodução e aos cuidados domésticos; qualquer participação dela, fora dessa esfera, gerava discussões e confrontos, dada a forte influência da Igreja Católica, poder absoluto na época em estudo.

Os escritos oriundos dos padres da Igreja, apoiados na Bíblia, orientavam o homem a ver o corpo da mulher como tabernáculo do mal, para tanto os pensadores escolásticos medievais serviam-se da história da criação de Eva, cujo modelo feminino justificava a inferioridade desse sexo nas relações.

Desde a criação bíblica do universo, Eva foi a responsável pela queda do homem e pela sua sujeição ao pecado; a mulher era vista como ser capaz de aproximar o homem do diabo, sendo que essa chave de leitura legava à mulher medieval grandes problemas de inserção e participação nas relações sociais. Podese dizer que a grande redentora de Eva é Maria, responsável pelo intenso fluxo devocional no século XIII, pois Maria redime Eva, propiciando à mulher um espaço mais aprazível na sociedade.

O culto mariano construirá um novo perfil feminino, no qual a mulher além de cuidar da casa e ser mãe, deverá ser devota à oração, ou seja, seguir as pegadas de Maria, mãe do Salvador, na busca pela redenção. Muitas mulheres, orientadas 
por essa perspectiva, encontraram na vida de oração o caminho. As ordens religiosas fundadas no século XII, a exemplo dos franciscanos, buscaram resgatar a mulher guiando-as ao caminho da salvação.

A poesia amorosa, de raiz provençal no século XIII, encontra no culto mariano uma mulher propícia para ser tema das suas composições; se antes a mulher era 0 centro da poesia, com o culto a virgem Maria, o modelo ganha ainda mais força.

Atreladas a Eva ou à Santa Maria, o universo feminino nos séculos XIII e XIV ainda convive com a forte influência de ser dependente do homem. A história de Eloísa e Abelardo, por exemplo, mostra como um desejo amoroso pode ser reprimido pela ideia de inferioridade feminina, que pertencendo à natureza humana, prevalece graças à fé no amor.

Essa orientação para a vivência de uma sexualidade castrada, guiada pelo modelo mariano, afasta a mulher de funções antes ocupadas estritamente pelos homens. Para desfazer essa ideia, surge a Condessa Matelda de Canossa, uma mulher atípica para sua época, dona de um grande poder político, que soube gerir com mão de ferro os feudos deixados pelo seu pai, no norte da atual Itália. Ela foi responsável por fixar a paz entre as intrigas políticas, envolvendo o Imperador Henrique IV e o Papa Gregório VII, na briga pelo estabelecimento do poder.

Após uma leitura histórica do papel da mulher na sociedade medieval, no segundo capítulo deste trabalho, voltaremos nosso olhar ao estudo das composições líricas dantesca, apontando o surgimento de diversas figuras femininas já na sua poesia experimentalista. Importante lembrar que as composições poéticas de Dante foram divididas, pelos estudiosos de sua obra, em: rimas da fase experimentalista, de correspondência, alegóricas e aquelas que formam o livro da Vida Nova, juntas compondo a produção lírica anterior à criação da Comédia.

Barbi (1956) foi o responsável por organizar a produção lírica de Dante, já que não se pode enquadrar a poesia dantesca na ideia de cancioneiro, dado a falta de unidade temática, fator inexistente nessas produções. A obra Vida Nova, composta por um grupo de poesias seguidas de comentários em prosa, aponta para uma ideia de unidade, entretanto, não chega a ter o caráter de cancioneiro como muitos estudiosos costumam definir. 
As trocas poéticas feitas entre Dante e amigos da envergadura de Guido Cavalcanti, como Dante da Maiano, Forese Donati entre outros, apresentam características da escola poética fundada em Florença, responsável por fazer surgir um novo conceito de mulher. O doce estilnovo foi fruto de experiências e trocas poéticas que resultaram na criação de conceitos particulares para a lírica amorosa medieval.

Nessas composições a figura da mulher adquire status de ser angelical eliminando a roupagem humana, muito presente nas produções anteriores, e atuando como guia na produção dantesca até a Vida Nova. As poesias de escambo com amigos figuram imagens femininas já próximas de Maria, ou seja, uma mulher sem nenhuma característica real. A criação do prosimetro, Vida Nova, apresenta a grande fase dantesca do estilnovo, momento da aparição de Beatriz musa absoluta do poeta.

As aparições de outras figuras femininas em poemas das rimas, sejam aquelas das extravagantes ou presentes na Vida Nova, dão a dimensão das inúmeras mulheres presentes na poesia de Dante, sendo que essas manifestações se dão através de vocábulos criados especificamente pelos poetas da escola estilnovista. O famoso soneto Donne che avete intelleto d'amori é o manifesto fundador desse novo estilo.

Essa poesia cria um novo conceito amoroso, a maneira de criação é modificada e essa mudança é sentida por poetas da escola sículo-toscana a exemplo de, Buonagiunta Orbicianni, que em um soneto endereçado aos poetas da escola Toscana - os estilnovistas - replica a forma dos poetas em tentar mudar a forma de produzir poesia.

Em grande parte das poesias de Dante, a mulher se presentifica através de um léxico particular, colocando em debate a profunda relação da poesia estilnovista com a figura feminina, seu núcleo fundante. A maioria das composições da fase experimentalista apresenta mulheres distantes e muito próximas a Beatriz, que na criação da Vida Nova é coroada como única no universo do poeta.

O manifesto dos estilnovistas demonstra a forte relação entre a poesia e a filosofia, outro elemento agregado ao quadro poético dessa escola, que gerará uma 
poesia mais complexa, exigindo maior racionalização. Não à toa, Dante introduz sempre nos seus poemas a questão do intelecto como fator mediador para uma compreensão mais clara da sua poesia.

As muitas mulheres presentes na fase de aprendizagem poética de Dante são fruto da nova escola, que tem como seus maiores representantes Guido Guinizelli e Guido Cavalcanti, ambos reconhecidos por Dante como seus mestres na arte da poesia. As trocas poéticas com seus pares fazem com que Dante elabore um conceito novo para sua poesia no que se refere à mulher, conceito que escorre até a composição da Divina Comédia.

Ao nomear a mulher como anjo, como portadora de sabedoria, Donne che avete inteletto d'amori, o poeta eleva a mulher à condição quase divina. Essa nova maneira de tratar o sexo feminino na poesia vai acompanhá-lo até a Comédia. No Canto V do Inferno surge Francesca, dita da Rimini, trazendo consigo marcas do estilnovo, cujo léxico presente é característico dessa escola.

A figura de Matelda nos Cantos finais do Purgatório evidencia um Dante ainda preso à poesia amorosa e estilnovista. Matelda aparece como símbolo da purificação, seus movimentos e seu discurso levam a rememorar os versos da poesia da sua fase juvenil. As mulheres da Comédia, em particular Francesca, presente no Inferno, assim como Matelda, guardiã do jardim do Éden, podem ser vistas como evidências de que Dante tem uma imagem da mulher ainda muito ligada àquela criada pela escola estilnovista. 


\section{A MULHER MEDIEVAL}

Pouco ou quase nada se escreveu sobre a mulher do período medieval o que se sabe é narrado a partir do olhar masculino que busca reafirmar fatos históricos de dominação, muitas vezes compreendidos de maneira equivocada. Em contrapartida, elementos literários e históricos apontam a figura feminina como elemento essencial na formação ideológica e funcional da lírica trovadoresca, surgida nos meados do século XII, na França medieval, que influenciou, dentro do quadro europeu, a poesia italiana que, por sua vez, soube reformular a lírica amorosa (BATTAGLIA, 1957, p. 78).

Esse processo de busca pela formulação de uma poesia que pudesse não apenas imitar aquela provençal, mas que adaptada à realidade local pudesse responder aos anseios do ouvinte bem como centralizar ainda mais a figura da mulher como topos, sobretudo na poesia provençal. Nesse contexto é importante compreender as mudanças ocorridas no comportamento, na feição e imagem da figura feminina na Idade Média para então tentar apontar o referencial da mulher buscado por Dante, que apresentará a seu leitor além de uma poesia fortemente escolarizada, um modelo construído, principalmente, a partir de elementos espaciais bem alicerçados em sua cidade, Florença. A respeito disso vejamos a citação de Angiolillo:

Ma la sua fiorentinità, intesa come complesssità di contrasti e di passaggi verso il nuovo,era nel sangue, perchè tutto, nella poesia come nella logica del poeta rimanda, anche se per contrasto, alle sue origini, a Firenze. È indubbio che Firenze e la sua perduta hanno scatenato oltre modo l'immaginario dantesco; è indubbio che Firenze ha rappresentato nel suo immaginario il dualismo della città ${ }^{1}$ (ANGIOLILLO, 1994, p. 8).

\footnotetext{
${ }^{1}$ Mas a sua [de Dante] florentinidade, entendida como uma complexidade de contrastes e de passagens rumo ao novo, estava no seu sangue, pois tudo na sua poesia e na sua lógica de poeta, mesmo que contrastando com suas origens, remete Florença. Não há dúvida que Florença e a sua perda, tenha desencadeado sobremaneira, um novo modo de pensar no imaginário dantesco, bem como que Florença tenha representado no seu imaginário o dualismo da cidade. (Tradução nossa).
} 
Florença, como podemos perceber, é para o poeta um lugar de profunda inspiração, sendo que sua ausência provoca um constante desejo de retorno, após o exílio do poeta. É na sua Florença que o poeta encontra sua musa Beatriz, novo símbolo representativo feminino que condicionará outras representações na poesia. Traçar um perfil da mulher nos anos antecedentes e subsequentes ao período em que viveu o poeta florentino exige uma busca historiográfica sobre o momento da elaboração de um olhar misógino. Todavia, é necessário, primeiramente, a apresentação de uma mulher real, explicada historicamente e que possa nos apontar um caminho para os modelos poéticos.

O olhar que via e guiava os outros olhares, no período em estudo, era o masculino que carregado da ideologia cristã, e por isso temeroso ou mesmo avesso à presença feminina nas relações de cunho político-social, buscava intimidar qualquer manifestação imaginada por esta. Toda sorte oriunda da ideologia cristã sustentada pela interpretação dialética dos padres da Igreja, no que diz respeito à mulher, tem a sustentação na Bíblia, que na Idade Média era a luz da crescente e temida cristandade. Em linhas gerais, qualquer justificativa que tivesse aporte na sagrada escritura revelava uma verdade absoluta, desse modo a mulher era coroada ou mesmo rotulada como a portadora do pecado que, por natureza, afasta 0 homem de Deus. Sobre isso, Duby compartilha do mesmo ponto de vista defendido por Godofredo de Vedôme, ao afirmar que:

questo sesso ha avvelenato il nostro primo genitore, che era anche suo marito e suo padre, ha istrangolato Giovanni Battista, portato a morte il coraggioso Sansone. In certo qual modo, ha ucciso anche il Salvatore, perchè se non fosse stato necessario per il suo peccato, nostro Signore non avrebbe avuto bisogno di morire. Maledetto sia questo sesso in cui non vi è nè timore, nè bontà, nè amicizia e di cui bisogna diffidare più quando è amato che quando è odiato ${ }^{2}$. (DUBY, 2008, p.157)

Essa mácula da desordem, tabernáculo do demônio, tem fundamento na anulação do prazer, criado pela Igreja para justificar a distância dos clérigos aos

\footnotetext{
${ }^{2}$ Este sexo envenenou o nosso primeiro pai, que era também seu marido e seu pai, estrangulou João Batista, levou à morte o corajoso Sansão. De certo modo, assassinou também o Salvador, porque se não tivesse sido necessário por tal pecado, nosso Senhor não teria tido necessidade de morrer. Maldito seja este sexo no qual não há nem temor, nem bondade, nem amizade, e do qual é preciso desconfiar mais quando é amado que quando é odiado. (Tradução nossa).
} 
prazeres da carne, fundamentando tudo isso a partir das homilias e epístolas dirigidas aos seus fiéis (DUBY, 2008 p. 23).

Como lemos em Duby, Vedome buscava convencer seus monges de que para se aproximarem de Deus era preciso afastarem-se dos prazeres da carne, remetendo à figura da mulher, principal caminho para a perdição. Nesse contexto os monges deveriam refletir sobre a superficial beleza feminina, sinônimo de engano e uma das piores ilusões do homem.

O mesmo caminho aponta Duby (2009, p.29) ao analisar Oddone de Cluny (942), amparado nas homilias de João Crisóstamo (407 D.C.) contra Eva, cujo discurso evidenciava, junto aos seus seguidores, a não observação dos prazeres da carne, exortando os fiéis a refletirem que a beleza do corpo reside unicamente na superfície da pele, cuja "função" é ocultar a verdadeira essência feminina, capaz de causar náuseas àquele que consegui ver além dessa pele.

Esse jogo retórico encontra sustentação na literatura médica vigente acerca da estrutura interna do corpo humano, conhecido a partir do "corpora" das obras de Gynaecia di Sorano di Éfeso (século I), assim como da obra de Nemésio de Emesa (IV d.C), traduzida por Afonso de Salerno em meados do século XI, o De Natura Hominis $^{3}$. Importante ressaltar que são obras seguidas de comentários dos escolásticos sempre detentores da palavra, ou seja, "gestores do real", construtores do perfil feminino.

No Decretum Gratiani, uma compilação de textos de direito canônico datados do século XII em que se lê expressamente: é notável que a mulher deva estar sempre subordinada ao marido e que diante deste não há nenhuma autoridade, a exemplo de ensinar fica patente a ideia de dependência da mulher em relação ao homem.

Os séculos anteriores ao XIII são de intensa e fervorosa aversão às mulheres, culminando com a criação de mosteiros, que traduzem a necessidade de uma vida reclusa, preenchida pela oração e vigília propostas por São Bento (480-

\footnotetext{
${ }^{3}$ II De natura hominibus di Nemesio di Emesa (IV secolo d.c) manual que trasmite o pensamento médico medieval. As produções mais numerosas e mais ricas no que concerne à reflexão científica da época e que são atribuídas às atividades dos médicos da escola de Salerno, graças às traduções de Constantino, o africano, efetuadas na segunda metade do século XI.
} 
547), e posteriormente seguidas por homens como São Francisco de Assis (11821226). Tais medidas selam e contribuem para o olhar misógino ao sexo feminino, sendo que as ordens mendicantes serão pensadas como forma de esquivo ao contato sexual.

Este breve estudo sobre a fisionomia histórica feminina tem como recorte os séculos chamados pela historiografia de Idade Média. Devido à grandeza temporal limitaremos tal estudo ao período que corresponde didaticamente à Alta Idade Média, importante para a compreensão do nascimento ideológico do que posteriormente contribuiria na reconstrução e inserção da mulher nas diferentes relações sociais.

O que leva à concretização desse olhar misógino, no período em estudo, é sem dúvida, o discurso continuado seja pelos padres da lgreja, ou pelos juristas, filósofos e teólogos, que podem ser vistos como construtores de opinião. Essa discussão imprime certo encaixe, ou seja, para a mulher devem-se construir espaços de limitação já que o seu passado, sempre pautado na orientação bíblica, não é de perto tão bom como ressalta Losandro:

Na natureza particular, a fêmea é um ser deficiente e falho. Porque a virtude ativa, que está no sêmen do macho, tende a produzir um ser perfeito semelhante a si, do sexo masculino. Mas o fato de ser a fêmea a gerada provém da debilidade da virtude ativa, ou alguma indisposição da matéria; ou ainda, de alguma transmutação extrínseca, por exemplo, dos ventos austrais, que são úmidos, como diz Aristóteles. Mas, por comparação com a natureza universal, a fêmea é um ser falho, pois está destinada, por intenção da natureza, à obra da geração. Ora, a intenção da natureza universal depende de Deus, universal autor da mesma. Por isso na instituição desta produziu não só o macho, mas também a fêmea. (LOSANDRO, 2008, p.79)

O advento mariano que surge para desfazer toda a mácula feminina ao longo da exegese sobre Eva faz renascer a possibilidade de redenção ocorrida pela oração, penitência e arrependimento, que atribuem nova fisionomia à mulher. A ideia de associar a virgindade ao prazer brota com frequência nos diálogos dos grandes pensadores eclesiásticos a fim de justificar a negação e afastamento do corpo feminino, bem como a tradução de manuais de anatomia colocarão em evidência o 
estudo dos órgãos internos da mulher como uma forma para encontrar respostas que atestem o olhar misógino (BERTINI, 2008 p. 87).

A apresentação do corpo da mulher é seguida pela ideia de aproximação do pecado, informações sempre advindas de interpretações bíblicas, capazes de confirmar a ideia da culpabilidade do prazer, buscando aprofundar a discussão sobre a sexualidade, como afirma Duby (2009, p.76), de modo que a Igreja procura a regulamentação do matrimônio.

O matrimônio torna-se uma espécie de aliado, da Igreja no século XII, na contenção do que era considerado uma grande desordem sexual, assim como na união de famílias e na possibilidade de uma procriação ordenada, fator que trará à mulher um papel de destaque, tanto simbólico, ao ser equiparado à Virgem Maria, como social - ao garantir o ordenamento familiar.

A ideia de superioridade masculina, no que se refere à força e mesmo ao espaço social, será uma orientação da leitura corrente da filosofia neo-aristotélica, que impõe ao macho a centralidade familiar. Nesse contexto cabe à mulher a realização de tarefas e funções que não se assemelhem àquelas masculinas, no que diz respeito ao poder, sendo necessária a escolha de espaços diferentes dos ocupados pelo homem, notadamente o âmbito doméstico.

É possível traçar e perceber as mudanças e continuidades da noção de vivência feminina, ocorridas no período em estudo, dominado sempre pelo olhar clerical e submetido, ainda, à filosofia advinda do seio da Igreja.

Desse modo, traçar uma história da mulher no século de Dante, tentando perceber a influência dessa na sua obra, exige um estudo da concepção de mulher pintado pela Igreja, que, por sua vez, será realizado através do olhar evidentemente histórico. Só assim, quiçá, poderá se chegar à compreensão da reconstrução da mulher na lírica medieval, e, sobretudo, naquela dantesca.

A Igreja funda ao longo dos séculos estereótipos como, Maria redentora, imaculada progenitora, com o intento de sobrepô-los à ideia de Eva portadora do pecado original. Importante ressaltar que a fundação do Período Mariano contribui na apresentação de uma mulher que fuja ao "rótulo" de pecadora, assim Maria 
redime Eva. Esta cede espaço, no palco das representações, para Maria, mulher ideal, que conduzirá a outra, a pecadora, ao leito do esquecimento.

Maria, como símbolo de redenção, responsável pela vinda do Salvador sem perda da virgindade, que para a lgreja era porta de entrada para os prazeres carnais, é fortemente proclamada no período monástico, justamente época em que nasce e cresce a intensa devoção à Virgem Imaculada. Surge assim, o período de Grande Fluxo Mariano - o século XIII, um intervalo de esplendor, e como bem afirma Jacques Dalarum (2009, p. 48) è nella tensione verso la Vergine che la mistica medioevale prende lo slancio ${ }^{4}$.

A vida monástica proporcionará intenso culto a Maria, enfatizando uma ideologia que encontra na clausura uma forma de dedicação e distância dos prazeres carnais, tão difundidos no período em análise e atestados, ainda, por estudos de historiografia, que apresentam modos e subterfúgios para uma intensa contenção sexual através da busca do claustro no período merovíngio, apontando que isto ocorria por motivos como: medo da gravidez e do parto, e, muitas vezes, pelo comportamento violento do marido. Como aponta Suzanne Fonay (2009, p.228) um escritor anônimo da vida de Santa Sigolena di Albi conta que ela ofereceu todos os bens ao marido em troca da liberdade.

A compreensão de uma sexualidade vivida sob tais medidas radicais e castrativas apresentam parâmetros somente pautados na voz masculina, muitas vezes ofensiva. Em Libro di Buoni Costumi, obra de um mercante Fiorentino, encontramos o seguinte comentário sobre a mulher: "Buon cavallo e mal cavallo vuole sprone; buona donna e mala donna vuol signore, e tale bastone,5. O uso de ditos que só serviam para concretizar o espaço de submissão é frequente nos documentos que apresentam referências às mulheres.

Poucas mulheres serão poupadas, e a estas se recorre de modo que 0 trabalho possa apresentar um modelo histórico para ser aproveitado como fonte de entendimento do quadro da poesia italiana ora em estudo.

\footnotetext{
${ }^{4}$ É na tensão em direção à Virgem que a mística medieval ganha impulso. (Tradução nossa).

5 Bom cavalo e mau cavalo requer esporas; boa mulher e uma má mulher quer um senhor e seu bastão. Paolo da Certaldo, Libro di Buoni Costumi, no 209, in Mercanti Scrittori, ed. V. Branca, Milano 1986, p.43.
} 
Não há autonomia feminina nos anos que compõe a ldade Média (X D.C. a XV D.C.); dos homens se conhecem seus nomes, seus espaços, suas funções na sociedade (se padres, leigos, nobres, etc.); no que diz respeito à mulher, contam os documentos clericais,

Le loro parole alle donne godono del privilegio di essere state scritte, in latino dagli uomini di chiesa, in volgare dai laici, e sono arrivate fino a noi organizzate nelle forme tradizionali del discorso normativo, la predica, il trattato morale e pedagogico. (THOMASSET, 2009, p. 58). ${ }^{6}$

A mulher para sobreviver diante da total submissão masculina se defende de maneira a colocar-se em espaços sociais, ou seja, cria espaços de sobrevivência, por isso, a casa e o cuidado para com os filhos são resultado da ideologia gestada. Uma série de escritos oriundos da voz masculina vai comentar, a seu modo, o esquema de funções estritamente direcionado à mulher. Esses critérios vão definir o estado de classificação feminina que, por sua vez, determinará o comportamento que cada uma vai ter dentro desse quadro de inserção comportamental e social do período em estudo.

O casamento como ideia pensada para conter o forte impulso sexual e mais ainda para unir famílias importantes, mantendo a continuidade dos ramos familiares, vai estabelecer um critério de escolha, no qual o homem ou a família dele selecionará uma mulher que tenha o perfil para manter o sangue e a linhagem; isso era condição fundamental na época. A discussão sobre tais critérios no processo de seleção da mulher mostra que a boa escolha pressupunha uma vida matrimonial acertada, porém essa forma de decisão deixa de lado a vontade feminina que pouco ou nada interfere nesse processo. A este propósito vejamos as palavras de Georges Duby:

Quado pigli moglie, guarda bene ch'ella sia nata di buono padre e di buona madre, e che l'avola sia suta donna di buona fama, ché rade volte fia buona la madre de la fanciulla e l'avola, che la fanciulla fia rea. Anche, guarda molto che la moglie che pigli non sia nata di schiatta di malatti, o di tisichi, o di gavinosi, o di pazzi, o di tignosi, o di gottosi, ché spesse volte avverrà che' figliuogli, che di lei

\footnotetext{
${ }^{6}$ As palavras deles para as mulheres gozam do privilegio de terem sido escritas em latim pelos homens da Igreja, em vulgar pelos leigos e chegaram até nós organizados nas formas tradicionais do discurso normativo: a pregação, o tratado moral e o tratado pedagógico. (Tradução nossa).
} 
nasceranno, sentiranno, o tutti, o alcuno, d'alcuno de' detti vizi e magagne. Anche guata a pigliare donna savia e di bel viso, sì n'avrai be' figliuoli; e se fia savia, fia buona. ${ }^{7}$ (DUBY, 2009, 146)

A escolha de modelos bem delineados apresenta de modo geral uma relação que tem correspondência com àquela da estrutura da sociedade feudal. A lírica amorosa sofre essa influência graças às regras oriundas desta sociedade, e que devem ser seguidas para a continuação de um modelo comportamental, confluindo para as mesmas exigências de comportamento feminino, conforme já explicado.

Esses modelos serão direcionados a mulheres específicas, com atributos preestabelecidos de comportamento e imagem, bem como na sua colocação em espaços que as diferenciassem de modelos periféricos ${ }^{8}$, conforme destaca Casagrande:

Nel passaggio dalla donna alle "donne" si produce un sconcerto, un momento di indecisione e perplessità, in cui ognuno cerca e sperimenta soluzioni più o meno efficaci, più o meno articolate. In questa fase di sperimentazione, destinata a durare per tutto il secolo XIII, le donne invadono numerose e diverse i testi pastorali e didattici che stentano a trovare un criterio unanime per individuare $\mathrm{e}$ classificare l'uditorio femminile a cui si rivolgono ${ }^{9}$ ( CASAGRANDE, 2009, p. 91).

\footnotetext{
${ }^{7}$ Quando escolher sua mulher, observe bem se ela nasceu de um pai bom e de um boa mãe, também se sua avó tenha tido boa fama, observe também se a mãe da mulher que escolher seja boa, ou também se for criada com a avó o mesmo fazes, observe se ela foi boa, atente também se a sua geração não provem de linhagem doentia, a exemplos de tísicos, perebentos, doentes mentais, de couro cabeludo cheios de seborreia, com veias inflamadas, pois que pode ocorrer de seus filhos herdarem todas as doenças descritas. Se não souber escolher sua mulher, procura enfim uma mulher sábia e de bela aparência assim terá belos filhos.

${ }^{8}$ A noção de modelo periférico é alusivo a uma ideia de mulher que não se encaixa nos modelos encontrados para fugir à comparação com Eva, sabe-se que por mais que no culto mariano perdurasse a noção de inferioridade e transgressão ainda era comum, por isso surge uma terceira figura, Madalena, que ainda maculada pela noção de pecado só será redimida pela oração seguida do reconhecimento da culpa. ( Duby, 2009. p.41).

${ }^{9} \mathrm{Na}$ passagem da mulher às mulheres se produz um desconcerto, um momento de indecisão e perplexidade, em que cada um procura e experimenta soluções mais ou menos eficazes, mais ou menos articuladas. Nessa fase de experimentação que duraria por todo o século XIII. Numerosas e diversas mulheres invadem os textos pastorais e didáticos que buscam encontrar um critério unânime para individuar e classificar o auditório feminino, para o qual direcionava seu discurso. (Tradução nossa).
} 


\title{
2.1 A FEIÇÃO E O COMPORTAMENTO DA MULHER MEDIEVAL
}

Fixando as escrituras sagradas como referencial no Ocidente, podemos dizer que a história da mulher é secundária, ou seja, é contada após a narração da história masculina. Na exegese bíblica, a mulher é uma parte do homem uma vez que é retirada da costela deste, sendo moldada com o intuito de proporcionar companhia ao homem. Tal premissa justifica-se através da seguinte passagem da Bíblia:

\begin{abstract}
Então o Senhor Deus fez vir sobre o homem um profundo sono, e ele adormeceu. Tirou-lhe uma das costelas e fechou o lugar com carne. Depois da costela tirada do homem, o Senhor Deus formou a mulher e apresentou-a ao homem. E o homem exclamou: "Desta vez sim, é osso dos meus ossos é carne da minha carne! Ela será chamada humana, porque do homem foi tirada" (GÊNESIS 2; 20-23).
\end{abstract}

A história da criação como ponto de referência para o homem ocidental vai direcionar o que ao longo dos anos é interpretado como verdade absoluta, isto é, a mulher como ser inferior e dependente.

No período Medieval, por exemplo, a mulher será vítima de uma leitura misógina, como pode ser notado no episódio bíblico da criação e da queda do homem que apresenta grande peso na interpretação exegética do homem medieval, que através desse modelo interpretativo moldará o percurso da história do sexo feminino.

A história da criação e a queda do homem, tendo Eva como ser responsável por tal desgraça, legará à mulher grandes marcas ao longo dos tempos, sendo que o pensamento teológico católico implicará, como ressalta Losandro (2008, p. 68), na utilização desta figura - com tudo o que nela inclui - para referenciar a mulher em geral, já que seu papel na queda será a primeira e exclusiva causa da construção imagética deste ser.

A interpretação cristã em torno dessa passagem bíblica contribuirá sobremaneira para a noção de inferioridade do universo feminino. Ambrosio de Milão (397 D.C.) afirma que a mulher é que foi a autora da falta para o homem, não 
o homem para a mulher. Concomitante a essa mesma ideologia, Tertuliano (223 D.C.) pinta a figura feminina como um ser capaz de aproximar o homem da serpente, que metaforicamente seria a representação do diabo. Vejamos a posição de Ambrosio de Milão descrita por Dalarun:

Não sabes tu que és Eva, tu também? A sentença de Deus tem ainda hoje todo o vigor sobre esse sexo, é preciso, portanto, que a sua culpa subsista também. Tu és portadora do Diabo, tu consentiste na sua árvore, foste primeira a desertar da lei divina ${ }^{10}$. (DALARUN, 2009, 34)

A imagem da mulher como símbolo do mal perdura. Inicialmente ela exercia função de tabernáculo do Diabo, pois tinha maior propensão ao mal, sendo vítima do Diabo por excelência. Entretanto esse pensamento parece ser antitético, pois carrega consigo a ideia de ser que também traz a vida. Segundo Isidoro de Sevilha (apud DUBY, 1990, p. 39), cujas sábias etimologias constituem uma das chaves de palavras essenciais da visão clerical da mulher medieval, Eva é vae, a desgraça, mas também vita e que segundo o famoso hino Ave Maris Stella atestado a partir do século IX, em Eva lê-se o anagrama de Ave dirigido por Gabriel à nova Eva, que cede espaço à Maria, para com isso amenizar a tão profunda culpa legada a esse ser.

São Tomás de Aquino (1225-1274) na sua obra suma teológica (1265-1274) (XIII q.80 m.2) busca interpretar, através da concepção ambrosiana, o versículo do livro bíblico Gênesis (II, 21-23) que narra a criação de Eva a partir de uma costela de Adão, gestando com isso o que viria a ser a condição da dependência feminina, ou seja, a sua sujeição ao homem atestada pela Bíblia.

Além da Bíblia, afirma Bertini (2002, p.13), os textos pagãos também proliferam um olhar negativo em relação à mulher. Desse modo, inúmeros exemplos poderiam ser retirados da Bíblia, todavia, o trabalho limitar-se-á apenas à seguinte fala de São Paulo Apóstolo:

${ }^{10}$ Ambrosio de Milão, PL 14, col. 303. 
o homem não foi criado para a mulher, porém a mulher foi criada para o homem .Durante a instrução a mulher conserve o silêncio, com toda a submissão. Eu não permito que a mulher ensine ou domine o homem. Que ela conserve, pois, o silêncio. Porque primeiro foi formado Adão, depois Eva. E não foi Adão seduzido, mas a mulher que, seduzida, caiu em transgressão. Entretanto, ela será salva pela maternidade, desde que, com modéstia, permaneça na fé, no amor e na santidade ${ }^{11}$. (PAZZAGLIA, 1998. P. 26)

Essa ideia de sobreposição masculina e, consequentemente, apontamento de culpa por parte do sexo frágil, trará grandes problemas e percalços para a autonomia da mulher na Idade Média. A representação que tem como modelo a exegese cristã, cujo fundamento é usado na explicação do conceito de inferioridade feminina, será devastadora. Em contrapartida, no século XIII, o culto a Maria surge como grande oriente transformador.

Maria que gerou o Cristo e em Cristo gerou os cristãos; tais palavras ecoam como hino em direção a um período de intenso culto mariano em que a figura feminina sofrerá uma mudança de olhar, sobretudo, a partir de São Bernardo de Claraval (1090-1153), que sistematizou e difundiu o culto mariano na Idade Média. Nesse momento entra em jogo a ideia de pureza e culto à maternidade, sendo que a segunda ganhará maior espaço e exortação.

A ideia de pureza será vivenciada em Maria pela concepção virginal que é apresentada à mulher como vontade de Deus, temática recorrente nas homilias e cartas dos padres da Igreja que, em uníssono, falam de uma recompensa após a morte no que diz respeito à conservação do corpo longe da mácula do pecado.

A intensa leitura e exortação de Maria como mulher escolhida por Deus para trazer Jesus ao mundo, atrairá para o seio da Igreja, com a proliferação das ordens monásticas, mulheres que renunciaram ao casamento como opção e trancaram-se em mosteiros, simbolizando, dessa forma, a entrega da própria vida a Cristo.

No período em estudo, várias são as mulheres que vivem e constroem esse perfil; a exemplo da história de Eloísa, mulher que viveu parte da sua vida numa dualidade decisória, pois sua vida foi marcada pela entrega de seu coração a

\footnotetext{
${ }^{11}$ Carta de Paulo a Timóteo I Tm 2,9-15.
} 
Abelardo ou sua entrega a Cristo. Seu amor por Abelardo, que passa de um estágio meramente carnal para um amor espiritual, cheio de implicações filosóficas, será a marca de um novo perfil de mulher.

Ao apresentar trechos de uma das epístolas enviadas por Eloísa a seu amado Abelardo, Fumagalli (2002, pp. 124-125) argumenta que, geralmente, quem sempre fala nessas ocasiões - sobre o amor - é a mulher. Eloísa afirma que seu amor é verdadeiro, sem desejos de riqueza e de honras, de vaidade ou de sensualidade, grosso modo, é o amor fundamentado em valores do ser amado, como assim expõe Cícero em De amicitia, no qual o amor que nasce da virtude, e não pode curar-se sozinho, depende do outro em uma mistura de liberdade e escolha.

O desejo de Eloisa como mulher, inserida em um período onde a voz feminina é silenciada, mas que ousa dizer que ama, rompe as barreiras e silêncio do claustro, anunciando assim todo o seu amor por Abelardo:

Abbiamo attraversato tutte le fasi dell'amore e se in amore si può
inventare qualcosa noi lo abbiamo inventato. II piacere che
provavamo era tanto più grande perchè prima non l'avevamo
conosciuto e non ci stancavamo mai [...] aprivamo i libri, ma si
parlava più di amore che di filosofia, erano più i baci che le
spiegazioni [...] l'amore attirava i nostri occhi più sovente che la
lettura ai libri' ${ }^{12}$ (RONCARI, 2002, p. 125).

No período vivido por Eloisa e Abelardo, entregar-se a histórias de amor era perigoso. Elas eram marcadas por conflitos e frequentemente por separações brutais. Eloísa vive sobreposta ao conflito de abdicar de um desejo carnal, cedendo espaço a um conceito de amor que não prioriza o contato. Ela viveu a sua história com Abelardo sem discretio, todos que os conheceram sabiam do amor existido entre eles, mas o casal não pôde viver esse amor, pois ela havia decidido tomar o hábito, e ele, continuar no claustro. Dessa forma, só restou aos amantes a troca, ao longo do tempo, de correspondências cheias de poesia confessional e amorosa.

\footnotetext{
${ }^{12}$ Atravessamos todas as fases do amor e se sobre o amor se pode inventar alguma coisa, nós o inventamos. O prazer que provávamos era muito maior porque antes não o tínhamos conhecido e não cansávamos nunca [...] abrimos os livros, mas se falava mais de amor que de filosofia, havia muito mais beijos que explicações [...] $\mathrm{O}$ amor nos chamava mais atenção que a leitura dos livros. (Tradução nossa)
} 
Coincidentemente um século depois, no século XII, surge na França o movimento provençal que, quiçá, pode ter buscado, também na experiência amorosa de Eloísa e Abelardo, fontes para o que logo mais se estudará dentro do quadro da lírica italiana.

Não podemos nos esquecer de que, ao lado do vulto de Eloísa, temos a figura de Eleonora de Aquitânia, que consciente das suas vontades ousa contradizer a opinião masculina, deixando de lado qualquer sentimento moral e religioso, conscientizando-se, ainda, de sua condição feminina, e usando sua grande beleza para provocar o fascínio daqueles que dela se aproximavam. Prova disso, é o fato do rei Luis VII da França levá-la ao altar com treze anos,

Egli bruciava di un amore ardente per la giovincella" così almeno riferisce, mezzo secolo dopo, Guglielmo di Newburgh, uno dei monaci inglesi che, com grande abilità, riscostruivano allora la serie degli avvenimenti del tempo passato. Guglielmo aggiunge: "II desiderio del giovane capetingio fu imprigionato in uma stretta rete niente di sorprendente, tanto vive erano le gazie del corpo delle quali Eleonora era dotata ${ }^{13}$. (DUBY, 2008, 45)

O fascínio pela história de Eleonora talvez tenha confirmação na ideia de diferença, pois ela conjuga valores que se contrapõem a uma sociedade avessa à liberdade feminina - eis que surge Eleonora - duquesa, contrária a toda a política de comportamento misógino feminino do século XII (DUBY, 1995, p. 22). No destino da duquesa Eleonora só existem dois incidentes atípicos para a mulher na Idade Média: o divórcio e a sua rebeldia.

As poucas informações sobre Eleonora ressaltam uma mulher que ousou dizer "não". Mesmo com os poucos dados sobre esse vulto feminino podemos dizer que se sabe muito mais a seu respeito do que de outras mulheres de sua época. Como todas as meninas, Eleonora foi destinada a se casar aos treze anos com um

${ }^{13}$ Ele queimava de um amor ardente pela jovenzinha, assim pelo menos se referia meio século depois, Guilherme de Newburg, um dos monges ingleses que com grande habilidade reconstruiu então a série dos incidentes do tempo passado. Guilherme acrescenta: "O desejo do jovem capetíngio foi aprisionado em uma estreita rede nada surpreendente, tão vívidas eram as graças do corpo das quais Eleonora era dotada. (Tradução nossa). 
homem que não conhecia; levada da casa paterna ainda muito jovem, submetida a outros costumes e falares diversos, como fica nítido na seguinte fala de Duby:

poiché veniva da una provincia lontana, poiché il suo modo de parlare e certe sue maniere destavano curiosità, fu vista come un'intrusa dalla parentela del marito, spiata continuamente, caluniata $^{14}$ (DUBY, 2009 p. 23).

A condição atribuída ao papel da mulher ao longo da Alta Idade Média é de uma constante modificação comportamental, de um lado a imposição masculina, de outro a contestação a essa imposição por Eleonora e Eloísa, ambas em contextos diversos. Assim, deparamo-nos com diversos modelos possíveis de esclarecer o olhar da sociedade acerca desse ser conflagrado como portador do pecado original, que ao longo do tempo encontra na figura de Maria um modelo a ser seguido.

O espaço de Maria dentro da filosofia medieval cristã é bem construído, a mulher apesar da exegese acerca da queda, também participa do mistério da salvação e redenção humanas, todavia era preciso encontrar um espaço em que a mulher, quando redimida através da oração, pudesse ser referenciada, e Maria é quem intercede a seu Filho como mãe bondosa e angelical para que o Homem participe do mistério salvífico.

Em fins do século XIII e início do XIV perdura uma constante teologia da salvação, é uma época em que a preocupação preeminente era a própria salvação e a iconografia mariana ganha espaço como forma de exortação. Frugoni (1983, p. 165) destaca que esse mistério que envolve a salvação pós-morte vai gerar uma iconografia voltada a Maria que permite ver o modelo, assim como as palavras presentes na narração evangélica, como horizonte a seguir.

O modelo de intercessora e mediadora diante de Cristo dará à mulher um espaço de destaque dentro do pensamento cristão, influenciando profundamente a forma de tratamento do sexo feminino. A presença mariana na iconografia, nos afrescos, e sua lembrança no processo litúrgico trarão grandes "mudanças" ao gênero no século XIII. Maria impulsiona a virgindade; em outras palavras, o culto

${ }^{14}$ Dado que vinha de uma terra distante e com modo de falar diferente, dotada de maneiras culturais estranhas, provocava curiosidades sendo vista pelos parentes do marido como intrusa. Foi caluniada e vigiada continuadamente. (Tradução nossa) 
mariano é envolto na ideia de pureza, qualidade conquistada apenas pelas mulheres virtuosas que buscaram viver de acordo com o modelo.

$\mathrm{Na}$ busca por uma vida de doação e contenção dos próprios impulsos, as "categorias" femininas que mais puderam vivenciar o modelo mariano foram: viúvas, virgens e esposas que souberam ou tentaram de fato praticar a contenção sobre os próprios desejos sexuais. Elas são convidadas, até porque estão inseridas dentro de um espaço que tem como condição para ali estarem, à observação dessas regras. $A$ elas cabe a tarefa de direcionar o prazer somente para o momento da procriação.

Os modelos femininos, apresentados pelos pregadores e moralistas da época, constituem um modelo ao mesmo tempo reduzido e disforme, sendo que na maioria das vezes eram exortadas ou obrigadas a castrar seus instintos naturais. Tais valores foram difundidos de geração em geração e acompanharam a mulher durante longo tempo.

Certas tarefas eram direcionadas à mulher, a exemplo da oração frequente, da compostura dos gestos, da contenção ao falar, da sobriedade e da alimentação, práticas que induziam a uma educação voltada ao controle; muitas dessas orientações tinham como objetivo criar um modelo feminino capaz de controlar os seus instintos, conforme notamos no discurso de Casagrande:

No final do século XII e início do século XIII virgens, viúvas e mulheres casadas se impõem como as principais interlocutoras dos pregadores e moralistas, o sucesso dessas categorias tem como destino a duração e torna-se clamoroso, de modo que a pregação e os tratados sobre as mulheres compostos por padres e moralistas tem como critério mulheres que seguem com extrema observância a castidade (CASAGRANDE, 2002, p. 103).

Tal sucesso não exclui de modo geral a ideia de inferioridade e de submissão para com o esposo. De fato, o modelo mariano imprimirá um espaço possível no qual as mulheres possam participar das relações, se não diretamente nas decisões, influenciando, quando possível, no processo decisório da família. A figura feminina vestida de nobreza pôde participar com voz ativa na política e nos caminhos da fé. Vale lembrar que quando se fala de política no período medieval, tem-se que 
pensar, sem dúvida, na ação cristã como mediadora, quando não, como centro nos processos decisórios.

Após o intenso Período Mariano a criação das ordens monásticas femininas ganhou mais espaço e difusão. Aquelas mulheres que desejassem fugir da obrigação do matrimônio teriam como escolha a vida conventual. Não podemos nos esquecer ainda dos casos das grandes rainhas que após tornarem-se viúvas escolhiam a vida monástica como opção (FONAY, 2009, p. 226). 


\subsection{MATILDE DE CANOSSA: UM MITO FEMININO NA ITÁLIA DE DANTE}

A história da Condessa Matilde, dita Matilde de Canossa, é um exemplo magnífico, pois ilustra o perfil de mulher combativa e ousada. Dona de poderes políticos, impossíveis para sua época, sobretudo porque o período do seu domínio é misógino por excelência.

Nascida, provavelmente, em Mantova - Itália, em 1046, toda sua história confunde-se, por vezes, com sua elevação à condição de mito. Sua atuação no século XI em favor da Igreja Católica modifica o olhar sobre a condição feminina. Seus feitos a colocam no rol de figurões políticos do século XI, sendo apontada, de acordo com o professor Santunione (1996, p. 5), como o personagem feminino mítico e popular da história italiana que, desde a Idade Média, fascina e permanece vivo através das construções de rocas e catedrais, monumentos construídos para a afirmação e difusão do Cristianismo.

Reconstituir o mito da Condessa é entrar na história das possessões e poderes familiares que criaram a fisionomia político-social da Idade Média, período em que viveu Matilde. O feudalismo é o sistema político-social capaz de explicar todo o poderio "matíldico", visto que, seu poder advém dos feudos que lhe foram deixados em herança por sua família.

As possessões pertencentes a Matilde remontam ao período de arrumação e incremento patrimonial, estabelecido pelo governo feudal de Tebaldo, conde em "Reggio" e Modena, e marquês em "Mantova". A consolidação e expansão da dinastia canossana ${ }^{15}$ efetua-se de maneira mais vigorosa com Bonifácio que obtém grandes propriedades na região da Toscana, recebendo por isso, no dia 16 de março de 1032, o título de marquês e duque da região (SKIPE, 2007, p. 26).

Sem dúvida a figura de Bonifácio, pai de Matilde, foi importante na vida política italiana da primeira metade do século $\mathrm{X}$, legando a Condessa o extenso

${ }^{15}$ Qualificativo ligado à Condessa Matilde, dita Matilde de Canossa, nome atribuído à região de Canossa localizada na Emília Romana, Norte da Itália. 
poderio, resultado da sua intensa habilidade em estabelecer políticas de alianças com imperadores alemães, o que resultou no crescimento das possessões familiares herdadas pela nobre. Acerca disso esclarece melhor Badini,

Abile nell'intrecciare alleanze con gli imperati tedeschi, secondo gli obiettivi perseguiti dagli avi, fu anche capace di autonomi tentativi intesi a ricercare uno spazio politico che avrebbe consentito di portare le fortune familiari a livelli di ancor piú alto prestigio. Bonifacio aumentò il patrimonio paterno con nozze calcolate, com la sottrazione di beni alla chiesa, con altre acquisizioni più o meno lecito. ${ }^{16}$ (BADINI, 2009, p. 33)

A história da Condessa está permeada por uma série de elementos míticos, talvez pela forte personalidade, mas, sobretudo pelo seu destaque político. Diferente das outras mulheres, Matilde soube gerir com mão de ferro todo o patrimônio deixado por seu pai, situação atípica para a época. Ela sabia ler e escrever em latim e, ainda, comunicava-se em alemão medieval, italiano e francês, o que pode ser tomado como elementos justificadores, talvez, da sua afirmação no poder, segundo Spike (2007, p. 45).

O estudioso ressalta que a Condessa possuía na sua biblioteca uma vasta coleção de sermões, de escritos devocionais, comentários à carta de São Paulo, muitos desses ainda presentes na biblioteca de Mântova e nos arquivos da abadia de Nonantola-Modena. Tais informações são importantes para entender o papel de Matilde no universo feminino na Itália de Dante, bem como, para guiar a todos na compreensão de uma possível relação entre a Matilde histórica e a Matilde presente no purgatório da Divina Comédia, de Dante Alighieri, relação que será melhor discutida no terceiro capítulo desta dissertação.

Todo o processo de mitização desta mulher contestadora e política no século XI foi feita pela própria Matilde em Vita Mathildis ${ }^{17}$, uma biografia narrada a um monge de nome Donizone, certamente capelão da Condessa. Nesse texto a

\footnotetext{
${ }^{16}$ Hábil em tecer alianças com os imperadores alemães, segundo os objetivos perseguidos pelos antepassados, foi também capaz de tentativas independentes, com o intuito de procurar espaço político, permitindo levar as riquezas familiares aos níveis do mais alto prestígio. Bonifácio aumentou o patrimônio paterno com casamento arranjado e com a subtração de bens da Igreja, além de outras aquisições mais ou menos lícitas. (Tradução nossa).

${ }_{17}$ Esse poema em forma de biografia que conta a história da Condessa Matilde, tem o seu original disponível no Código Vaticano Latino de número 4922.
} 
Condessa narra todos os acontecimentos de sua vida, desde os mais simples àqueles mais sofisticados. Um dos grandes estudiosos de sua vida, o professor Michèle Spike (2007), assegura que o modelo de narração e as autoridades intelectuais presentes no texto biográfico já diz muito acerca da intenção de Matilde em deixar firmado o seu nome na história.

Vivendo em um período de forte influência do Cristianismo, Matilde desconstrói, sobretudo, no século XI, a imagem de limitação legada ao sexo feminino. Limitação que ao longo da formação do pensamento cristão trará à mulher ocidental o sentimento de inferioridade em relação ao homem. No período vivido pela Condessa de Canossa, o homem detinha o monopólio do saber e da escritura. Clérigos, sobretudo os mais eruditos, como bem aponta Dalaram (2008 p. 24) tinham o dever de pensar os rumos da humanidade, da sociedade e da Igreja, indicando a direção mais certa a ser seguida.

Diante da inquestionável existência e atuação da superioridade masculina no século XI, Matilde ocupa posto privilegiado, tece relações e consegue, por ter sido a única herdeira de Bonifácio $^{18}$, gerir de forma combativa e audaciosa os territórios deixados por seu pai. Seu envolvimento na contestação de poder entre império Romano-Germânico, liderado pela figura do Imperador Henrique IV, terceiro da dinastia Saliana, contra o Pontífice Gregório VII nos apresenta uma forte relação entre a Condessa e o Papa Gregório VII.

Essa proximidade entre a Canossa e o Papa Gregório VII deu espaço a especulações da existência de uma relação que ultrapassara a esfera fraterna. Ela, uma mulher com atributos capazes de aturdir qualquer homem, herdeira de grandes possessões feudais, além de jovem e inteligente, poderia, de fato, provocar desejos no Pontífice. O possível envolvimento entre a Condessa e o Papa marcou um grande debate dentro do corpo eclesiástico, visto que, fora a primeira relação de intimidade estabelecida entre um Papa e uma mulher jovem fora das atividades eclesiais (GOLINELLI, 1987, p. 112).

\footnotetext{
${ }^{18}$ Santunione (2001, p. 12): Com a morte de Bonifácio os territórios de seu domínio, assim como todo o seu poder, foram entregues a duas mulheres: a sua mulher Beatriz de Lorena e sua filha Matilde. O território deixado por Bonifácio tinha grandes proporções que se estendia desde os chamados pré-Alpes até o Lácio.
} 
A intervenção diplomática estabelecida pela Condessa no confronto entre 0 Imperador e o Papa, conhecido como investitura, fruto da pretensiosa decisão de Henrique IV em nomear os bispos e intervir nos processos decisórios da lgreja de Roma, faz com que Matilde exerça o papel de interventora no processo chamado de perdão de Canossa, momento em que o Imperador $^{19}$, excomungado pelo Papa, aos pés do castelo de Canossa, pede perdão.

Esse episódio histórico continua ainda vivo no imaginário do povo italiano e, ligado a outros feitos da Condessa, faz dela uma mulher muito hábil, diga-se de passagem, um grande exemplo de superação feminina para a época. Muito católica, a nobre estava sempre ao lado do Pontífice, entretanto, devia vassalagem ao Imperador Henrique IV por possuir feudos, que dentro da política do sistema feudal, exigia profunda submissão ao seu concessor, no caso, o Imperador.

A presença de Matilde em acontecimentos ligados ao Império e à Igreja concede maior destaque à nobre, cuja relação com a Igreja de Roma é muito profunda. Ela participa, por exemplo, da proclamação da primeira cruzada estabelecida pelo Papa Urbano II, vejamos:

La prima proclamazione della Prima Crociata fu fatta da Papa Urbano il sul finire dell'anno 1095 a Clermont in Francia. Mentre era in viaggio il Papa partecipò al Sinodo di Piacenza e venne informato da Matelda sul grande successo del convegno di Guatalla dove era accorsa una gran folla all'appello della Crociata. Al ritorno il Papa ritrovò Matelda che lo accompagnò a Roma passando per Lucca dove si stavano radunando i primi crociati provenienti dalla Francia (SANTUNIONE, 1996, p. 25) ${ }^{20}$.

Esse engajamento em face da difusão do Cristianismo e sua afirmação em regiões diversas faz da Condessa uma grande aliada da Igreja de Roma. Como os

${ }^{19}$ Campanini (1975, p. 123) Henrique IV chegando a Reggio pede a Matilde que confirme com o Papa, hospedado no castelo da Condessa, que deseja a absolvição. O Imperador pede à Condessa de interceder por ele junto a Gregório II com o intuito de restabelecer a paz.

${ }^{20}$ A proclamação da primeira Cruzada foi feita pelo Papa Urbano II no término do ano de 1095 em Clermont na França. Enquanto estava em viagem, o Papa participou do Sínodo de Piacenza sendo informado por Matilde sobre o grande sucesso do encontro de Guatalla, de onde havia reunido uma grande multidão favorável à Cruzada. Na volta o Papa reencontrou Matilde que o acompanhou a Roma, passando por Lucca, onde estavam se reunindo os primeiros cruzados provenientes da França. (Tradução nossa). 
feudos de Canossa estavam geograficamente próximos da Toscana, sua fama também ali difundiu-se e grandes cronistas florentinos, a exemplo de Giovanni Villani (1276-1348) na sua Cronaca Sopra Firenze, relataram os memoráveis feitos da Condessa de Canossa ${ }^{21}$. A atuação de Matilde é registrada pelo cronista até mesmo nas imediações da Toscana, nas construções de rocas e pontes em prol da fé cristã. Assim, a presença desse ícone feminino no imaginário e na história florentina faz-se notório em registros e relatos históricos da época como uma mulher prontamente a favor da difusão do Cristianismo, empenhada em construir espaços de culto, legando o seu patrimônio para a Igreja, já que ela não teve herdeiros.

Todavia, é importante destacar que esses relatos apresentam-se "soltos" e passíveis de contestação, pois se sabe que na Toscana, logo após a morte da Condessa, pouco ou nada se escreveu a seu respeito, talvez por questões políticas, uma vez que a Toscana do século XIII buscava sobrepor-se às outras regiões. (BENVENUTI, 1997, p. 54).

São inúmeros e frutíferos os feitos de Matilde de Canossa, desse modo discorrer, mais detalhadamente, sobre parte deles renderia uma dissertação ligada diretamente à figura dessa grande mulher da Itália de Dante, isso seria interessante, mas nos desviaríamos de nosso objetivo, o que pretendemos sucintamente aqui é evidenciar que a partir desses feitos e da sua difusão através dos relatos escritos e orais, é provável que Dante Alighieri, na Florença do século XIII, tenha tido conhecimento acerca da luta da Condessa na afirmação do Cristianismo e de seu envolvimento na contenda entre Império e Igreja.

A grande maioria dos exegetas da obra de Dante afirma que a atuação de Matilde em promover a fé cristã, assim como a sua efetiva presença nas construções de igrejas, pontes e rocas em toda a região da Lombardia e mesmo da Toscana, seriam indícios da sua elevação feita por Dante na Divina Comédia à condição de símbolo de pureza e da perfeita felicidade. O que resta compreender de fato é qual a imagem que Dante faz dessa Matilde, sendo ela ou não a Condessa de Canossa, assunto do terceiro capítulo deste trabalho.

\footnotetext{
${ }^{21} \mathrm{Na}$ sua crônica acerca da cidade de Florença, Giovanni Villanni (1991 p. 70) traça o perfil da Condessa que, sendo neta do grande Imperador Godofredo, é prometida em casamento como rezava a cultura, logo depois se torna viúva e dedica-se aos feitos voltados à Igreja de Roma, construindo rocas e mosteiros ao longo de toda a sua possessão.
} 


\section{O FEMININO EM DANTE}

O poeta Dante Alighieri nasce em Florença, no ano de 1265, período do alvorecer da lírica amorosa surgida na França do século XII, que teve particular destaque na região de Provença. $O$ amor presente nessa lírica provençal sofre, ao chegar a terras italianas, um processo de "adaptação" à realidade do país de Dante, que contribuirá e muito nesse processo. Se os franceses, tidos como criadores do jogo amoroso, deram luz a uma obra poética em que a mulher era o centro, pontochave e responsável pela criação, Dante, também merece crédito nesse processo, uma vez que coube a ele apontar o locus lírico como espaço feminino, no qual o fundamentalismo misógino imperante no universo medieval foi modificado com a lírica de angelização feminina. Desse modo, suas composições líricas certificam-nos - espaço incomum da mulher, e sua divina apresentação remete-nos à compreensão de um ser que ultrapassa o real.

Em a Divina Comédia, a mulher será apresentada, desde o seu conceito histórico até aquele modelo amadurecido dentro do que conhecemos na lírica amorosa italiana, como um ser angelical submisso à vontade de Deus; imaginar uma mulher que possa sobrepor-se a Beatriz, musa e modelo maior de representação da ideia de feminino em Dante, parece impossível visto que Beatriz conjuga valores próprios de um longo processo de experimentalismo que, por sua vez, faz nascer um conceito universalmente particular de mulher, sendo ela própria a maior representante.

Importante destacar que Beatriz não exclui os outros modelos femininos descritos por Dante; ela juntamente com outros personagens femininos descritos no universo dantesco compõem o que podemos chamar de "o essencial feminino em Dante".

Ao abrir um manual de estudo sobre Dante, adotado nas escolas italianas, encontramos o título L'amore delle donne nella Commedia, no qual o professor 
Alessandro Marchi apresenta uma pesquisa sobre o número de aparições femininas na DC, totalizando trinte e quatro vezes (MARCHI, 2009, p.808). ${ }^{22}$

A grande maioria dessas mulheres, presentes no corpus da obra, estão ligadas à luxúria, resultado da não contenção amorosa vivida por elas. Dessas, apenas oito falam, enquanto que as outras vinte e seis permanecem em silêncio, sendo citadas apenas para exemplificar e dar vida à poesia do texto.

Essas informações colocam em debate a importância da mulher em Dante, sendo que, em tese, o centro da Comédia é o encontro com Beatriz, musa do poeta, personagem aberto a várias possibilidades de leitura; ora mulher real evocada pela memória, ora aprecendo como uma transfiguração simbólica, fruto da modificação da lírica amorosa em terras italianas.

Como já dissemos Dante não é o precursor de uma lírica amorosa feminina, tal façanha foi realizada pela França, no século XII, que patenteia o nascimento de um modelo poético, na região da Provença, e que conhecemos como trovadorismo. A chegada dessa lírica amorosa na Europa vai se desenvolver a partir do vulgar, ou seja, a língua latina cede espaço à língua vulgar em determinado momento, em particular, na circulação dos textos que conhecemos hoje como literatura trovadoresca medieval, expandida e levada pelos trovadores às cortes que recebiam os cantos.

Em algumas culturas como na Europa medieval, a criação literária em vulgar tem como referência a circulação de um modelo que unido à experiência dos grandes compositores (que permaneciam como grandes leitores dos clássicos de língua latina) encontra na língua do povo uma gama de expressões oriundas dos universos mitológicos, das narrações, das memórias bárbaras e da troca das culturas de diferentes estratos sociais, elementos em partes ainda vivos no universo Europeu, e também basilares do romance e da lírica amorosa com suas técnicas de versificação e estrutura métrica que resistiram até o século $\mathrm{XX}$.

Essa nova literatura encontra terreno fértil na França, país protagonista do desenvolvimento econômico e da expansão agressiva da sociedade feudal, e

22 DC: Divina Comédia. Essas aparições, segundo Marchi (2009, p.808) estão contidas na seguinte ordem: Inferno: cantos II e V; Purgatório: cantos V, VI e XXX; Paraíso, canto III. 
caracteriza-se por apresentar-se "aberta”, em contínua transformação, muito distante de uma unidade linguística uniforme como a das literaturas modernas.

Essas literaturas - lírica amorosa nas suas diversas denominações e apresentações - darão força e divulgação às línguas em contínuo processo de modificação. Quando essas formas novas, incialmente destinadas a uma transmissão oral, passam para a escrita, o confronto com a cultura escrita latina precedente torna-se inevitável. Vale lembrar que os textos dessa nova lírica em ascensão tinham como finalidade a recitação em público, por essa razão havia uma natureza dramática, focada na voz, na oralidade, daí os ouvintes desse tipo de poesia serem seus maiores difusores.

A lírica amorosa recém-chegada em terras italianas era resultado dessa divulgação oral que ao longo do tempo se tornava escrita, favorecendo ainda mais uma possível unidade de criação. Sua modificação em território italiano deu-se especialmente na Sicília, região que no período despontara por ser um importante centro cultural, graças ao apoio de mecenas, a exemplo de Frederico II.

Para uma compressão ampla, temos que pensar em uma estruturação social marcada por diferentes poderes e controles, como por exemplo, no reino de Nápoles e da Sicília ou, ainda, no reino da Igreja, detentores de poderes conflitantes e desejosos de certa autonomia. A Igreja apoiada nas verdades bíblicas detém 0 poder; o homem medieval ao temer o discurso religioso acata as decisões vindas do clero. Desse modo todas as regiões nas quais a Igreja mantinha relação, a exemplo da Toscana, eram coagidas a tomar decisões sempre orientadas pelo poder clerical. (ASOR ROSA, 2009, p. 58).

O nascimento de um conceito feminino, distante daquele misógino da ldade Média, foi uma tarefa exclusiva da lírica amorosa, que teve como centro do jogo a mulher, matéria de uma produção literária cheia de leveza e fragilidade, sendo por isso capaz de provocar mudanças no universo masculino ${ }^{23}$. Entra em jogo a cortesia, um modelo de relação entre o homem e a mulher, surgida na Provença do século XII e também conhecida como fine amour.

\footnotetext{
${ }^{23}$ Antes do século XIII a mulher pouco aparece no espaço representativo a não ser como capaz de unir o homem ao pecado. (Dalaram, apud Le Goff, 1999, p. 24).
} 
Nesse modelo, que apresenta a relação amorosa entre homem e mulher, o personagem feminino é o centro da criação, uma "dama" (termo derivado do latim domina) que ocupava posição dominante e sua situação era a de mulher casada; por sua vez, um homem jovem, geralmente solteiro, olhava para a figura feminina atentando a atributos como: a sua cabeleira e o seu corpo escondidos, ornamentos que as tornam ainda mais belas. Todo esse jogo, assegura Duby, começava pelo olhar, sendo que a metáfora que melhor definia o que penetrava pelos olhos chegando ao coração e fazendo nascer o fogo do desejo que acendia o fogo do amor era a da flecha (DUBY, 2009, p.310).

Na lírica provençal, a relação amorosa está ligada a certa satisfação ${ }^{24}$ física; o homem pensa a todo o momento na obtenção do prazer carnal. Nesse contexto, a lírica amorosa apresentara-se como um jogo perigoso, pois a dama que o jovem desejava era geralmente a mulher do seu senhor, isso implicava muitos riscos para os amantes, conforme descreve Duby:

É in ogni caso la padrona della casa che egli frequenta. In virtù delle gerarchie che governavano allora i rapporti sociali, essa rimane effettivamente al di sopra di lui. Cosa che egli sottolinea compiendo gesti di sottomissione. S' inginocchia, prendendo la posizione del vasallo. Parla, impegna la sua fedeltà, promettendo, come un uomo ligio, di non offrire i suoi servigi altrove. Si spinge oltre: come servo della gleba, fa dono di sé ${ }^{25}$ (DUBY, 2009, p.311).

Essa relação amorosa vai nascer dentro das relações de vassalagem entre o homem e a mulher, sendo base da sociedade feudal em intenso desenvolvimento ${ }^{26}$. Todavia, interessa-nos, principalmente, apontar o surgimento desse novo modelo de comportamento poético-social entendendo como ele se define, para então compreender quais características e mudanças são efetuadas em terras italianas, nel ultimo terzo del XII secolo, essi si diffusero nelle grandi corti principesche di

\footnotetext{
${ }^{24} \mathrm{Na}$ obra O Amor No Ocidente, Denis Rougemont interpreta que a finalidade de todo jogo amoroso é a intenção sexual. As virtudes da cortesia: humildade, lealdade, respeito e fidelidade à mulher são intencionalmente voltadas para a obtenção do amor carnal. (Rougemont, 2006, p. 145).

${ }^{25}$ Essa mulher era a mulher da casa que ele (o trovador) frequentava isso em virtude da hierarquia que governava as relações sociais, essa mulher permanecia acima desse trovador, ele retribui isso com o gestos de submissão. Ajoelha-se colocando-se em posição de vassalo, empenhando sua palavra prometendo como homem fiel em não oferecer seus serviços a outras. Esforça-se muito, vai além colocando-se como servo da gleba, da-se como um presente. (Tradução nossa).

26 Tal modelo de comportamento amoroso nós conhecemos por meio dos poemas que foram elaborados para divertir a corte; os mais antigos são atribuídos a Gugliemo di Poitiers, reconhecido como o nono duque da Aquitânia e defensor dos trovadores.
} 
Normandia, di Turenna, di Champagne e di Fiandra, scivolandovi in un'altra forma letteraria, il romanzo ${ }^{27}$ (DUBY, 2009, p. 314).

Após a chegada às cortes, o modelo se difunde através de duas expressões, a provençal e a francesa, que se impõem durante longo período. Mesmo que no século XIV, com Dante Alighieri, essa forma poética ganhe notoriedade conjugando novos valores, ela continuará marcada pelas referências provençal e francesa, como defende Rougemont:

che tutta la poesia sia deriavata dei trovatori del secolo XII, è cosa di cui oggi nessuno può più dubitare, sì, fra il mille e il millecento la poesia, di qualsiasi parte fosse ungarese, spangola, portoghese, tedesca, siciliana, toscana, genovese, pisana, piccarda, fiamminga, inglese, ecc, era anzitutto linguadochiana, il che significa che il poeta, non potendo essere che trovatore, era tenuto a parlare, e se non la conosceva a impararla, la lingua dei trovatori, la quale fu sempre e soltanto il provenzale ${ }^{28}$. (ROUGEMONT, 2006, p.119)

A lírica amorosa francesa torna-se, ao longo do tempo, elemento integrante da sociedade italiana, sendo que, certamente, Dante tenha conhecido alguns textos provençais que chegaram até a Itália da sua época, como bem afirma Santangelo (1921, p.5). Tal informação pode ser confirmada também por Dante no De Vulgari Eloquentia. De fato, chegara até o poeta a biografia de Pietro d'Alvernia, um dos mais antigos trovadores da Provença, no entanto outros poetas líricos e textos importantes, que conhecemos hoje, não chegaram ao poeta da Commedia ${ }^{29}$.

Mesmo na ausência de uma referência escrita sobre as obras, realmente lidas por Dante durante o seu processo de inserção na arte del dire parole per rime, como

\footnotetext{
${ }^{27} \mathrm{Na}$ terceira metade do século XII essas (mudanças) se difundiram nas grandes cortes principescas da Normandia, de Turena, de Champanhe, e de Flandres, movendo-se em direção à uma outra forma literária, o romance. (Tradução nossa).

${ }^{28}$ Que toda poesia é fruto da criação dos trovadores do século XII é uma coisa ninguém pode duvidar, se entre o ano mil e mil e cem a poesia, de qualquer parte, quer fosse toscana, genovesa, pisana, piccarda, flamenca, inglesa e etc, era antes de tudo uma realidade em língua d'oc, o que significa que o poeta para ser trovador precisava falar a língua d'oc e se não a conhecia deveria aprender, pois toda essa poesia era sempre provençal. (Tradução nossa).

${ }_{29} \mathrm{Na}$ sua pesquisa o professor Santangelo aponta para o fato que alguns textos chegam até Dante e outros não. No confronto dos textos e das biografias provençais, juntamente com as alegações dantescas no De Vulgari Eloquentia, Convívio e da Divina Comédia, obras em que os trovadores são recordados ou representados, examinando a forma externa e também o conteúdo da Vida Nova, em confronto com le razos (texto atríbuido ao trovador Bertran de Born), possam enfim apontar as lacunas no que diz respeito à literatura d'oc. (Tradução nossa).
} 
ele mesmo declara na Vita Nuova (III 9), sabemos, a partir dos seus textos ${ }^{30}$, das possíveis fontes com as quais o poeta teve contato no período de estudo. Malato (2009, p.35) declara que após o contato com documentos dos trovadores, e de seu interesse em aprender a arte de composição, Dante passa a frequentar um grupo de jovens estudantes intelectuais e rimadores da cidade de Florença, exercitando por si mesmo o ofício de compor poemas, cuja exigência era o conhecimento das línguas em que os documentos poéticos estavam escritos.

As línguas d'oc e $d^{\prime} o i^{\beta 1}$ muito empregadas nos ambientes intelectuais da Florença do século XIV representam o início da aproximação de Dante com a poesia; a partir desse interesse ele terá contato com a figura de Brunetto Latini que se tornará seu mestre de retórica e a quem o poeta homenageará com intensa comoção no canto XV do Inferno (Inferno, XV 82-85).

Não podemos nos esquecer de que o homem do século XIII e XIV é fruto de um processo intelectual orientado pela lgreja que, nesse período, exercia grande função política. Como bem afirma Angiolillo o status quo do homem intelectual laico é coroado no alvéolo de uma fenomenologia doutrinal - sacra com uma liberdade direcionada a uma única cultura, a clássica, muito limitada e formalizada (ANGIOLILLO,1994. p., 23).

Neste contexto, a formação humanística de Dante está ligada ao modelo romano, ainda vigente em sua época, e segundo Petrocchi (1999, p. 11) os estudos feitos por Dante têm como referência os modelos educacionais da Florença do século XIII e $\mathrm{XIV}^{32}$. Esses modelos proporcionavam ao homem da época um profundo conhecimento do mundo, buscado por nosso poeta através do árduo estudo de várias ciências na Universidade de Bolonha e possivelmente em Paris, o que the proporcionou o conhecimento, sem dúvida, das produções poéticas francesas responsáveis por fazê-lo pensar a poesia como instrumento sublime capaz de transformar a humanidade. De fato, para Dante, a poesia instrumentaliza o

\footnotetext{
${ }^{30}$ A Divina Comédia, De Vulage Eloquentia, Rime, II Convìvio.

${ }^{31}$ Dante já trata das línguas de oc e oil no De Vulgare Eloquentia, ix: "O idioma que então tratamos é tríplice por isso alguns o chamam de oc, outros, oil e outros si".

${ }^{32}$ Giorgio Petrochhi (2008, p 11), a educação que Dante recebeu quando criança está ligada a um especialista nesse ramo, Doctor Puerorum. Sem dúvida ele recebera noções elementares de gramática, referência que ele cita no Convívio, II, XII, 2-4, que eram efetuadas a partir dos textos de Cícero e sobre os textos de Vírgilio, que ele amadurece com efetividade durante sua permanência em Bolonha. Também nesse processo ele leu textos de Catão de Utica e a Elegia di Arrigo de Sentimello.
} 
homem, a poesia passa a ser portadora de conhecimento e não mais de diversão, como era na Provença.

Fruto dessas reflexões, a lírica italiana nasce como lírica amorosa já consciente do papel que a mulher exerce dentro do quadro de sua composição. $O$ conceito feminino nessa poesia desenvolve com maior vigor a noção de representação, ou seja, a mulher real não participa de forma plena desse processo, pois ela não é real, em si, mas parte do discurso poético como esclarece Zancan (1998, p.7).

Nesse processo intelectual, a mulher real é apenas uma figura que permite 0 nascimento de uma nova imagem, sendo que há, por definição, o surgimento de uma maneira de tratamento ou de olhar, no que diz respeito à figura feminina, na lírica dantesca, cheia de intensa novidade.

O amor também surge como conceito de ligação exclusiva com a figura feminina, de modo que pensar a lírica amorosa é pensar na relação de profunda dependência do binômio, mulher e amor. Desse modo, pode-se dizer que a lírica amorosa é, sem dúvida, uma lírica da mulher, uma vez que, como bem destacado por Ghetti, a nova linguagem, a poética, nasce diretamente ligada à imagem feminina (GHETTI, 2010, p.38); o centro do novo discurso é o corpo, a cabeleira e os traços femininos elevados a uma condição de extrema visibilidade,

Domna, tanta vos ai preiada,

si us plaz, qu' amar me voillaz

qu'eu sui vostr'endomenjatz

car es pros et enseignada

e toz bos prez autreiaz;

per que $m$ plai vostr'amistaz

Car es em toz faiz cortesa,

$s^{\prime}$ es mos cors em vos fermaz 
plus qu'en nulla Genoesa,

per qu'er merces si m' amaz;

e poi serai meilz pagatz

que s'era mia il ciutaz

dls Genoes ${ }^{33}$

Os versos de Raimbaut de Vaqueiras, trovador importante do século XII, que em terras italianas escolhe o genovês como língua para compor os seus versos, notadamente influenciado pela lírica provençal, dão espaço a uma mulher que não tem o perfil a quem os poemas geralmente eram direcionados ${ }^{34}$.

O uso do genovês, língua privada de qualquer formulação e tradição literária, favorece o contexto cômico realístico do poema, representando uma tentativa de sedução do cavaleiro por uma menina do campo, sendo que, posteriormente, no processo de amadurecimento da lírica italiana, a elevação da condição feminina ultrapassará a condição humana.

O surgimento de uma literatura dita vulgar em terras italianas a partir da escola siciliana soa pouco produtivo e exige profunda análise, a este propósito Cortelessa (2006, p.139) aponta para vozes discordantes ao referir-se à escola siciliana como sendo responsável pelo início de uma literatura vulgar italiana. Uma dessas vozes seria, segundo Cortelessa, a de Alfredo Stussi, que publicou um cancioneiro amoroso dividido em cinco instâncias, que fora conservado em um pergaminho no arquivo histórico episcopal de Ravena, e cuja análise, segundo estudos paleográficos, demonstrou que fora escrito em um período que compreende entre 1180 e 1210, portanto antes do alvorecer da lírica siciliana. Cortelessa (2006,

\footnotetext{
${ }^{33}$ Mulher muito te pedi / se quisesse que o amor me tomasse/ que eu sou o vosso servo/ sejas valorosa e sábia e todos confirmem/ porque gosto da vossa amizade/ porque seja em todos os fatos cortês/ se o meu coração firma vos/ mas que em qualquer outra genovesa/ será uma graça para mim se me amares/ depois serei bem pago/ assim como minha cidade exterminada pelos genoveses. (Tradução nossa).

${ }^{34}$ A lírica amorosa feminina nasce dentro das relações palacianas, de modo que as primeiras poesias e o modelo de lírica pensado eram para damas, ou seja, mulheres da nobreza. Temos que pensar no que Duby (2008, p. 317) aponta como uma linha de demarcação que isolava as damas das outras mulheres.
} 
p. 139) contesta tal premissa, defendendo que a datação desses documentos pode ter sido modificada ao longo dos séculos.

Importante destacar que não havia a ideia de Estado unificado no período em estudo, e conforme afirma Asor Rosa (2009, p.58) era sumariamente impossível pensar em um Estado unificado italiano nesse período. Em outras palavras, os séculos XIII e XIV desconheciam a noção de coesão nacional e, sobretudo, cultural; Estados fragmentados formavam poderes locais quase sempre de origem italiana. Uma série de indicações documentais, a exemplo dos cancioneiros toscanos, apontam o nascimento de uma lírica vulgar em terras italianas no século XIII, certificadas nos cancioneiros Vaticano Latino com 3793 manuscritos, Palatino, com 217 e Laurenciano Rediano, com 9.

A lírica italiana inicial, ou seja, aquela siciliana, que influenciará a escola poética à qual Dante pertencerá, é fruto de uma experiência vivida na corte, em particular a corte de Frederico II. Tendo em vista questões geográficas, no que concerne à unidade territorial, a lírica em terras italianas terá variadas manifestações. Gênova no século XII despontava com uma literatura de máximo esplendor sobre todos os registros. Por outro lado, é pela Sicilia que os grandes registros e a liberdade de expressão tinham espaço, sendo com Frederico II que os processos culturais ganharam maior impulso (MALATO, 1995, p.236).

Em geral, toda produção e mesmo divulgação das composições estão ligadas aos funcionários do governo ou a figuras ligadas à estrutura administrativa que desejavam verter os textos e produções provençais à realidade siciliana. Segundo Malato, essa adaptação também foi pensada pelo imperador partícipe no processo de composição:

Frederico II na sua curiosidade imprimiu no seu reino a difusão da cultura latina que ao se encontrar com a vulgar fizera nascer importantes inovações, por isso (creio) ao se falar de uma literatura inicial italiana, tem-se o reino da Sicília e suas experiências como referência para os poetas máximos do seu esplendor. (MALATO, 1995, p.235)

A poesia siciliana está essencialmente ligada a uma função social marcada pela relação vivida dentro do ambiente da corte, desta maneira, qualquer relação 
possível terá sua justificação dentro do sistema social implantado e a mulher será elemento maior dentro do quadro dessas relações.

Nobre senhora e patroa a qual se deve servir com dedicação e vassalagem, era a máxima das relações entre rainhas e súditos do século $X$ até XIV. Tal modelo misturava-se à poesia amorosa dos trovadores e fez surgir a ideia de um pathos de distância, como uma estratégia discursiva para que a mulher imersa nessa poesia não fosse descoberta, meio encontrado por alguns trovadores provençais para manter a sua poesia e sua senhora, centro dessa poesia, em segredo.

É fato que a chegada dessa lírica em terras italianas traz consigo uma nova realidade, os textos escritos em língua d'oc e oil que circulam são absorvidos pelos difusores que intentam pensar numa recriação em língua local, ligada ao processo de mudança que essa língua ganhara ao longo do tempo. Asor Rosa (2009, p. 61) afirma que essa difusão e mudança do alto latim em latim vulgar é fruto de uma absorção de termos oriundos das esferas jurídica e administrativa ao discurso poético, o que favoreceu a sua fixação em terras italianas. Vejamos:

Come nelle altre aree geografiche del ex Impero romano, anche in Italia sono stati individuati a poco a poco documenti di varia natura, che testimoniano da un certo momento in poi la diffusione di un volgare ormai affermato nei diversi campi della vita civile e la scissione operatasi, anche al livello giuridico e amministrativo, fra quanti ancora comprendevano e scrivevano il latino e quanti, invece, potevano parlare e scrivere solo in volgare. Successivamente, nel corso del XII secolo i documenti linguistici assumono anche forma poetica: per esempio, il Ritmo Laurenziano, il Ritmo Cassinese, il Ritmo su Sant' Alessio, il Contrasto bilingue di Raimbaut de Vaqueiras. ${ }^{35}$ (ASOR ROSA, 2009, p.61)

É verdade que a língua vulgar ganhou notoriedade por meio de textos literários, entretanto a literatura amorosa, da qual tratamos nessa dissertação, em particular aquela do século XIII - século do nascimento de Dante - estava reduzida a um sistema linguístico unitário, proveniente do francês, no qual

${ }^{35}$ Como nas outras áreas geográficas do Império Romano, também na Itália foram individualizados pouco a pouco documentos de várias naturezas que testemunharam a difusão de um vulgar, já afirmado nos diversos campos da vida civil. Opera-se uma cisão, também no nível jurídico administrativo entre aqueles que falavam e escreviam em latim e aqueles que podiam escrever e compreender somente em vulgar. Sucessivamente no curso do século XII, os documentos linguísticos assumem também a forma poética: por exemplo, o ritmo laurenciano, o ritmo casinese, 0 ritmo sobre santo Alessio e o contraste linguístico de Rimbaut de Vaqueiras. (Tradução nossa). 
prevaleciam com maior notoriedade as produções ainda nas línguas d'oc e oil ${ }^{\beta 6}$ que favorecerão ao longo do tempo o nascimento de uma literatura tipicamente italiana, graças ao confronto com as literaturas nessas línguas e com aquelas já presentes nas terras que hoje denominamos Itália.

${ }^{36}$ Ferroni (2006, p. 54) afirma que no século XII a língua d'oc e a língua d'oil dão lugar a uma produção literária riquíssima, a língua italiana apresenta pequenos fragmentos desta produção. No decorrer do século XIII a literatura italiana ganhará notável valor expressivo, mas ainda permanecendo reduzida se comparada àquela em língua francesa (esta menos capaz de experimentar inovações), a partir de Dante veremos um grande alvorecer de novas experimentações. (Tradução nossa). 


\subsection{DANTE E O DOCE ESTILO NOVO}

O doce estilo novo, escola aperfeiçoada por Dante e seus amigos, apresenta uma notável modificação estilística que diferenciou sobremaneira o tratamento da mulher. Tal movimento é importante por renovar a forma de produção poética, atribuindo uma nova imagem ao conceito feminino na poesia, sendo que esse amadurecimento, fruto de grande e intensa busca poética, o exortara a pensar numa elevação intelectual máxima. No dolce stil nuovo diferente da poesia siciliana e daquela de Buonagiunta da Lucca, há uma espiritualidade elevada e um doutrinarismo que evidentemente aponta a nova forma de introduzir a mulher dentro do quadro poético, conforme palavras de Valli (1994, p. 162).

Os momentos de correspondências com Guido e Dante da Maiano sinalizam um processo ainda marcado pelo experimentalismo poético, diverso de a Vita Nuova, composta por um conjunto de 25 sonetos, 4 canções, 1 balada e 1 estância de canção, chamada por Sanguinetti (1999, p. ix) de itinerário autobiográfico, e importante por apresentar a síntese dantesca do mais alto momento do seu experimentalismo que culmina na grande inovação, ou seja, no dolce "stil nuovo".

A veia estilnovista de Dante tem raízes na poesia de Guido Cavalcanti (12351276), cujo pensamento acompanhará nosso poeta de forma visceral, principalmente, em sua fase lírica. Importante destacar que o interesse da crítica acerca da relação Dante e Guido Cavalcanti pauta-se em uma curiosidade biográfica de cunho temático e conceitual entre os dois personagens de maior relevo no quadro da cultura italiana do século XIII.

Essa poesia, que desponta como nova portadora de um estilo próprio, encontra fundamento nas experiências poéticas de Guido Guinizelli, que pode ser visto como precursor do estilo. O crítico Auerbach (2009, p.24) indica que além de ser o fundador dessa poesia estilnovista italiana, Guinizzelli criou o primeiro movimento literário com características do que é moderno. Na celebre canção Al cor gentil rempia sempre amore, a utilização dos estilnovistas a partir da relação entre amor e cor gentile, presente na poesia de Guinizelli, torna-se um verdadeiro manifesto de acordo Ferroni (2006, p.147). 
O debate em jogo nessa nova maneira de poetar é a solidariedade e o vínculo que passam a ter o amor e a gentileza, que se tornam, por sua vez, uma mesma substância. Nessa perspectiva, a experiência poética de Guido Guinizelli foi importante na construção da veia poética que Dante passou a seguir, interpondo elementos de renovação e amplificação.

Deve-se reconhecer que alguns termos "guinizelianos" fazem-se presentes na poesia de Dante, mesmo na sua fase de melhor produção artística, ou seja, a da composição da Divina Comédia. Essa nova lírica, fruto de um novo estilo, rejeita, no plano fonético, sons ásperos para dar espaço a uma poesia mais doce, será retomada logo nos primeiros cantos do inferno dantesco, e servem como exemplificação das vicissitudes amorosas de Francesca e Paulo, (Amor, ch' al cor gentil ratto s' apprende (Inferno, V, 100)), seguindo a mesma linguagem guinizeliana em Foco d'amore in gentil cor s'aprende (Rime, Guido Guinizelli).

A poesia elaborada por Dante é fruto de um longo processo de amadurecimento e está intimamente ligada aos grandes e pontuais acontecimentos históricos da sua vida, bem como de marcas temporais. Sua lírica, desse modo, busca continuamente, num processo evolutivo, uma ideia de perfeição alegórica. Dante é de fato um experimentador, sua veia inovadora, dentro da arte di dire parole per rime, conduz a lírica italiana a uma vanguarda.

No que diz respeito à mulher, há uma mudança da visão poética feminina em Dante, que se baseia na relação amorosa, ou seja, é o amor o argumento utilizado pelo poeta para justificar esse processo de modificação. Em l' mi son un che, quando Amor mi spira, noto, e a quel modo ch'e' ditta dentro vo significando (Purgatorio, XXIV, 52-54) ${ }^{37}$ o poeta ressalta que seu processo de criação está baseado na doutrina amorosa, elemento fundamental da sua lírica.

A escola da qual tratamos, o doce estilo novo, concentrou-se em torno de seis, no máximo, sete poetas distribuídos de forma desigual entre as duas cidades da Itália central, ou seja, Bolonha e Florença, onde, naquele tempo, florescia a poesia lírica. Guido Guinizelli (1235-76) viveu em Bolonha e foi, para Dante, um dos primeiros a inovar dentro do quadro de composição, além de ser um precursor na

${ }^{37}$ Esse sou eu que/ quando me inspira Amor/ o noto/ e desse modo/ que dentro dita/ vou significando. (Tradução nossa). 
maneira e nos temas dessa escola. Já em Florença encontravam-se quase todos os outros poetas: Guido Cavalcanti ${ }^{38}$ (1258-1300), Lapo Gianni, Gianni Alfani, Dino Frescolbaldi.

Desse grupo, as personalidades mais relevantes, dentro do universo de composição da escola estilnovista, foram: Guinizelli, Cavalcanti, Cino da Pistoia e Dante, todos juristas de profissão ${ }^{39}$ e nobres da Florença do século XIV, dado que nos ajuda no processo de compreensão dessa poética que se apresentava ainda aristocrática.

Importante destacar que o processo de inovação dessa lírica amorosa feminina passa pelo filtro de certa tradição, isto é, o de mímeses, que ganha força e espaço nesse fazer. Segundo Auerbach (Apud CANDIDO, 1946, p.107) esse processo de mimeses tem como propósito refletir sobre a representação da realidade na literatura ocidental, promovendo a problematização do conceito de realidade, sendo que nessa perspectiva o poeta encontra a liberdade para dizer algo que é apenas espelho, que reflete uma ideia, podendo não corresponder ao material verdadeiro, dessa forma, a poesia passa a vestir-se da concepção filosófica para apresentar uma nova realidade. Aristóteles na Poetica, diz que la poesia è materia piú filosofica e elevata della storia, la poesia infatti tratta specialmente l'universale. (ARISTOTELE, 2009, p.23).

Dante e seus amigos fundadores dessa "escola" conheciam bem 0 pensamento filosófico clássico, fruto das traduções medievais que no século XIII difundiu, por exemplo, textos de Aristóteles ${ }^{40}$, assim como glosas de filósofos da cultura latina medieval a exemplo de Arrigo da Santimelo e Boécio, que é citado

\footnotetext{
${ }^{38}$ Malato (1999, p. 12) aponta que Dante e Guido estreitam um grande laço de amizade, sendo que os dois tornam-se grandes expoentes da poesia italiana nos fins do século XIII e começo do XIV. Este laço de amizade foi profícuo de correspondências poéticas, podemos apontar o primeiro soneto que Dante escreve: A ciascuna'alma presa e gentil core (Vida Nova, III, Rime, I) a qual Guido responde com: Vedeste, al mio parere, onne valore (Dante, Rime, II; Guido, Rime, XLVII a-b)

${ }^{39}$ Alberto Asor Rosa (2009 p 106): Há uma forte semelhança no que diz respeito aos participantes do movimento, grande número deles pertenciam às profissões, que, como já dissemos várias vezes, representaram uma das classes mais importantes da vida municipal do tempo de Dante. Guinizelli foi juiz; Lapo, magistrado; Cino da Pistoia, um famoso professor de doutrina jurídica. (Tradução nossa).

${ }_{40}$ Spina (1995, p. 48) Os textos da poética de Aristóteles que chegaram até nós apresentam, como fontes manuscritos, o Riccardianuns 46 e o Parisinus 1741, este último datável do sec. X ou XII, e considerado por Jean Vahlen como a única fonte, da qual teriam derivado os 17 manuscritos que se conhecem.
} 
várias vezes por Dante ${ }^{41}$ como modelo para os estudos das sentenças, bem como, exemplo da ideia de uma personificação conceitual da figura feminina.

Em sua obra Consolação Filosófica, Boécio personifica a filosofia na figura de uma bela dama de meia-idade, a mesma dama que aparecera a Sócrates no Crito de Platão e que ajudara outros mártires da filosofia, nomeadamente, Anaxágoras e Sêneca, a construírem seus discursos (LUSCOMBRE, 1997, p.35).

O movimento estilnovista buscava justificativa para o processo de criação poética na filosofia, transformando-a, aliás, em importante elemento de composição artística. Os poetas tinham uma noção segura desse processo, que ao longo do tempo exigia componentes que pudessem enriquecê-la, sendo que tais componentes são chamados por Asor Rosa (2009, p.123) de elementos reflexivos e racionais que produzem uma poesia nova estilisticamente metrificada.

A tradição da sabedoria personificada em uma senhora, por exemplo, é um fator filosófico dentro desse quadro de composição. Para Valli (1994, p.170) tal dado constitui-se em uma realidade anterior que compõe a lógica do pensamento da Vida Nova e cujos místicos persianos são representações de imagens místicas do amor e da mulher.

Essa ideia místico-filosófica, introduzida dentro da poesia, é para a escola estilnovista uma possibilidade de distanciar-se da imagem de um feminino real, que será núcleo de toda poesia lírica presente nas composições trovadorescas provençais. Assim, a mulher será elemento central, figura imersa na representação filosófica,

(...) lo secondo verso intendere sofficientemente, infino a quella parte dove dice: "Questi mi face una donna guardare". Ove si vuole sapere che questa donna è la Filosofia; la quale veramente è donna piena di dolcezza, ornata d'onestade, mirabile di savere, gloriosa di libertade, sì come nel terzo trattato, dove la sua nobilitade si tratterà, fia manifesto. (Convivio, Dante II,cap.XV) ${ }^{42}$.

\footnotetext{
${ }^{41}$ Todavia, depois de muito tempo, a minha mente, que se preocupava em resolver e prover, dado que nem a minha consolação ou de outrém valesse, e retornasse ela ao modo de que alguém a pudesse consolar e retornava à maneira de já consolado, pudesse a ela consolar. E coloquei-me a ler aquele livro de Boécio que é desconhecido de muitos, o qual, ruim e cativo, o consolou. (Convívio, Tratado; Il cap, xii) (Tradução nossa).

42 Podemos compreender suficientemente o segundo verso, naquela parte que diz: "Estes me fez uma mulher olhar". Onde esta mulher é a filosofia, a qual é verdadeiramente uma mulher cheia de
} 
O processo ocorrido com a poesia, dentro do grupo dos estilnovistas, conduz a arte de produção poética bem como, e com essa a sua matéria inspiradora, ou seja, a mulher ${ }^{43}$, a uma condição de eterno centro. Importante ressaltar que a partir desse modelo os escritores serão aglomerados em torno de um grupo que ficará conhecido como fedeli d'amore; os poetas, desse círculo, não estavam em busca de uma produção que atingisse uma determinada classe social, a exemplo dos sicilianos que produziram uma poesia em torno de uma corte régia ou dos sículostoscanos que tinham como base para a produção um contexto comunal, como bem pontua Ferroni (2002, p.146).

Eles desejavam entender, primeiramente, a experiência poética e amorosa como um valor absoluto e por isso reuniam-se em torno de um objetivo: a paixão literária. Desse modo, é através desse modelo de produção que a poesia se desvincula da classe social e os valores espirituais e literários se dissociam do papel social.

O amor ${ }^{44}$ é outro conceito recorrente dentro do quadro de composição dos poetas do doce estilo novo, sendo que os novos valores e a paixão meramente literária, no ato de compor, fazem surgir uma série de correspondências poéticas cuja função era introduzir no conceito amoroso um aspecto discursivo filosófico. $O$ mesmo conceito que Dante indica frequentemente no corpus de sua obra e que corresponde às suas trocas poéticas com os seus amigos, dando-nos a indicação de

doçura, ornada de honestidade, mirável de saber e gloriosa pela liberdade. Assim como no terceiro tratado, onde sua nobreza se manifesta. (Tradução nossa).

${ }^{43}$ De Sanctis (1956, p. 28) A memória da nossa primeira idade, aquela literária, nos permite também sentir uma ideia de mulher imersa na pureza e onipresença: o universo é a mulher, e assim foi no início da sociedade moderna na Alemanha, na França, na Provença, na Espanha e na Itália. A história foi feita a partir desta imagem, a feminina. Troianos e romanos eram concebidos como cavaleiros errantes, assim como árabes, saracenos, turcos e saladinos. Paris e Elena, Príamo e Tisbe, são heróis de romances como Tristão e Isolda, Lancelote e Ginevra.

${ }^{44}$ Villani $(2008$, p. 85$)$ na realidade, a questão do amor, dominante na problemática existencial, angustia os poetas italianos do século XIII. Centro de um debate contraditório e irresolúvel, ancorado de um lado aos postulados de Andrea Capelano, geralmente acolhidos malgrado pela condenação, o amor se reduz substancialmente aos seus termos mais elementares que são a satisfação dos instintos sexuais e a resposta imediata a um impulso puramente natural, ligado aos poucos ao senso da visão que culmina com a beleza do corpo e o prazer, que por ventura desponta dessa relação, do outro lado a ortodoxia moral e os preceitos religiosos nos quais se reconhece a obrigação, pelo menos formal, requerendo um substancial respeito. 
uma poesia impregnada de palavras misteriosas, cheias de ornamentos racionais e difíceis de compreender, conforme notamos em seus versos:

\author{
Savete giudicar vostra ragione, \\ o om che pregio di saver portate, \\ per che, vitando aver con voi quistione, \\ com so risponde a le parole ornate. ${ }^{45}$ \\ (Rime, I,i-iv)
}

As rimas da escola estilnovista apresentavam-se cheias de palavras misteriosas, particularizando um grupo de poetas que usavam a palavra de forma dupla; o ornamento acima descrito por Alighieri foi artifício bastante utilizado pelos poetas florentinos reunidos em torno de trocas poéticas amorosas.

O processo proposto por Dante na sua tensão com o poeta Dante da Maiano, reflexo dos primeiros passos no processo de dire parole per rime, apresenta no interior das rimas uma regra geral, isto é, constituírem-se em rimas de amor. Malato (1999, p. 86) afirma que é essa tensão entre os poetas é fundamental para Dante dar os primeiros passos na arte de compor palavras por rimas.

Sabemos que o conceito amoroso não é matéria nova na literatura italiana, talvez em terras italianas esse conceito tenha ganhado certa autonomia e inovação, sendo que tal conceito, a princípio, está ligado a um processo de amadurecimento dentro de um código atribuído a André Capelão, cujos escritos são tidos como primeiros documentos amorosos antes do florescer da literatura amorosa provençal.

No seu tratado amoroso, André Capelano deseja oferecer a seu amigo Gautier uma doutrina do amor, uma verdadeira summa amatória, de acordo com Castilho Benedetti (2000, p. xxxvii), importante por codificar, de maneira metódica, a

\footnotetext{
${ }^{45}$ Compete a ti julgar e não te esquives/ ó homem que és tão sábio, tão louvado/ Para não discutir sonhos que vive/ às palavras mais finas vou atado. Wanderley, Jorge (1996, p. 35)
} 
arte cortês de amar, ou seja, uma arte não acessível a meros mortais. A maneira como se desenvolve a argumentação presente nos diálogos e outras partes do tratado evidenciam uma busca por um processo conceitual que imprima rigor aos sentimentos, aflorados a partir dos desejos carnais.

A concepção amorosa no corpus do tratado se apoia em autoridades para justificar o conhecimento de André Capelano, no que diz respeito a autoridades intelectuais como, Zózimo, Ovídio, Avieno, Horácio, Juvenal, Quintiliano, Catão, Homero, Lucano, Estácio, Virgílio e Boécio, importantes por imprimir certa profundidade ao tratado, que é sumariamente famoso na ldade Média, e possivelmente tenha sido lido ou chegado até as mãos de Dante.

Santangelo (1921, p.15) traz à discussão a ideia de que Dante lera textos de trovadores diversos, entretanto nenhum documento comprova tal hipótese; 0 pesquisador chega a tal conclusão pautando-se em grande parte da crítica dantesca moderna que aponta para uma leitura feita pelo poeta das razos, aceitando ainda que a estrutura e trato da Vida Nova têm o seu modelo nas razos provençalis ${ }^{46}$.

O uso do conceito de razão é outra matéria frequente na poesia estilnovista, o intelecto é uma forma de linguagem capaz de ornar o novo modelo de composição, sugerindo uma relação direta com o próprio pensamento que culmina em uma elevada busca por um estilo refinado e que surge de um desejo de apreender o conceito amoroso, o amor em sua acepção sapientiae, cujo amor tem como ponto de partida e chegada a devoção à sabedoria santa.

Tal sabedoria personificada, de modo geral, na figura de Maria, apresenta a mente como espaço desse amor, cujos sentidos são afastados nesse momento, dando lugar à paixão intelectual que se une à ideia de intelecto possível com a inteligência ativa, resultando na Divina sabedoria (VILLANI, 1994, p.182).

A manifestação desse amor se configura com a visão de Maria, como modelo de pureza, esboçando, dentro dessa produção, uma mulher com características celestes, capaz de iluminar através de suas virtudes divinas, conforme Asor Rosa, o coração do poeta (ASOR ROSA, 2009, p.112). Vale lembrar que tal ideologia pode

${ }^{46}$ Santangelo (1982, p.16) Fala de um conjunto de razões (razos), textos medievais que serviam como modelo para as composições. $O$ autor afirma que, se Danto não tivesse conhecido o gênero, talvez o Vida Nova não teria a forma que conhecemos hoje. 
ser encontrada na poesia de Guido Guinizelli, que utiliza vocábulos específicos para nomear o feminino, todos ligados a uma vertente religiosa conforme exemplos? Madonna fin amor ched eo vo porto mi donna sì gran gioia ed allegranza (Rime II; 1 2); Madonna da voi tengo ed ho valore (Rime, II; 37).

Uma autoconsciência literária ronda os estilnovistas, ou seja, outro modo de colocar-se diante de uma nova exigência de criação poética anima o espírito de Dante e de seus pares. A singularidade e o subjetivismo nas composições do florentino são frutos dessa autoconsciência literária, não só a vivenciar a poesia como fato exaustivo, mas como verdadeira Weltanschauung ${ }^{47}$, resultado de uma contínua busca estilística e retórica (ANGIOLILLO, 1994, p.51).

Essa busca pelo embasamento clássico tem como pressuposto uma produção fundamentada nos grandes nomes da poesia clássica, que tiveram enorme difusão na Idade Média, conforme assinala Patrick Boyde (1979, p.79) ao citar Ars Poetica de Horácio.

A poesia do doce estilo novo, ainda que tenha a matéria amorosa como elemento fundador, é uma poesia com características epistolares, direcionadas a um grupo seleto, o dos chamados "fedeli d'amore" que mantinham certo código linguístico. A ciascuna alma presa e gentil cuore (Vida Nova I.i); Voi che per la via d'amor passate (V.N. II., i); Donne ch'avete inteletto d'amore ( Vida Nova, XIX., i) mostram que o pensamento envolvendo o conceito amoroso, a partir de Dante, restringia a possibilidade de uma compreensão geral ${ }^{48}$.

Só aqueles que se apresentassem em grau de comungar com essa nova abstração seriam capazes de compreender e, quando possível, responder aos enigmas amorosos. No lugar da corte, os círculos de amizade fundamentavam essa nova maneira de composição, o que estreitava ainda mais o círculo daqueles que poderiam participar do movimento. Uma nova aristocracia compunha o movimento, ou seja, os "espíritos" eleitos que podiam participar desse grupo estavam ligados

\footnotetext{
${ }^{47}$ Crença.

${ }^{48}$ Auerbach (1997, p.39) A poesia provençal desde o seu começo se distinguiu de qualquer arte popular por alguma coisa mais que suas características sociológicas, havia um segundo princípio de seleção baseada diretamente em formas humanas e culturais. A convicção de serem uma raça especial de homens, uma rigorosa elite social e espiritual, uma sociedade secreta dos eleitos moldou toda a maneira de ser, seu sentido de companheirismo, sua suprema elegância.
} 
não mais por um vínculo de classe apenas, mas por certo refinamento intelectual (ASOR ROSA, 2009, p. 112).

Essa atmosfera de mistério e obscuridade poéticos - e temos que entender obscuridade como um processo que não permite uma clareza imediata — produzem um efeito novo nas composições líricas. A crítica tradicional reitera, diante dessa nova roupagem, na qual os poetas revestem o amor e com isso seu objeto, a mulher, explicando-a como uma moda mística e bizarra do tempo (VALLI, 2008.p. 28).

Essa crítica tradicional e historicista sustenta ainda que Guido Cavalcanti tenha dirigido o seu poema Donna mi prega, a uma mulher real; hipótese discutível, tendo em vista que, na escola estilnovista a figura da mulher é semelhante à de Maria, ou seja, idealizada. Essa discussão carrega marcas imprimidas pela poesia trovadoresca cuja presença física da mulher evidenciava-se nas composições, todavia, não se pode esquecer, que a escola estilnovista é a modificadora dessa presença real da mulher em sua manifestação conceitual, bem como na perspectiva misteriosa que moldava a poesia da escola de Dante.

Dante, partícipe do conjunto de poetas dessa perspectiva enigmática, colocase como uma figura brilhante e busca em Cavalcanti uma influência lexical que o acompanhará por toda a sua trajetória:

Tutto l'altro che segue poi di questa canzone, sofficientemente è per l'altra esposizione manifesto. $E$ così, in fine di questo secondo trattato, dico e affermo che la donna di cu' io innamorai appresso lo primo amore fu la bellissima e onestissima figlia dello Imperadore dell'universo, alla quale Pittagora puose nome Filosofia ${ }^{49}$. (ALIGHIERI, Convivio, trat II cap. xv)

A filosofia reveste o campo poético dos "fedeli d'amore", sendo que as figuras retóricas apontam para uma relação possível entre filosofia e poesia, um processo combinatório que em Dante encontra profunda referência.

49 Tudo o que segue depois dessa canção suficientemente é para outra exposição manifestar. E assim no fim desse segundo tratado, digo e afirmo que a mulher de quem eu me apaixonei pouco depois do meu primeiro amor, foi a belíssima e honestíssima filha do Imperador do universo, à qual Pitágoras nomeou filosofia. 
É verdade que o poeta já possuía notável compreensão de que o homem nasce para o saber e de que não havia um limite para tanto. Dante sugere o casamento da poesia com a filosofia, pois para ele a poesia não é mais o gênero responsável por divertir a corte, mas um saber, que unido a elementos da filosofia conduz o homem ao conhecimento de si, bem expresso por Ulisses na Divina Comédia ao dizer: o conhecimento é uma necessidade e pela história humana fomos moldados para tal, considerate la vostra semenza, fatti non foste a viver come bruti, ma per seguir virtute e canoscenza (Inferno: Canto XXVI, 116-120). Reconhecer tal fato é ter a certeza de que também no campo poético o convite é bem vindo, ou seja, poesia e filosofia sobem ao altar numa união modificadora do fazer poético.

A terminologia dantesca em, principalmente, Donne ch'avete intelletto d'amore... (Vida Nova., xix); Venite a intender li sospiri miei... (Vida Nova, xxxii); Era venuta ne la mente mia... (Vida Nova, xxxiv) versa sobre um raciocínio que exige certa abstração e preparação por parte desses poetas ${ }^{50}$ : a produção de rimas, tendo como base a matéria amorosa, deve ser compreendida segundo a terminologia escolástica e segundo uma distinção de matéria e de forma ( Perez apud VALLI, 2009, pp.38-39). As rimas que estão revestidas da matéria amorosa podem estar envolvidas por outra significação que não aquela ligada especificamente ao amor como conhecemos.

Isso seria fruto de uma mente inquieta e sábia, sendo que Spina (1921, p. 39) afirma que "a verdadeira substância da poesia deve o douto buscá-la nos modelos ideais da vida e dos costumes dos homens; para isso era necessário que os jovens se preparassem desde cedo na escola da sabedoria...", Dante une uma série de conhecimentos em um período de profunda busca e maturidade dentro da ars poética, fazendo da produção algo ligado à própria existência, assim a poesia transforma-se em objeto que garante o desvelamento da própria vida, conforme Angiolillo:

Ritengo che la particolarità di Dante di vivere secondo la poesia e di poetare secondo la vita, sia stato l'andidoto più eficace non solo contro le estremizzante concettualizazione e cerebralizazzioni di quella poesia, ma anche contro le seduzioni e le lusinghe culturali in

\footnotetext{
${ }^{50}$ Referência aos poetas do Estilo Novo.
} 
genere. Perchè se la poesia giungeva a investire la vita dei suoi valori di sensibilità, di canoscenza, di poeticità, però, interveniva a tenere nell' alveo di una fenomenologia storico- misterico- esistenziale una poesia che, tendeva ad evaderne ${ }^{51}$. (ANGIOLILLO, 1994, p. 35).

O percurso de aprendizagem poético de Dante é resultado de seu contato com diversas literaturas e expressões até alcançar o notável valor que ele já possuía na Florença do século XIV. Sua existência foi marcada pela busca constante por diversas manifestações intelectuais e pela vivência direta dos acontecimentos políticos da sua Florença. A sua obra, desse modo, é uma tentativa de síntese poética sistemática de toda uma realidade universal (Auerbach, apud MALATO, 2009, p.374), sendo que sua noção e visão de poesia buscam bases em toda arte poética latina, e Virgílio, dentro desse referencial latino, é aquele poeta com quem Dante estabelece uma relação de intensa amizade, como notamos nos seguintes versos do Inferno:

$$
\begin{aligned}
& \text { Or se' tu quel Virgilio e quella fonte che } \\
& \text { spandi di parlar sì largo fiume?"... "O de li altri } \\
& \text { poeti onore e lume, vagliami ' I lungo studio e } \\
& \text { 'I grande amore che m'ha fatto cercar lo tuo } \\
& \text { volume }^{52} \text { (Inferno I: } 80-84 \text { ). }
\end{aligned}
$$

O crescimento intelectual de Dante e sua imensa vontade de dar formas à imortal Beatriz, através da poesia, o coloca como grande poeta, experimentador de um novo conceito. Vale lembrar que a condição humana da mulher dentro da escola estilnovista é fundada na ideia de metamorfose, processo novo ainda não executado dentro do conjunto poético lírico amoroso medieval. Um processo mental explicado através da palavra, que em Dante se cristaliza em uma imagem quase sublime resultando no mais absoluto conceito feminino. A palavra assume um poder

\footnotetext{
${ }^{51}$ No meu ponto de vista a particularidade de Dante em viver segundo a poesia e de poetar segundo a vida, foi o antídoto mais eficaz não só contra os extremizantes conceitualizações, celebrações e racionalização dessa poesia, foi também contra as seduções e as ilusões culturais em geral. Porque se a poesia alcançasse os valores de sensibilidade, de conhecimento, de poeticidade, porém interviria no alvéolo de uma fenomenologia histórico existencial, de modo geral, uma poesia que tenderia a evadir-se dela. (Tradução nossa).

${ }^{52}$ Serás tu, pois Vírgilio, aquela fonte/ de que tão grande rio em fala espume?/ Ihe respondi baixando humilde a fronte/ Ó dos outros poetas honra e lume/ valham-me o grande estudo e o grande amor/ que me fez penetrar no teu volume (Tradução de Vasco Graça Moura).
} 
referenciador que ultrapassa a ideia, chegando a realizar o dito; o poeta aponta uma evidente transformação da figura feminina dentro da sua obra. A este propósito Bologna (1998, p. 25) discorre sobre o conceito de palavras-coisas como estratégia dantesca do reconhecimento como vida nova das palavras que se tornam imagens.

O ponto culminante de mudança poética em Dante passa pela morte de sua musa inspiradora, narrado nos poemas de A Vida Nova, que provoca uma profunda reflexão em torno do processo de existência, levando-o a pensar em novos valores e interesses; os poemas que compõem a Vida Nova para Malato (1997, p.105) têm um caráter confessional, pois é importante registro de toda a poesia de Alighieri após a morte de Beatriz.

No que se refere ao conjunto de poemas que compõem a obra lírica dantesca, pode-se dizer que foram escritos de forma esparsa, sem uma ideia de cancioneiro, sendo que o poeta, segundo Sanguinetti (1999, p.ix), em momento algum pensou em reunir os seus poemas em um corpus unitário, cabendo à crítica moderna a organização e compilação de todas as produções a partir das datações que correspondem aos escritos de composição antes e após sua juventude ${ }^{53}$.

O soneto que a crítica aponta como primeira produção de Dante, A ciascun' alma presa e gentil core... (Vida Nova, III; Rime, i), imerge a figura do trovador em uma atmosfera ainda desconhecida, na qual sua lírica amorosa não será a mesma após os primeiros versos dessa poesia, já estilnovista, em um universo onde o amor ganha status humano, tornando-se insígnia dessa poética. Como bem aponta os versos... salute in lor sengor, cioé amore...(Vida Nova, III; Rime iii), o poeta reitera seu estilo ornando-o de uma nova veste significativa endereçada a mentes capazes de aceitá-la conforme suas próprias palavras, Voi che savete ragionar d'amore (Rime, XXIX; i).

O amor é um saber, um conceito apreensível pela clareza e preparação intelectiva, possibilidade não encontrada na lírica trovadoresca amorosa anterior, por exemplo, aquela provençal, conforme já explicado.

\footnotetext{
${ }^{53}$ Malato (1999, p.106): o novo endereço da produção lírica de Dante reduzida no que diz respeito a sua fase juvenil, isso tudo segundo uma ordenação de Bardi, gira em torno de conjunto de sessenta rimas abandonadas do primeiro decênio, antes da escrita da Vida Nova.
} 
$\mathrm{Na}$ escola estilnovista, a adesão dessa nova maneira de produção por parte dos poetas passa por um processo enigmático, discutido por Rougemont (2006, p.139), que aponta que o estilo também enigmático dos trovadores, no que concerne ao amor, está ligado a uma tese catara; a grande maioria dos autores está de acordo com tal pressuposto, devendo-se a esse o catarismo ${ }^{54}$ a ocultação do segredo do poeta cortês, mesmo àqueles convertidos à ortodoxia católica.

O ponto inicial da amizade entre Dante e Guido $^{55}$ foi marcado por uma correspondência poética frequente e duradoura entre os vates da poesia estilnovista. Segundo Sanguinetti $\left(2001\right.$, p.6) questo sonetto ${ }^{56}$ fue risposto da molti e di diverse sentenzie; tra li quali fue risponditore quelli cui io chiamo primo de li miei amici. Após a composição desse poema, Dante sinaliza um conjunto de respostas através de sentenças que pudessem explicar artificiosamente a matéria amorosa: ele procurava um novo encantamento e uma nova linguagem.

A poesia estilnovista deveria artificiosamente compor-se de modo a revelar 0 seu segredo, a partir da mudança de uma ou duas palavras, possivelmente as palavras de duplo sentido, colocadas de modo que também o sentido literal pudesse e tivesse a sua significação, a sua lógica e, possivelmente, o seu pathos, conforme afirma Valli (1994, p.180).

\footnotetext{
54 Denis Rougemont (2006, p. 123) A origem do Catarismo, heresia, remonta às seitas neomânicas da Ásia Menor e das Igrejas Bogomile di Dalmazia e Bulgária. Os Cataros puros estavam ligados às grandes correntes Gnósticas que atraversaram o primeiro milênio do cristianismo. É notável que a Gnosis, assim como as doutrinas de Manes, afundam nas raízes da religião dualista do Irã. Repetiuse já por vários anos que nunca se soube o fundamento da seita, e por essa razão a inquisição queimou todos os livros do culto e os tratados doutrinais da Heresia e as únicas que restaram foram retiradas de interrogatórios dos acusados. Na realidade a descoberta e a publicação no ano de 1939 de uma obra teológica $O$ livro dos dois príncipes junto a aparição de um Novo Testamento e de rituais usados pelos heréticos, permite hoje conhecer na sua complexidade e em algumas variações dos dogmas da lgreja d'amore. (Tradução nossa).

${ }^{55}$ Malato (1999, p.19) no seu estudo intitulado Dante e Guido Cavalcanti: il dissidio per la Vita nuova e il Disdegno di Guido, aponta que pra lá das poucas alusões iniciadas por Contini, nada na Vida Nova deixa supor conhecimento por parte de Dante das canções de Guido; enquanto, ao contrário, ganha a diversidade das respectivas posições teóricas, o fato mesmo que Dante pudesse conceber a dedicação a Guido no seu livreto, com as atestações de amizade e de estima, as quais evidentemente exprimem uma profunda solidariedade intelectual com aquele sutil envolvimento do outro. (Tradução nossa).

${ }^{56}$ Este soneto [a ciascuna alma presa e gentil cuore... a cada alma presa e de gentil coração...] foi respondido por muitos e diversos modos, entre os quais o replicou um dos meus primeiros amigos. Sanguinetti (2001, p. 06): esse amigo é Guido Cavalcanti, a figura mais prestigiosa e dramática da escola estilnovista. Exerceu sobre Dante uma notável influência nos anos da sua juventude. (Tradução nossa)
} 
O amor é desvelado como um conceito com traços humanos cheio de psicologia. Guido no soneto "Vedeste, al mio parere, onne valore..." sentira na poesia do amigo Dante os efeitos que o amor provoca, sendo que para Biondolillo (1964, p. 28), Cavalcanti sentiu os efeitos naturais do amor, descobrindo a psicologia desse humano sentimento nos diversos aspectos que ele se apresentara.

A característica do amor personificado com traços humanos aponta para uma poética que quer conhecer o conceito além do que ele permite. $O$ amor é uma visão que se torna matéria viva na poesia. André Capelano já discorria sobre o amor como característica visionária, ressaltando que Amor é uma visão... (Tratado do amor cortês, cap I). O amor da escola de Dante por sua vez, manifestava-se ainda que improvisamente e violentamente a partir de uma visão, mas a visão da Madonna (VALLI, 1997, p.183).

Dessa forma, pensar a poesia do doce estilo novo é fazer um itinerário capaz de apresentar os seus maiores representantes, delineando as características desse movimento, importantes na compreensão do espaço da mulher e de suas manifestações que, por ventura, apareçam no corpus dessa poesia; por isso Guido Cavalcanti e Dante se justificam como primeiros representantes. 


\subsection{DANTE E O CONCEITO DE MULHER NA SUA LÍRICA JUVENIL}

O soneto A ciascun' alma presa e gentil core (Vida Nova. III, 1) é um dos primeiros poemas compostos por Dante na sua juventude, sendo escrito provavelmente no ano de 1283. Como afirma Gorni, a primeira composição esta de acordo com uma lógica interna dentro do próprio corpus da produção lírica do poeta (2009, p. 128). A obra de Dante desde os poemas da Vida Nova assim como aqueles que compõem o corpus "delle rime" têm um caráter confessional, e como ressalta Malato, os poemas que fazem parte da Vida Nova foram retirados do corpus das Rimas para formar uma obra autônoma, na verdade concebida e realizada como uma "razão" já apontada anteriormente (MALATO, 1997, p. 23).

O modelo de classificação e sistematização é fruto de Barbi (1956), que a partir de um trabalho complexo e delicado, conduzido a partir de uma centena de códigos e publicações antigas, teve o mérito de ordenar a obra do poeta, propondo uma plausível solução aos problemas fundamentais de atribuição, bem como os organizando cronológica e tematicamente o conjunto de Rimas de Dante.

No que diz respeito ao modelo de composição presente na canção $A$ ciascuna alma presa e gentil core (Vida Nova), o poeta segue, de modo pontual, a linguagem de Guinizelli. A novidade guinzelliana, discute Begeleider (2008, p.30), está no uso que o poeta faz dos topoi e das metáforas, tradicionais, sendo que sua novidade talvez se insira em um novo contexto filosófico e teológico, que coloca em destaque a nova linguagem, ambas usadas na poesia - em particular notabilidade na Vida Nova - destacando, ainda, o elevado papel da palavra dentro do quadro de composição.

O amor descrito no soneto $A$ ciascun 'alma presa (Vida Nova) ganha uma notoriedade formal com sua leveza, e uma harmonia entre os elementos que formam o conjunto poético, marcado de maneira pontual por Dante, que anuncia, dentre outras novidades, uma poesia com grande fluidez narrativa (ASOR ROSA, 2009, p. 131). 
A leitura de personificação do conceito amoroso exige uma noção de fidelidade e um profundo senso de abstração por parte dos escritores dessa escola. Assim, tais poetas eram pessoas que se interessavam pelo amor do outro, pela sinceridade e fidelidade ao amor; uma seita que teve como fundamento o vínculo unívoco com esse conceito.

Essa ideia de seita está fundada, além da linguagem secreta, em um frequente uso vocabular da obra Fedeli d'amore. Gorni (2008, p.163), em um estudo da lírica dantesca, coloca em evidência um contínuo uso, em versos na Vida Nova, do sintagma fedeli d'amore (Vida Nova; III 9; VII 7; VIII 7,5,9; XII 2; XIV 14, 21; XXXII 4) levando a uma especulação sobre a associação de Dante a uma seita secreta que teria como nome "fedeli d'amore".

Ainda sobre $A$ ciascun alma presa, uma leitura a partir do olhar da crítica realística, que se apoia naquilo que Dante afirma ipisis literis, apresenta como elemento de interpretação um sonho premonitório da morte de Beatriz, tido pelo poeta em 1823. No entanto, a poesia de Dante não permite uma leitura única, o que fundamenta o universo dantesco è sua grandeza de pensamento, pois ele é um poeta do mundo, que assume representar a humanidade através de sua poesia, sendo assim, como ressalta Contini, não basta uma leitura superficial ou literal de sua obra (CONTINI, 1995, p. 10).

$\mathrm{Na}$ construção desse soneto o poeta busca um novo olhar direcionado ao conceito amoroso, procura consciente e racional que provocou uma profunda busca por um lirismo que colocasse em primeiro plano a contemplação. Ao seguir as prescrições da seita amorosa fedeli $d^{\prime}$ amore o poeta aconselhara de maneira prudente a criar no universo imaginário das pessoas a certeza de que ele estava apaixonado por uma mulher real.

O universo enigmático do qual emerge a poesia estilnovista traz consigo um grande problema acerca da verdadeira existência dessa mulher delineada por ele, ou seja, Beatriz. Contudo não é nossa intenção discutir ou resolver essa questão. A esse propósito afirma Gessani:

Ci si può chiedere se sia veramente Beatrice questa Donna, al tempo del sonetto, o se Dante non riferisca a Beatrice, nella Vita Nuova, versi scritti per un'altra donna. La questione è chiaramente di quelle 
irresolubili, ma ritengo, proprio per l'interpretazione che qui tento di questi versi, che ben difficilmente l'aura sacrale che circonda l'azione descritta da Dante si sarebbe data nei confronti di una donna diversa di Beatrice. ${ }^{57}$ (GESSANI, 2004, p.49)

Por sua vez, a morte de Beatriz é descrita pelo poeta na sequência em prosa que explica o poema,

"lo era nel proponimento ancora di questa canzone, e compiuta n'avea questa soprascritta stanza, quando lo segnore de la giustizia chiamoe questa gentilissima a gloriare sotto la insegna di quella regina benedetta virgo Maria, lo cui nome fue in grandissima reverenzia ne le parole di questa Beatrice beata ${ }^{58 ،}$ (V.N.,xxviii).

O nome de Beatriz pode, nesse caso, estar ligado à ideia de beatitude ${ }^{59}$ e ser apenas mais um conceito que nos sugere uma mulher real, o que, por sua vez, levanos ao pensamento de Bologna,

Nella scrittura dantesca le distanze di anni, nella vita, e di parole, idee e immagini, nelle opere, sono annullate daí fulminei richiami di vocaboli-cifre, che costituiscano nel contempo i ritorni dei temi e dei personaggi che li rappresentano, e la loro ri-tematizzazione ${ }^{60}$. (BOLOGNA, 1998, p.15)

A aparição da personagem Beatriz indica o início da relação de Dante com o feminino que perdurará até sua obra tida como maior, a DC. O poeta apresenta, de

${ }^{57}$ Perguntamos-nos se Beatriz foi realmente essa mulher no tempo de composição do soneto, ou se o poeta não faz referência à Beatriz na Vida Nova, ou se são versos para outra mulher. A questão é claramente daquelas insolúveis, mas creio, por vias da interpretação destes versos, que é altamente improvável que a aura sagrada que envolve a ação descrita por Dante compondo uma mulher diferente de Beatriz. (Tradução nossa).

${ }^{58}$ Eu estava ainda propondo essa canção, e completado essa sobrescrita instância, quando o senhor da justiça chamou esta gentilíssima à glória, sobre o sinal da rainha bendita virgem Maria, cujo nome foi em grande reverência nas palavras de Beatriz beata. (Tradução nossa).

${ }^{59}$ Chiavacci $(2009$, p. 14) No rimário que compõe A Divina Comédia comentada por Ana Maria Chiavacci Leonardi, ela aponta que Dante, vive um ecumenismo cristão e usa os termos da teologia próprios da tradição, a ideia de beatitude em Dante está fundada no conceito teológico bíblico, as beatitudes são promessas que Jesus faz no evangélio acerca do reino de Deus e da sua alegria para aqueles que atenderem o seu chamado esperando a sua vinda, testemunhando-a com a pobreza de espírito, mansidão, o pranto, o desejo da justiça, a misericórdia, a pureza de coração, o espírito de paz e os que são perseguidos por causa do reino de Deus. (Tradução nossa).

${ }^{60} \mathrm{Na}$ escrita de Dante as distâncias dos anos, na vida, e de, palavras, idéias e imagens na obra, são anuladas quando se tem como força os vocábulos-cifras que constituem retorno aos temas e personagens que os representam, assim como a retomada destes temas. (Tradução nossa). 
acordo com a linguagem estilnovista, a figura feminina de maior vulto, a sua Beatriz, sendo o amor o seu grande inspirador conforme os seguintes versos do Inferno, quando amor mi spira, noto, e a quel modo ch'e' ditta vo significando ${ }^{61}$ (Inferno: XXIV, 52-54). Dante, diz Chiavacci (2009, p.710), define com essas palavras a verdadeira novidade das suas rimas que certamente são seguidas por seus companheiros de poesia. Nesse contexto, o amor é representado como aquele que dita os parâmetros dessa nova escola poética.

Vale lembrar que esse amor ganha contornos diferenciados, quando comparado ao conceito amoroso presente na poesia trovadoresca-provençal. Para André Capelano o "Amor vem do verbo amar, que significa "prender" ou "ser preso". Pois quem ama fica preso nas malhas do desejo e o desejo prende o outro em seu anzol' (CAPELÃO, 2000, p.11).

Essa aparição de Beatriz como musa e elemento maior é marca da sua poesia e aponta para o novo. Importante ressaltar que a maneira de poetar pensada pela escola estilnovista já é apontada em um soneto de Bonagiunta Orbicciani da Lucca $^{62}$ a Guido Guinizelli,

\author{
Voi che avete mutata la maniera \\ de li plagenti ditti dell'amore \\ de la forma dell'esser la dov'era \\ per avanzare ogn' altro trovatore \\ avete fatto como la lumera \\ ch'e le scure partite dá splendore \\ ma no quine ove luce l' alta spera
}

\footnotetext{
61 Quando o amor me traz inspiração, percebo a partir do modo que ele dita, orno minha poesia. (Tradução nossa).

62 Bonagiunta viveu entre a primeira e a segunda metade do século, pelo menos até 1296 . Foi o primeiro a introduzir na Toscana a poesia amorosa, nascida na corte siciliana, sendo o mais possivelmente fiel ao modelo. Quem veio depois dele foi Giuttone d'Arezzo, estes dois são os principais autores que precedem ao nascimento do Estilo Novo. Chiavacci (2009, p. 704).
} 
la quale avansa e passa di chiorore.

Cosi passate voi di sottiglianza

e non si puo trovar chi bem ispogna

cotant' è iscura la vostra parlatura.

Ed è tenuta gran dissimiglianza

ancor che' I senno venga da Bologna

traier canson a forza di scrittura ${ }^{63}$

Essa visão diferente, apontada por Bonagiunta Orbicciani da Lucca, encontra em Dante o seu auge, sendo que a sua poesia está marcada pelos ornamentos da religião cristã, seja no universo conceitual ou no linguístico que, por sua vez, acompanharão a figura da mulher dentro da lírica estilnovista. Auerbach (apud GESSANI, 2004, pp.26-27) afirma que:

Proprio I' ispirazione religiosa nel trattare della donna costituisce un tratto distintivo del Dolce Stil Novo rispetto ai poeti provenzali. Ma forse questo giudizio è influenziato più dalla poesia dantesca che da quella degli altri poeti stilnovisti, perche sarebbe ben difficile trovare un qualcosa di religioso, per esempio, nella poesia di Cavalcanti e di Lapo Gianni; e sempre dovremmo considerare che la religiosità sembra resiedere, in questi altri poeti e nello stesso Guinizzelli, più in un certo linguaggio adottato nel trattare della donna amata che in un attegiamento di sublimazione e sacralizzazione dell'amore. ${ }^{64}$

Enredada em uma teia que denota sua condição sugestiva, a mulher apresentará um status enigmático, sendo tal condição importante por suscitar uma

${ }^{63}$ Vos que mudais a maneira/ dos já existentes ditos amorosos/ da forma em essência que se tinha/ para avançar cada trovador/ fazeis iluminando com a vela/ que no escuro esplende/ Não esquive que luz alta espera/ a qual avança e clareia// Assim passais vós de sutileza/ e não se pode encontrar quem bem exponha/ quanto é escura a vossa palavra/ E é evidente grande diferença/ ainda que o sinal venha de Bolonha/ trazer canção com a força da escritura. (Tradução nossa).

${ }^{64}$ Certamente a inspiração religiosa no tratar a mulher constitui uma diferença no doce estilo novo em relação aos poetas provençais. Mais talvez este juízo seja influenciado mais pela poesia dantesca que daquela dos outros poetas estilnovistas, porque seria bem difícil encontrar alguma coisa religiosa, por exemplo, na poesia de Cavalcanti e de Lapo Gianni. E sempre devemos considerar que a religiosidade parece residir nestes outros poetas e no estilo de Guinizzelli, mais em uma certa linguagem adotada no tratar a mulher amada e que numa afinidade de sublimação e sacralização do amor. (Tradução nossa). 
incerteza acerca do espaço feminino dentro dessa lírica, e aqui devemos entender esse espaço como uma figuração. Essa ideia de poesia secreta encontra uma possível justificativa no ambiente da seita, que para Valli (2008, p184) trata-se de um espaço contemplativo. Nesse contexto, a maneira diferente de poetar do circulo estilnovista, que apresenta mudança de matéria e linguagem quando se trata da mulher, faz Bonagiunta, ao analisar o sexto círculo do Purgatório, reconhecer em Dante um novo vate desse estilo, o criador dessa nova imagem de mulher,

\section{Ma dì s'i' veggio qui colui che fore}

trasse le nove rime, cominciando

"Donne ch' avete intelleto d'amore"65 (Purgatorio: XXIV., 50-52)

A canção, "Donne ch'avete inteletto d'amore", que Bonagiunta reconhece como produzida por Dante, inaugura um conceito de louvor à mulher, seja ela real ou apenas fruto da imaginação. Esse poema dantesco revela uma escrita que será marcada pela presença dessa mulher, que será, por sua vez, eternizada pelas diversas leituras, em diferentes épocas. Ao nomear Beatriz, como sua Madonna que é disiata in sommo cielo (Vida Nova, XXIX), o poeta encontra certa conformidade conceitual cujo objetivo é definir uma história amorosa ideal, sendo o próprio poeta que nos leva a construir essa ideia que a sua Beatriz seja, sobretudo, uma eficácia onomástica (GORNI, 2009, p.113).

Com isso Dante, torna-se o poeta da consciência e do imaginário coletivo, e, ainda, ousa utilizar as espirais da mitopoética (ANGIOLILLO, 1994, pp. 18-19), criando símbolos dentro de uma cultura, que nos motiva a pensar por imagens. Tal ousadia destaca o poeta como um homem inquieto que vê no processo intelectivo amoroso uma virtude a ser seguida, e a exemplo de Horácio em sua poética, busca constantemente inovar sua ideologia artística. A este propósito vejamos a posição de Trigalli:

\footnotetext{
${ }^{65}$ Mas diz se vejo aqui quem soube pôr/ cá fora as novas rimas começando/ Senhoras que entendeis tanto de amor. (Tradução de Vasco Graça Moura)
} 
Os nossos poetas nada deixaram sem experimentar e não muito pequeno louvor mereceram os que ousaram abandonar as pegadas dos gregos e celebrar os feitos nacionais ou os que fizeram representar as peças pretextas ou togadas. Nem o Lácio seria mais potente pelo valor e pelas armas gloriosas do que por sua língua, se o trabalho lento da lima não aborrecesse a todos os nossos poetas. (TRIGALLI, 1924, p.20)

Vale lembrar que, quando se discorre sobre ousadia e mudança, a ideia assumida por Dante e seus condiscípulos, dentro do processo de composição do estilo novo, não excluía os elementos das experiências poéticas anteriores, pelo contrário, as antigas vivências contribuíram para o enriquecimento das novas tentativas, como bem pontua o crítico Asor Rosa:

lo stil novo non deve essere considerato in nessun modo il prodotto di uma mera inovazione intellettualistica; il travaglio di idee e di sentimenti che esso rivela, porta il segno di un'esperienza giovanile estremamente fervida e appassionata, in cui lo spirito di gruppol'amicizia-gioca un ruolo fondamentale. Dientro le teorie e le scelte retorico-stilistiche si cominciano intravedere, in maniera molto più marcata che in passato, i tratti delle singole personalità ed esperienze individuali. È impossibile, è sbagliato enunciare uma teoria generale dello stil nuovo: tale teoria non è che la somma delle tante esperienze individuali , che hanno contribuito- entro i limiti detti- a determinarla ${ }^{66}$. (ASOR ROSA, 2009, p. 111)

Seguindo uma sequência ordenada por Barbi ${ }^{67}$ (1956), no que diz respeito às composições do conjunto de rimas de Dante, partimos do soneto Guido i vorrei che tu Lapo ed io, presente no corpus das Rimas como ponto inicial para pensar numa apresentação de imagens femininas, conforme segue abaixo:

${ }^{66} \mathrm{O}$ estilo novo não deve ser considerado em nenhum momento como mero produto inovação intelectual; o confronto de ideias e de sentimentos revelados nesta escola - a estilonovista - carrega consigo o sinal de uma experiência jovem, extremamente tórrida e apaixonada, em que o espirito do grupo de amizade exerce papel fundamental. Atrás das teorias e das escolhas retóricas e estilísticas surgem, de maneira muito mais marcada que no passado, os traços das personalidades e experiências individuais. É impossível e um equívoco enunciar uma teoria geral do estilo novo, tal teoria não é mais que a soma das experiências individuais que contribuíram - limitadamente, para sua determinação. (Tradução nossa).

67 Vide Gorni, 2009, p. 128. 


\begin{abstract}
Guido i' vorrei che tu e Lapo ed io fossimo presi per incantamento e messi in un vasel, ch'ad ogni vento per mare andasse al voler vostro e mio;
\end{abstract}

sì che fortuna od altro tempo rio non ci potesse dare impedimento, anzi, vivendo sempre in un talento, di stare insieme crescesse 'I disio.

E monna Vanna e monna Lagia poi con quella ch'è sul numer de le trenta con noi ponesse il buono incantatore:

e quivi ragionar sempre d'amore, e ciascuna di lor fosse contenta, sì come i' credo che saremmo noi

Importante ressaltar que esse soneto, Guido, i' vorre ${ }^{68}$, de acordo com Gessani (2004, p. 23) é um dos mais antigos escritos de Dante, e é importante não por demarcar o período de tensão com Guido, mas por indicar a aparição de nomes ligados a mulheres, em especial nos poemas E monna Vanna e monna Lagia poi, com quella ch'è sul numer de le trenta (Rime; IX., 9-10). Tais indicações, em uma primeira leitura, evidenciam se tratar de nomes atribuídos a mulheres reais que apresentam certo vínculo com cada poeta por uma ordem de natureza real ou ideal. Segundo Malato:

Dove la magica navicella, "il vasel, ch' ad ogni vento/ per mare andasse" in cui Dante immaginna di andare serenamente con gli amici, Cavalcanti e Lapo Gianni, e le rispettive donne - "monna

${ }^{68}$ Giuseppe Ledda (2008, p. 18) diz que o soneto ilustra nas formas do souhait provençal o que ele esclarece como composição na qual se manifesta desejos dificilmente realizáveis, aparece nessa composição de Dante certa tonalidade sonhadora dos romances corteses e das aventuras do circulo arturiano. (Tradução nossa). 
Vanna e monna Lagia", con una terza sibillinamente designata come "quella ch' è sul numer de le trenta ${ }^{69 " .}$.(MALATO,1999, p. 95)

Aqui há um problema de ordem analítica, pois se de um lado temos a crítica que discorda dessa existência feminina real, inclusive a de Beatriz, por outro lado, há os que apontam para uma mulher real na poesia da escola estilnovista. Há, ainda, uma vertente que sustenta que Dante além de celebrar uma poesia para outras mulheres diferentes de Beatriz, é o primeiro, dentro do quadro da literatura italiana, a nomear figuras femininas que antes eram ligadas a uma natureza conceitual na figura do vocábulo "Rosa". A este propósito, Valli afirma:

Nulla! Per decenni e decenni nella poesia italiana la donna non há altro nome que "Rosa", proprio (o che bel caso!) il nome del mistico fiore della persia e del misterioso fiore che si ritroverà mèta dello stranissimo amore del Roman de la Rose e del Fiore! Anzi talora si chiama addiritura "Rosa di Sorìa" o " Rosa d'Oriente" ${ }^{70 !}$. (VALLI, 1994, p.56)

As mulheres citadas, "monna Vanna e monna Lagia e uma terceira" no soneto fazem parte de um momento da escrita de Dante em que se estabelece certa troca ${ }^{71}$ de poemas entre seus pares com o intuito de se refletir acerca do novo estilo que culmina no ponto central dessa poesia, que encontra no amor, seu núcleo pétreo.

O poeta, a partir de sinais que descrevem uma atmosfera amorosa, apresenta um profundo desejo de estar longe, característica de cada poeta que ao lado de sua musa caminha em direção ao mar, possível símbolo de liberdade, conforme vemos no seguinte verso, per mare andasse al voler vostro e mio (Rime IX., 4). Entretanto a presença nesse espaço idealizado pelo poeta só é possível se pudessem ragionar sempre d'amore... (Rime IX, 12).

69 Onde a mágica nave "O barco que a cada vento para o mar fosse", cujo Dante imagina ir serenamente com os amigos Cavalcanti e Lapo Gianni e suas respectivas mulheres: Mona Vanna e Mona Lagia, além de uma terceira designada como "aquela que está na colocação de número trinta". (Tradução nossa)

70 Nada! Por decênios e decênios na poesia italiana a mulher não tem outro nome que não seja "rosa" certamente o nome místico flor da Pérsia e do misterioso vocábulo flor que se encontrará na metade do estranhíssimo amor de Roman da Rosa e Del fiore! Antes se chamava "Rosa di Soria" ou "Rosa do Oriente".

${ }_{71}$ Gorni (2009, p. 168) As rimas que compõe a organização que De Robertis enquadra esse soneto como rima de correspondência, a ordem pensada por ele segue os critérios de Barbi. 
A imersão da poesia em um conjunto simbólico não é muito clara no que diz respeito a suas intenções reais. Na análise desse soneto, Gessani (2004, p. 23) aponta para a necessidade de uma leitura que não fique totalmente presa ao que o soneto realmente pretende significar, ressaltando que, além de estabelecer um momento de composição juvenil de Dante, já permite vislumbra sua potencialidade. O crítico ressalta ainda a adesão do poeta, nessas rimas, a uma atmosfera de amizade "gentil", característica própria do estilo novo, que é confirmada também por Contini (1995, p. 35).

Outro aspecto, que merece especial atenção, sendo de natureza temporal, liga-se ao fato de que a poesia medieval, ou o conjunto de produção artística desse período, liga-se a uma necessidade simbólica que lhe atribue aparente sentido, confome ressalta Rougemont:

Chi provi a transportarsi nell'atmosfera del medio evo, si accorge che l'assenza di significato simbolico in una poesia sarebbe un fatto ben più scandaloso che non sia, per esempio, agli occhi nostri, il simbolismo della Dama. Nella otica dell'uomo medioevale , ogni cosa ne significa un'altra, come nei sogni, e senza che in ciò intervenga sforzo veruno di traduzione concettuale. In altri termini il medioevo non ha bisogno di formularsi i significati dei simboli che adopera, né di prenderne distitamente coscienza. ${ }^{72}$ (ROUGEMONT, 2006, p.139)

Esse simbolismo, presente na obra de Dante, ganha uma profunda apreciação, por isso a manifestação de uma mulher dentro da sua poesia, em particular "nelle rime", exige um cuidado particular por parte do leitor, principalmente quando sua poesia se funda no mistério simbólico e o seu tempo corrobora com essa escolha. É pertinente analisá-la tendo em vista o que Valli (1994, p. 29) expõe, ou seja, a necessidade de colocar em evidência certa conexão de pensamentos simbólicos e iniciáticos para uma leitura das Rimas de Dante e dos poetas estilnovistas.

${ }^{72}$ Quem tenta transportar-se à atmosfera do periodo medieval, se dá conta que a ausência de significado simbólico em um poema seria um fato bem mais escandaloso do que não seja por exemplo aos nossos olhos o simbolismo da dama. Na visão do homem medieval, cada coisa significa outra, como nos sonhos, e sem que isso intervenha esforço nenhum de tradução conceitual. Em outros termos o período medieval, nisso não precisa formular significados. (Tradução nossa). 


\subsection{PRESENÇAS E IMAGENS FEMININAS NA LÍRICA DE DANTE: BASES PARA O NOVO ESTILO}

Faz-se necessário um recorte, para que se possa esboçar o que compreendemos pela representação do feminino dentro do mundo poético da lírica de Dante, sobretudo porque, muitas vezes, suas composições apresentam uma organização que não leva em conta uma ideia de cancioneiro, e os poemas que compõe o seu quadro lírico estão organizados de forma a suscitar dúvidas. O que sabemos, e isso nos aponta Gorni (2008, p. 163), entre o conjunto do quadro das rimas, é que os sonetos de matéria amorosa prevalecem. O estudo leva em consideração uma contagem vocabular, dado que nos ajuda a demarcar, dentro da organização pensada por Barbi e assumida pelos demais estudiosos, inclusive por Gorni, alguns poemas em que a "linguagem" está voltada diretamente a uma ideia de presença feminina, e que pode indicar um possível caminho a ser seguido.

É necessário esclarecer que nem sempre o uso de um vocabulário ligado ao feminino, nos poemas de Dante, justifica uma noção referencial ligada diretamente a esse universo, porém certo confronto com as palavras do próprio poeta acerca do seu profundo conhecimento sobre polissemia, é fundamental para indicar-nos um caminho. Para tanto, basta analisarmos a sua carta endereçada ao amigo Cangrande della Scala (epistola; XIII) para compreendermos que o autor conhecia muito bem a arte poética e soube como nenhum outro utilizar-se dessa arte, imprimindo-Ihe técnicas particulares e inovações na construção de sua nova poesia.

Os poemas, que fazem parte de nosso recorte, pretendem evidenciar a aparição de uma imagem ligada à mulher, sendo que foram retirados do conjunto de poemas que estão separados como rimas de correspondência. Todavia, quando necessário no cotejo entre os textos, citaremos alguns poemas do conjunto que compõe a Vida Nova, pois a figura de Beatriz é o ponto de referência ao se pensar o feminino em Dante. De acordo com Molli, ela é a mente do poeta, que se torna mulher para que todos possam contemplá-la (MOLLI, 2010, p.10).

Partimos da sequência, ordenada na edição pensada por De Robertis e descrita por Gorni (2008, p.163) tendo em vista o isolamento das rimas com indicações voltadas especificamente a um vocabulário amoroso. Deve-se levar em 
consideração, no entanto, que essas poesias de cunho amoroso não excluem uma referência à mulher, cujo conceito do feminino é evidenciado.

Todavia, pensar o universo feminino sem Beatriz, dentro da poética dantesca, representa um grande vazio, pois o espaço desse ícone feminino é real para muitos e símbolo conceitual para outros, sendo sobrevida criacional em Dante. É verdade que muito se discute sobre sua existência real, porém o que se tem são elementos históricos que atestam seus comentadores desde lacopo Alighieri, filho de Dante, a Boccaccio, que, sem dúvida, foi um dos mais argutos e convincentes no que tange a essa existência e que alude a uma parenta de Beatriz como sua referência direta. Acerca disso, Valli (1994, p.320) discute o papel da crítica realista que acredita nos dados apresentados por Boccaccio no que diz respeito à real existência de Beatriz.

Boccaccio coloca em discussão a veracidade sobre Dante fazer parte de uma seita amorosa, aquela dos fiéis do amor. Como conhecedor e fiel seguidor dessa seita, o autor de Decameron jamais falaria da Beatriz que Dante pinta; tal hipótese teria como propósito intencional o de confundir o futuro leitor.

A insistência acerca da existência de uma possível Beatriz real, como modelo seguido pelo poeta, não é matéria nova dentro da crítica dantesca que se debruça entre estudos de filologia e crítica literária para torná-la compreensível do ponto de vista poético; isso faz-nos recorrer à historiografia como tentativa para entendermos um elemento que é apresentado de modo complexo; deve-se entender antes de mais nada o que norteia o campo ideológico de Dante no período medieval, ou seja, a ciência fundamentada em bases teológicas, dado por si só capaz de justificar algumas decisões do poeta inserido num contexto de profunda dominação do pensamento filosófico-cristão.

A partir dos estudos iniciados por Corrado Bologna, Molli (2010, p. 11) analisa Beatriz como uma mola mestra, presente desde as composições juvenis até a Comédia, sendo que tal premissa é compartilhada por Luigi Pietrobono e Thomas Stearns Eliot. Ainda de acordo com Molli, essa mulher está imersa em certa divinização cabalística que se justifica na exegese ordenada pela tradição bíblica (MOLLI, 2010, p.11). 
A existência de Beatriz, tida como figura historicamente real, deve passar primeiramente pelo filtro da concepção poética de Dante, pois se sua obra opera a partir de elementos alusivos, a presença real de Beatriz deve ser discutida. Para tanto, deve-se levar em consideração os elementos que entram nessa nova maneira de poetar, e também a relação de profundo afeto do poeta com sua musa, que não nos limita a torná-la real caso seja necessário, conforme ressalta Auerbach:

Per la nostra indagine è indifferente sapere chi era Beatrice, e se essa sia vissuta davvero; la Beatrice da Vita Nova e della Commedia è una creazione di Dante e non ha quasi a che fare con una giovane di Firenze che più che tardi sposò Simone de Bardi. E se essa d'altro canto è niente più che una allegoria di mistica sapienza, resta in lei tanta realtà e personalità che si ha il diritto di conoscerla una figura umana, che possono o non quei dati di fatti reali riferirsi ad una persona determinata ${ }^{73}$.(AUERBACH, 2009, p.55)

Não podemos pensar em paralelos absolutos quando tratamos da poesia de Dante, uma vez que ele reorganiza um conjunto de experiências poéticas anteriores que passam por um processo de filtragem, que imprimirá a sua obra um caráter inovador, importante por estabelecer paralelos comparativos que podem confundirnos enquanto leitores, uma vez que suas referências são várias, e pautam-se antes, pelo desejo incansável de inovação. Isso pode ser apreendido em suas rimas complexas, que se atrelam a elementos retóricos, os quais exigem uma poesia com fundamento no replicatio, evidenciando uma mente que se insere com profundo zelo e dedicação, capaz de reelaborar conceitos anteriores, atribuindo-lhes, segundo Petrocchi, novas características (PETROCCHI, 2008, p.35).

O valor poético atribuído coloca Beatriz em uma plataforma de suprema distância humana, o que talvez justifique a sua não aceitação real como elemento de direcionamento dessa poesia, uma vez que o modelo humano seria infiel à sua proposta, pois a poesia de Dante é uma poesia de louvor.

\footnotetext{
${ }^{73}$ Para nossa indagação é indiferente saber quem era Beatriz e mais ainda se ela viveu realmente; a Beatriz da Vida Nova e da Divina Comédia é uma criação de Dante e não tem relação com uma jovem florentina que se casou com Simone di Barbi. Essa mulher é nada mais que uma alegoria da mística sabedoria, mas permanece nela uma aparente personalidade humana que temos o direito de vê-la cheia de toda humanidade, por mais que os fatos reais possam ou não referir-se a uma pessoa determinada. (Tradução nossa).
} 
Beatriz, neste contexto, apresenta-se em contínua lapidação até firmar-se como espécie de guia, que revelará os mistérios da alma. Uma mulher que se sublimou, pois ao desvelar seus mistérios sublimes perde a condição humana, tornando-se "alegoria" da filosofia, da sabedoria e da ciência do sagrado e que ao chegar ao paraíso, explica-nos os seus mistérios (ROUGEMONT, 2006, p 232).

Em Donna ch' avete intelletto $d^{\prime}$ amore (Vida Nova, XIX, 6), Dante demonstra, além do grande talento, uma escrita voltada a uma mulher que se torna a única razão da sua produção, conforme fica evidenciado no verso, ma ragionar per isforgar la mente (Vida Nova, XIX, 8). Em contrapartida em Amor per tal ragione sta'n cor gentile (Rime; Guinizzeli), produção ainda influenciada pela linguagem guinizelliana, encontramos uma elevada consciência desse movimento de ideias e de técnicas literárias que Petrocchi (2008, p.37) diz não serem totalmente novas. Todavia, as rimas são novas em sentido absoluto dentro da poesia florentina.

O amor de Dante por Beatriz é importante não só para fundamentar um novo estilo, mas um momento no interior da poesia em que a mulher constitui elemento geral do verso. Para essa mulher, Dante cria uma poesia que intensifica a beleza e a dedicação ao gênero. A Vida Nova será o ponto de nascimento da presença feminina em Dante, pois Beatriz é talvez a única a ditar as regras, traçar um caminho que será seguido por outras mulheres. A propósito disso, as palavras de Gorni (2009, p.110) são brilhantes ao reconhecer a Vida Nova como o livro de Beatriz por antonomásia.

A narração dos poemas da Vida Nova marca um período de intensa reflexão na vida de Dante. Após a morte de Beatriz, o poeta narra em primeira pessoa ${ }^{74} 0$ encontro com aquela que será a mola propulsora da sua poesia. Organizado em forma de prosimetro, o poema tem correspondência com modelos elaborados desde Agostinho, Boécio, dos razos provençal, dos trovadores presentes em cancioneiros occitânicos, até aqueles cuja temática é ligada à vida dos santos. Mesmo tendo

\footnotetext{
${ }^{74}$ Petrocchi $(2008$, p.40) Sobre a crítica textual moderna, no que concerne à Vida Nova, Pertocchi traz um estudo, sobretudo de Althusser onde este diz que no momento em que direciona o exame dos textos partindo de uma abstrata teorização, encontra-se na Vida Nova a presença de diferentes níveis de enunciação: um primeiro que ele chama de processo de intercessão, ou seja, a vida do indivíduo narrante, chamado de eu narrador, que se encontra com a vida de uma figura, no caso Beatriz. Neste momento há o nascimento linguístico do sujeito em dimensão quotidiana e cosmológica.
} 
surgido como um modelo cheio de intensa novidade, ele serve para garantir a Dante um caminho, usado por Dante para construir um espaço novo, através de sua capacidade de polir o verso que aturde qualquer leitor moderno, que se encanta com esta grandeza.

Os poemas: Per una ghirlandetta (Rime: X) Deh, Violetta, che in ombra d' amore (Rime: XII); gentil donne (Rime: XIII, XXIII); Due donne in cima de la mente mia (Rime: XXXIII); I' mi son pargolettta bella e nova (Rime: XXXIV); Perchè ti vedi giovinetta e bella (Rime: XXXXV); Tre donne intorno al cor mi son venute (Rime: XLVII), imersos em um período de tentativas ainda experimentalista, aprensetam rimas, que segundo Maurizio Perugi (1995, p.LVII), demonstram a técnica que em Dante é matéria sacra, exercício ascético que caminha para a perfeição, apresentando certa variedade de estilos que têm um profundo significado e se fundem em um conjunto que exprime uma nova ideia de mulher.

Importante frisar que as poesias citadas acima descrevem mulheres de modo bastante impessoal, desprovidas de aparente personalidade; elas aparecem como representações alusivas ao universo feminino, sendo marcas da busca de Dante pela caracterização dessa nova poesia.

Os modelos femininos, que por ventura aparecem, estão sempre atrelados à figura de Beatriz; a mulher que não apresente relação com a musa de Dante está fadada a cair no esquecimento. Além dela, nem mesmo Gemma Donati, esposa do poeta, é digna de ser citada nas suas obras. O poeta isola qualquer possibilidade de ter falado de outra mulher além de sua musa, conforme os versos: io spero di dicer di lei quello che mai non fue detto d'alcuna ${ }^{75}$ (VN: XLIII, 3).

Na poesia Per uma ghirlandetta ch'io vidi (Rime, X), o poeta esboça uma imagem muito ligada à comparação entre a mulher e a "flor". De fato, o poeta estabelece, ao longo da sua poesia, uma relação próxima com esse conceito de "flor", que se desdobra em nomeações específicas como, por exemplo, girhlandetta, Fioretta, entre outras, e que no poema estão ligadas à ideia do feminino.

Em DC, Alighieri fará uso constante do sintagma "flor", tanto para colaborar no processo de rima, quanto para justificar alguns fatos tutta impregnata da l'erba e dal

\footnotetext{
${ }^{75}$ Eu espero dizer dela aquilo que não foi dito a nenhuma outra. (Tradução nossa).
} 
fior (Purgatório: XXIV 147); Così dentro uma nuvola di fiori (Purgatório: XXX 28); per fratta nube, già prato di fiori (Paraíso: 80); e d'ogne parte si mettien ne'fiori (Paraíso: XXX., 65); Ond' io appresso: O perpetui fiori (Paraíso: 22).

Essa poesia imersa nas imagens naturais, com vocábulos ligados à natureza, propicia leveza ao estilo, sendo o sintagma "flor" profundamente poético; sua imagem e definição tem um valor de pertencimento à poesia. Aristóteles, na arte poética, assim define as palavras que têm uma profunda relação com a poesia: Definisco parola piacevole quella che ha ritmo e musica ${ }^{76}$ (BARABINO,1999, p. 15).

Contini (2003, p.31) analisa o vocábulo ghirlandetta, no percurso de Dante, entrelaçando à imaginação poética a sua apresentação discursiva. Importante notarmos a ligação da obra dantesca com a figura feminina, como Lia (personagem da Divina Comédia), que se apresenta como aquela que produz de forma manual a ghirlandetta: sappia qualunque il mio nome dimanda/ ch'i' mi son Lia/ e vo movendo intorno le delle manil a farmi una ghirlandetta ${ }^{77}$ (Purgatório: XXVII,100-102).

Nos versos Fioretta mia bella a sentire/ allor dirò la donna mia, o poeta exalta a beleza da mulher, numa comparação com esta "fioretta".O poema está permeado, como toda composição dantesca, de um esquema místico não revelado, cujas questões ligam-se ao grupo dos "fedeli d'amore", que no ambiente da correspondência marcam rimas que caminham para inovação.

O experimento dessas novas rimas, elaboradas por Dante, apoia-se no âmbito pastoral, importante por caracterizar a precoce fase intermediária entre fiore e influxo Cavalcantiano, descrita por Perugi, na qual os elementos particulares do universo poético buscam suporte na natureza para instrumentalizar a sua produção, já presentes em Guido Cavalcanti, precursor dessas imagens (Perugi apud CONTINI, 2003, pp. 30-32), que se constituem, por sua vez, em dados que moldarão e revestirão a poesia dantesca. Assim, Alighieri cria o conceito de palavras ornadas, que ocupam espaço mágico dentro desse repertório, conforme os seguintes versos,

\footnotetext{
${ }^{76}$ Defino como palavra agradável aquela que possui ritmo e música. (Tradução nossa).

77 Saiba quem quer o meu nome demanda, Lia ser eu e vou movendo em torno as belas mãos uma guirlanda. (Tradução Vasco Graça Moura).
} 
Le parolette mie novelle che di fiori han ballata, per leggiadria ci hanno tolt' elle una vesta ch'altrui fu data (Rime: X., 19-21).

Uma nova roupagem dá o tom que encaminha o universo da poesia estilnovista, e aqui apontamos para "leggiadria" por se constituir em uma relação de elegância e fineza no processo de composição. Chiavacci (2007, p. 780) afirma que o termo apresentava relação com uma virtude específica que fazia parte de um homem envolto no universo da corte, sendo que Dante faz referência ao termo, quando encontra Guinizzelli, vejamos:

quand' io odo nomar sè stesso il padre

mio e de li altri miei migliori che mai

rime d'amore usar dolci e leggiadre ${ }^{78}$ (Purgatorio: XXVI, 97-99)

Já no poema:

Deh, Violetta, che in ombra d'Amore

negli occhi miei sì subito apparisti,

aggi pietà del cor che tu feristi,

che spera in te e disiando more.

Tu, Violetta, in forma più che umana,

foco mettesti dentro in la mia mente

col tuo piacer ch'io vidi;

poi con atto di spirito cocente

creasti speme, che in parte mi sana

${ }^{78}$ Quando a si mesmo ouvi nomear o padre/ meu e de uns melhores que alegres sei/ usarem doce rima que a amor quadre. (Tradução de Vasco Graça Moura). 
la dove tu mi ridi.

Deh, non guardare perché a lei mi fidi,

ma drizza li occhi al gran disio che m'arde,

ché mille donne già per esser tarde

sentiron pena de l'altrui dolore.

Pode-se notar a construção e descoberta de uma imagem de mulher, cuja nomeação ainda passa pelos elementos que compõem o universo lírico do poeta, ou seja, é impossível para Dante uma revelação de nomeação, salvo o soneto Guido vorrei che, no qual as figuras nomeadas são a princípio elementos que justificam a relação Guido e Lapo.

Dante, por sua vez, não revela o nome da sua amada, apenas sugere con quella ch'è sul numer de le trenta; talvez sua fidelidade a um estilo, envolto por palavras ornadas, impeça uma possível nomeação dessa mulher, sendo que todo esse esquema é fruto da tradição que o poeta segue com intenso zelo. De acordo com Marina Zancan (1998, p.10) uma classificação da mulher como possível destinatário dos versos em língua vulgar equivaleria à perda do nível simbólico da poesia, fruto do novo pensamento e da nova tradição poética.

Dante não abandona as marcas dessa tradição poética, apresentando como referencial uma poesia de fontes greco-latinas, sendo que as indicações emergem de dentro da sua Comédia. Alighieri absorveu durante toda a sua vida uma cultura de clássicos, num período de profunda redescoberta destes, carregando consigo qualidades imensas que na grandeza da obra, A Divina Comédia, o discurso em afirmar ter buscado nos clássicos a fonte e più d'onore ancora assai mi fennol ch'e' sì mi fecer de la loro schieral sì ch'io fui sesto tra cotanto senno ${ }^{79}$ (Inferno: IV,100102). Considerar as marcas do tempo e da cultura literárias, que impuseram ao poeta um estilo, é fundamental, e como ressalta Pazzaglia (1998, p. 28) essencial para compreender a sua mensagem, dentro de um universo marcado pela inovação.

\footnotetext{
79 [...] e me fizeram inda honras maiores/ porque assim me chamaram à fileira/ e fui sexto entre tantos sabedores. ( tradução de Vasco Graça Moura)
} 
A poesia imersa nos conceitos filosóficos ganha vida para explicar o conceito "donna", sendo que os versos Tu, violetta, in forma più che umana, foco mettesti dentro in la mia mente (Rime X., 5-6) já apresentavam uma metamorfose da mulher, e a ideia de forma mais que humana remete-nos a pensar num processo de divina apresentação que culminará na elevação a "donna angelo", ou seja, Beatriz.

Ainda no campo das imagens, no que se refere à mulher, há um frequente uso da palavra "gentil" (che per le gentil donne altrui martira (Rime: XIII, 5)), talvez como alusão a uma noção de limitação, ou seja, não é a qualquer mulher que o poeta se dirige, mas àquela que tem em si amor e gentileza como elementos equivalentes. Sanguineti $(1999,34)$ esclarece que o enunciado "cor gentil" explica o fundamento amoroso dos poetas do doce estilo novo e que já podemos encontrar uma referência em Guinizzelli, mais especificamente na canção Al cor gentile repara sempre amor.

A relação que se estabelece no interior da poesia de Dante centraliza a mulher como matéria necessária e única no processo de composição; essa presença anima o espírito do poeta que a tem como força e elemento motriz do processo intelectual, sendo anterior à poesia. No entanto, o papel dessa mulher, no movimento dos poetas estilnovistas e nas poesias, em análise, está longe de uma revelação direta. Em Deh Violetta (Rime, XII, 1) o poeta usa um qualificativo referencial que mesmo assim permanece como uma lacuna nominativa.

O estudo efetuado por Gorni (2009), que parte da ordenação rigorosa pensada por De Robertis, leva em conta as formas métricas e de cronologia com o objetivo de demonstrar que essa balada seria de atribuição dúbia. Em contrapartida, Petrocchi (1999, p.34) traz à discussão a possibilidade de Violetta (Rime, XII) e Fioretta (Rime, $\mathrm{X}, 12$ ) serem a mesma "pessoa", sendo "Fioretta", por análises de datação e estudos das rimas, umas das "donna del schermo" presentes na Vida Nova. Essa novidade apontada por Petrocchi encontra relação direta com o pensamento de Valli, vejamos:

Altro stranissimo fatto che accade nella poesia dei "fedeli d'amore", ma non in genere agli innamorati, è di avere come confidenti e

\footnotetext{
${ }^{80} \mathrm{O}$ uso do adjetivo gentil ligado à mulher aparece também em outros poemas do conjunto de rimas de Dante, de modo que a análise não se limita pontualmente ao nosso recorte.
} 
intermediarie nel loro amore certe numerose, incompresibili, e molto indefinite "donne", alle quali il poeta si rivolge e si raccomanda nelle circostanze più varie e le quali prendono lume e splendore da quella tale "donna sovrana ${ }^{81 "}$.(BALLI, 1994, p.71)

soneto Due donne in cima de la mente mia (Rime, LXXXVI, 1) traz à discussão, a tradição alegórica de Dante, que tem nessa aparição certa perspectiva de disputa metafórica, fictícia, antecipando, segundo Contini (1995, p. 111), a matéria desenvolvida em Tre donne intorno al mio cor mi son venute (Rime, CIV), bem como propondo uma poesia de caráter figural, na qual o enunciado dispõe de um complexo emaranhado de significação, ou seja, o objeto da enunciação liga-se a outros referentes, interpondo um segundo significado,

La interpretazione figurale stabilisce fra due fatti o presone un nesso in cui uno di essi non significa soltanto se stesso, ma significa anche l'altro, mentre l'altro comprende o adempie il primo. I due poli della figura sono separati nel tempo, ma si trovano entrambi nel tempo, come fatti o figure reali ${ }^{82}$ (AUERBACH, 2009, p. 209).

Em Tre donne intorno al mio cor (Rime, CIV), o amor é apresentado como matéria central, um amor que ultrapassa a compreensão, a partir de um novo conceito, um "eros" que reconheceu e integrou novos conteúdos éticos e filosóficos, além de trazer uma referência direta ao conceito feminino. Essa poesia parte de uma tradição poética já presente em "três tosas", protagonista de Lo doutz chans de Giraut Perugi (1995, p, xxxi), cuja linguagem ornamenta-se de elementos que aludem aos conceitos presentes na esfera filosófica, na qual a mulher será um elemento sugestivo.

As apresentações femininas na lírica dantesca partem de um conjunto de experiências poéticas que se fundamentam antes na busca pelo experimentalismo e que ganham espaço graças à liberdade que o poeta tem de escrever na sua língua

81 Outro estranhíssimo fato que ocorre na poesia dos "fiéis do amor", mas não em relação aos apaixonados, e que têm como confidentes e intermediários nas suas relações amorosas, estranhas mulheres, incompreensíveis e indefinidas "mulheres", às quais o poeta se volta e recomenda nas diversas circunstâncias as quais ganham luz e esplendor, a partir daquela mulher soberana. (Tradução nossa).

${ }^{82} \mathrm{~A}$ interpretação figural estabelece entre dois fatos ou pessoas um nexo no qual um destes não tem significado apenas em si mesmo, mas significa também o outro, enquanto o outro compreende ou completa o primeiro. Os dois polos da figura são separados no tempo, mas se encontram ambos no tempo. (Tradução nossa). 
local, sendo que, segundo Malato, poetar nessa língua vulgar era, por ordem, escrever poesias amorosas (MALATO,1995, p. 816). 


\section{MULHERES ADVERSAS OU ANTÍPODAS A BEATRIZ}

As aparições femininas, no corpus das rimas extravagantes de Dante, conceito definido por Contini e Gorni, para designar aquelas produções que estão fora da Vida Nova, apresentam diferentes mulheres como resultado de muitas experiências poéticas anteriores de Dante, e culminam na transformação desses modelos no conceito de angelização, requerendo cuidado na aparição de outra(s) figura(s) feminina(s), que não sejam Beatriz, já que existiram outras mulheres, ou pelo menos outras ideias de mulheres diferentes dela na poesia juvenil de Dante, antes da Vida Nova.

A ideia de transformação da condição feminina de mulher real para mulher angelical não é exclusivamente patente da escola da qual Dante fez parte, o doce estilo novo, responsável por imprimir na poesia essa temática de modo mais arguto e eficaz. Vale lembrar que poetas da escola siciliana e, também os chamados sículos-toscanos, já haviam introduzido na poesia italiana a noção de elevação da mulher.

Guittone D’Arezzo ${ }^{83}$, poeta da escola sículo-toscana já vislumbra em Guido Guinizelli uma poética de louvor à mulher, que posteriormente será aproveitada por Dante e Guido Cavalcanti, com maior intensidade. No poema Spietata Donna e fera, ora te prenda, Guittone, um fiel cultor do trovar clus provençal (maneira áspera e com rimas duras), dá espaço às poesias amorosas com características de louvor ao feminino conforme vemos nos seguintes versos:

Spietata Donna e fera, ora te prenda

Di me cordoglio, poi morir mi vidi:

Che tanta pietà di te discenda,

83 Guittone D'Arezzo natural de Arezzo região da Toscana, foi uma das personalidades mais relevantes que compunha o grupo dos poetas da fase sículo-toscana da poesia italiana. Escritor na sua grande maioria de poesias da segunda fase da produção lírica dos duzentos, sobre moral, vida civil e política. Seu cancioneiro é um dos mais amplos da época. 


\section{Che'n alcuna misura meve fidi $i^{84}$}

Como podemos notar, a poesia do frei Guittone D’Arezzo já demonstra um léxico particularmente voltado à ideia de contemplação da mulher. Referências bíblicas permeiam não seu universo poético, mas também o de Guido Guinizelli, ambos responsáveis por legar à mulher a condição de ser sublime, cujas características aproximam-se das atribuídas à virgem Maria.

Como fonte de inspiração e modelo poético, a mulher, ao longo da trajetória da poesia, constitui-se em um elemento necessário para seu artífice, o poeta. Importante ressaltar que o trovadorismo já exprimia, de forma bastante clara, o papel que a mulher exercia nas relações e, de modo venal, naquela amorosa, pois, ao longo da sua história a sujeição feminina à condição de provocadora do pecado direcionará na poesia a uma construção de Eros, equivalente à filosofia cristã.

Entender essa sujeição, bem como a reformulação feita com Eros pelo cristianismo, são essenciais para se compreender como ocorre a transformação da mulher, na poética de Dante Alighieri. A tese mais corrente, acerca da modificação do lócus de Eros carnal para aquele idealizado pelo pensamento cortês, vem melhor definida por Rougemont, que assim esclarece: Potremmo limitarci a ricordare che il simbolismo medioevale procede generalmente dall'alto al basso - dal cielo in terra ${ }^{85}$ - o autor cita a noção pensada por Wechssler de que, grosso modo, a lírica provençal é uma expressão do sentimento religioso da sua época.

Portanto, a sujeição de Eros, a um conceito desligado da satisfação corporal, encontra justificativa no pensamento cristão e na relação estabelecida pela poesia trovadoresca ligada a correntes místicas da época. Desse modo, tal arte não se enquadra no espírito da corte feudal ou mesmo dos cantos Calendimaggio, como pensavam algumas correntes críticas; essa poesia tem maior aproximação com 0 pensamento Templário e aquele dos Albagineses (VALLI, 1994, p. 175).

${ }^{84}$ Cruel e ferida mulher/ tenha por mim compaixão, pois me vistes morrer/ seja piedosa de algum modo/ pois em ti confio. (Tradução nossa).

${ }^{85}$ Limitemo-nos a recordar que o simbolismo medieval procede geralmente do alto para o baixo, ou seja, do céu para a terra. (Tradução nossa). 
Na sua fase juvenil, a poesia de Dante Alighieri, especificamente a de cunho experimentalista, composta, principalmente, pelos poemas da Vida Nova e também aqueles de rimas extravagantes, apresenta diferentes possibilidades de aparição de outras mulheres, que não apenas a sua musa predileta.

Nesse contexto, as repetições lexicais apresentam um Dante engajado com a poesia e sua temática, ambas voltadas à mulher, constituindo-se em elementos retirados da fantasia guinizelliana, inventor de uma verdadeira poética, que une de forma análoga o objeto amado às formas naturais. Sobre isso Ghetti expõe,

Guinizzelli è insomma l'originale inventore di uma vera e própria poetica dell'analogia tra l'oggetto amato e le forme naturali, chiamate a fare da corona all'evento amoroso, con um movimento della fantasia che a tratti ricorda, più che i modi provenzali e siciliani, quelli della lirica erótica araba. Gli uccelli, i fiori, il sole, le stelle, le gemme preziose, gli elementi della natura sono belli perchè sono "segni" visibili della bellezza della donna ${ }^{86}$. (GHETTI, 2010, p.79)

Ainda sobre a noção lexical, vale lembrar que a repetição frequente desses vocábulos característicos, internos à poesia estilnovista não são "governados" por princípios igualitários, conforme pensamento de Patrick Boyde,

La ripetizione di unità lessicali all'interno di una poesia o di un gruppo di poesie non è naturalmente governata da principi "egualitari". Certe parole sono ripetute frequentemente, altre non sono ripetute affato. É plausibile, per di più, che una significativa relazione esista tra le preoccupazioni, i fini e la personalità di un autore, e le parole - le parole "oggetto" - che egli usa più spesso ${ }^{87}$. (BOYDE, 1979, p.133)

Essa presença de vocábulos específicos, dentro da produção lírica do poeta, ajuda-nos a compreender as imagens e as recorrências de que ele fizera uso na construção da imagem do feminino. Como bem afirma Contini, nas rimas de Dante, o

\footnotetext{
${ }^{86}$ Guinizelli é, em suma, um inventor original de uma verdadeira e própria poética da analogia entre objeto amado e as formas naturais, coroas do evento amoroso, com um movimento da fantasia que pelo tratamento recorda, mais os modos provençais e sicilianos, aquelas da lírica erótica árabe. Os pássaros, as flores, o sol, as estrelas, as gemas preciosas, os elementos da natureza são belos porque são sinais visíveis da beleza da mulher. (Tradução nossa).

87 As repetições de unidades lexicais no interior de uma poesia, ou grupo de poesias, não é naturalmente governada por princípios igualitários. Certas palavras são repetidas frequentemente, outras não são repetidas de fato. E bastante plausível que uma significativa relação exista entre as preocupações, os fins e a personalidade de um autor, as palavras - palavras objetos - que são usadas constantemente. (Tradução nossa).
} 
problema das aparições femininas torna-se um assunto complexo e cansativo (CONTINI, 1997, p.303). Em contrapartida, Gorni, dantista contemporâneo, após um criterioso estudo, que separa e organiza a obra de Alighieri por temas, pontua que Beatriz talvez não seja a única inspiradora hegemônica nas rimas, podendo haver outros vultos femininos a acompanhar Beatriz em seu caminho.

As manifestações femininas nos poemas, que compõem o conjunto das rimas extravagantes, são descritas por diferentes prismas. A crítica moderna (de Barbi e De Robertis até Contini) aponta outras aparições femininas, a exemplo da Donna Angelo, Donna Schermo; tipos evidentemente diferentes da figura de Beatriz, construídas segundo as intenções do poeta, são importantes, por sua vez, na demonstração da profunda relação que há entre poesia amorosa e o conceito feminino.

Em seu noviciado poético, Dante lapidou a ideia de um feminino único, dando vida a um conceito já presente na obra de seu primeiro amigo, Guido Cavalcanti, que, a partir da forma metafórica e simbólica, aponta para um conceito de elevação feminina. Em Fresca rosa novela/ piacente primaveral avete in voili Fiori e la verdura Cavalcanti esboça o processo de elevação da mulher, construindo imagens que propiciarão a Dante o caminho para conceitualizar e nomear a sua donna angelo.

Essa busca pela perfeição feminina é sentida no célebre fim da Vida Nova em que o poeta reverbera os ecos de anos de polimento desse conceito, propondo narrar sobre sua musa o que jamais ninguém disse sobre nenhuma outra. Tal necessidade, surgida a partir dos seus contatos com diferentes escolas poéticas bem como, ideologias diversas, as palavras de Benedetto Croce, acerca do Dante jovem, convergem para pensarmos em um profundo aprendizado poético, tendo como resultado uma poesia perfeita ${ }^{88}$.

É notável que Dante segue, com intenso zelo, os passos de Guido Cavalcanti buscando, às vezes, emular o que já se apresenta na poética

${ }^{88}$ Croce (1957, pp. 27 e 28) afirma que Dante, quando jovem, cultivou uma jovem literatura, também procurou trilhar os caminhos dessa literatura, certo de que já a tinha achado, quando na verdade trilhou apenas uma pequena parte desta. Ele se uniu antes a uma escola literária recentemente iniciada na Itália, aquela do amor que tem relação direta com a ideia de coração gentil e com o louvor à mulher concorrente a criatura celeste, a anjo. O poeta foi em geral na sua idade juvenil aluno fiel, criou a sua mulher anjo, a qual pos o nome Beatriz significando com isso o resultado final do seu período de aprendizagem poética. 
cavalcantiana, em especial, no que concerne à noção de angelização da imagem feminina. Guido apresenta uma ideia de feminino incompreensível pela mente, uma mulher com semblantes de elevação à condição divina,

\author{
Angelicata sembranza \\ in voi donna, riposa \\ Dio, quando aventurosa \\ fue la mia disianza ${ }^{89}$
}

Cavalcanti impõe a Dante a concessão de louvor à figura da mulher, apresentando novas imagens para conceituar a noção amorosa. De acordo com Ghetti, Guido cria um pensamento verbal específico, importante para apresentar uma realidade feita de imagens naturais e físicas (GHETTI, 2010, p.96). No decorrer da tradição lírica, e isso já é sabido, a mulher torna-se matéria central, sendo que o poeta apenas reformula a matéria temática, dando novos horizontes. A este propósito Marina Zacan (1998, p.7) afirma:

La figura femminile, che è II perno intorno a cui ruota il pensiero e si costruisce il componimento poético, svolge la funzione di rappresentare un processo di raffinamento di costume e di cultura, che attribuisca valore al soggetto di enunciazione. La donna reale, in questa realtà intelletuale, non ha parte alcuna, non è in sé parte del discorso poético; è la figura che consente la resa, in una immagine a misura d'uomo, di un pensiero che attesta il valore della propria funzione ${ }^{90}$. (ZACAN, 1998, p.7)

Na perspectiva desse novo horizonte, Dante constrói um universo particular para a mulher, no qual há certo amadurecimento da noção de elevação máxima de

\footnotetext{
${ }^{89}$ Angelical semblante/ em você, mulher, repouse/ quanta aventura/ houve na minha esperança. (Tradução nossa).

${ }^{90}$ A figura feminina, que é ponto chave e gira todo o pensamento e onde se funda o pensamento poético, desenvolve a função de representar um processo de refinamento de costumes e de cultura, que atribua valor ao sujeito de enunciação. A mulher real, nesta realidade intelectual, não faz parte em nenhum momento, não é em si parte do discurso poético; é a figura que consente essa realidade, uma imagem do tamanho do homem, de um pensamento que atesta o valor da própria função. (Tradução nossa).
} 
um ser carnal ${ }^{91}$ para a condição divina. Essa transumanização justifica-se na sabida elevação de Eva à condição de mulher redimida, metaforizada na figura da virgem Maria e no espaço que os seus antecessores concedem à poesia cuja característica particular encontra-se no léxico proveniente da filosofia mariana.

As imagens que concorrem para a transformação da ideia feminina real em uma evidentemente ligada ao culto mariano estão presentes em quase todos os poemas das Rimas e povoam de forma absoluta aqueles que compõem o Prosimetro $^{92}$ da Vida Nova. Nossa análise de apontamento dessa noção baseia-se, principalmente, nos poemas chamados de extravagantes, uma vez que tais textos apresentam um Dante ainda em processo de construção do conceito de louvor à figura feminina, conforme notamos nos seguintes versos:

\author{
Madonna, quel signor che voi portate \\ ne gli occhi, tal che vince ogni possanza, \\ mi dona sicuranza \\ che voi sarete amica di pietate ${ }^{93}$
}

O uso do substantivo "madonna", por exemplo, já está presente na poesia de Guinizzelli, porém convém lembrar que esses substantivos e as construções em que eles aparecem espelham a tradição da poesia trovadoresca. De acordo com Patricky Boyde:

Si potrebbe dire perciò che la poesia trobadorica non sarebbe stata cio che è senza quei sostantivi e le costruzioni in cui essi appaiono. Noi possiamo considerare questi nomi e queste costruzioni essenziali

\footnotetext{
${ }^{91}$ Auerbach (2009, p. 31): na poesia provençal a mulher permaneceu pelo menos a princípio, um ser terreno, Guinizelli foi o primeiro que ousou representá-la como mediadora da suma graça e do conhecimento e criou um novo aparato teórico que a mudança exigia. (Tradução nossa).

92 Modelo de produção poética antecedida por um comentário em prosa.

${ }_{93}$ Mulher, aquele senhor a quem trazes/ nos olhos, que vence qualquer dominação/ me doa segurança/ e vos que serás amiga da piedade. (Tradução nossa).
} 
alla concezione che i trovadori avevano dell'amore e dei suoi effetti sull'amante $^{94}$. (BOYDE, 1971, p.102)

O universo da poesia amorosa dos estilnovistas envolve-se em absoluto com aquele filosófico cristão, tendo como resultado a aparição de uma mulher com novas características, quase símile à imagem de Maria. Além de celebrar uma mulher homônima a Maria, os atributos e a relação do uso vocabular, bem como sua relação temática direcionam ao culto mariano, o que nos leva a pensar, grosso modo, em uma grande mudança no conceito de feminino, mudança, pode-se dizer, absoluta no período de aprendizagem poética de Dante.

É verdade que o problema das muitas mulheres em Dante é parcialmente resolvido com a fase de construção da sua Vida Nova, obra cuja temática delimita a figura de Beatriz como protagonista central. Anterior ao prosimetro, outras aparições femininas pareciam distanciar-se da figura de Beatriz, mulher que compõe todo o imaginário dantesco e também povoa a ideia universal de mulher. Ela seria o próprio Dante no seu mais alto grau de perfeição poética, conforme Mario Pazzaglia:

Beatrice e la "vita nova" quali sono esemplate dal libro giovanile rappresentano il primo formularsi d'un mito poético che arricchirà progressivamente la propria valenza col suo successivo sviluppo artistico, culturale, spirituale del poeta; con la sua sempre più decisa volontà di attingere con la poesia un più universale messaggio ${ }^{95}$. (PAZZAGLIA, 1998, p.6)

Outro aspecto importante para compreender manifestações femininas, dentro do quadro lírico dantesco, encontra-se no uso frequente de figuras retóricas e também no uso do processo de linguagem alegórica. Maurizio Perugi (1939, p.8) ressalta a consistência literária e alegórica dos personagens femininos que se dá a

${ }^{94}$ Pode-se dizer que a poesia trovadoresca não seria a mesma sem aqueles substantivos e as construções em que esses aparecem. Podemos considerar estes nomes e estas construções essenciais à concepção que os trovadores tinham do amor e dos seus efeitos sobre o amante. (Tradução nossa).

${ }^{95}$ Beatriz e a Vida Nova como exemplificada no seu livro juvenil, representam a primeira formulação de um mito poético que enriquecerá progressivamente o próprio valor e com seu sucessivo desenvolvimento artístico, cultural e espiritual do poeta, com a sua evidente vontade de atingir com a sua poesia uma mensagem universal. (Tradução nossa). 
partir de Beatriz, e tal elemento é importante para demarcarmos uma pontual diferença no que tange às mulheres nas rimas dantescas.

As profusões de imagens léxicas alusivas às mulheres nas rimas do poeta florentino indicam-nos que no universo poético de Dante coabitam com Beatriz outras mulheres. Em Di donne io vidi una gentil schiera (Rime, LXIX) é evidente a alusão que o poeta faz às mulheres diferentes de sua musa; o soneto marca um alto grau da experiência estilnovista, as indicações dessas outras presenças fundamentam essa escola, na qual a relação com o universo feminino é temática maior.

Nas canções Due donne intorno alla mia mente (rime LXXXVI) e Tre donne intorno al cor mi son venute (Rime, CIV), o poeta demonstra todo seu talento alegórico, sendo que as invocações presentes nos dois sonetos estão efetivamente ligadas à ideia do feminino. Segundo a crítica dantesca também é possível vislumbrar nessas composições a linguagem alegórica característica da época de Dante.

Além disso, é curioso notar a diferença estabelecida pelo poeta entre o substantivo donna e o substantivo femmina, que apresenta uma conotação pejorativa na poesia, uma vez que não é de qualquer mulher ${ }^{96}$ que o poeta fala na sua poesia, mas das mulheres que portam consigo gentileza. Etienne Gilson (1998, p. 24) afirma que as figuras femininas em Dante não são reais, sendo que para o historiador a omissão sistemática do termo fêmea apresenta a evidência de uma presença simbólica feminina na poesia dantesca.

As palavras de Dante, presentes nos poemas da Vida Nova, atestam o pensamento de Gilson, conforme fica evidenciado nos seguintes versos: Questa non è femmina, anzi è uno de li bellissimi angeli del cielo"97. Importante destacar que a diferenciação pensada pelo poeta acerca dos qualificativos "femmina" e "donna" tem

96 Edoardo Sanguineti (2001, p. 28) No capítulo XIX da Vida Nova compendiado pelo estudioso Edoardo Sanguinetti, Dante assim diz: dado que passando por um caminho longo o qual não havia uma Riva clara, me veio uma vontade de dizer e comecei a pensar em um modo e imaginei que falar dela não seria digno, se eu não falasse a mulheres em segunda pessoa, e não a cada mulher, mas àquelas que são gentis e que não são apenas fêmeas.

97 Esta não é fêmea, antes é um dos belíssimos anjos do céu. (Tradução nossa). 
justificação na própria tradição da poesia trovadoresca e na carga ideológica assumida pelo termo "femmina" ao longo da tradição poética.

Nos poemas que compõem a Vida Nova, a manifestação de uma noção feminina sublime já domina o pensamento poético de Dante; os qualificativos atribuídos à figura de Beatriz, ligados à filosofia cristã, especificamente ao culto mariano, refletem o processo de criação do feminino, que é transformado em um ser cheio de leveza, distanciado da ideia de um possível contato carnal entre o poeta e sua amada.

Ao longo do prosimetro, Dante direciona a sua poesia a outra mulher, bem diferente da sua Beatriz, conhecida como “donna schermo”, cuja notável aparição ao lado de Beatriz, conforme as próprias palavras do poeta:

Un giorno avvenne che questa gentilissima sedea in parte ove s'udiano parole de la Regina de la gloria, ed io era in luogo dal quale vedea la mia beatitudine; e nel mezzo di lei e di me per la retta linea sedea una gentile donna di molto piacevole aspetto, la quale mi mirava spesse volte, maravigliandosi del mio sguardare, che parea che sopra lei terminasse ${ }^{98}$.

Desse modo, confrontamo-nos com uma nova figura, diferente de Beatriz, que recebe do poeta os mesmos qualificativos da sua donna angelo. A narração é clara; a cena é de uma celebração litúrgica, constituindo-se em um ambiente propício para a apresentação de sua história, bem como para esclarecer a visão poética dantesca acerca da mulher.

Todas as aparições femininas nas rimas extravagantes e na Vida Nova refletem um Dante, criador de uma poesia que coroa a mulher como elemento fundamental, ou seja, para o poeta o universo lírico é, por natureza, composto pela presença feminina. Na sua fase adulta, a da composição da Comédia, Dante, mesmo imaginando uma poesia com características diferentes da sua formação lírica, introduz espaços onde o lírico amoroso e as mulheres têm lugar de destaque e fazem com que o talento poético de Alighieri brilhe ainda mais.

${ }^{98} \mathrm{Um}$ dia aconteceu que esta gentilíssima sentava em um lugar onde se ouvia palavras da rainha da glória, e eu estava em um lugar onde podia ver essa beatitude; entre mim e ela numa reta linha sentava uma gentil mulher de muito agradável aspecto, a qual me olhava várias vezes, maravilhandose o meu olhar que parecia que sobre ela pousava. (Tradução nossa). 
É justamente com o intento de demonstrar que a sua veia lírica e a construção da imagem feminina, elaborada ao longo da sua fase juvenil, não escapam nem mesmo na fase da construção da Comédia, e exemplificar a propensão a uma visão feminina fundamentalmente cheia de intensa poesia, que escolhemos duas aparições femininas na Comédia, a saber: a figura de Francesca da Rimini e Matelda, exemplos que figuram, a nosso ver, cheios da sua experiência estilnovista. 


\subsection{FRANCESCA DA RIMINI}

Na Divina Comédia, muitos são os cantos que trazem ao leitor sentimentos de piedade e compaixão; é o caso particular do Canto $V$ do Inferno no qual figura a história de amor mais lida e comentada ao longo do tempo, o canto de Francesca e Paolo.

Nos primeiros passos em solo infernal, no círculo segundo, parte que compõe a geografia espacial dantesca, a apresentação de tipos femininos marcados pelo pecado da luxúria pintam o quadro da narrativa e apresentam mulheres que, para Dante, macularam o mundo com o pecado carnal e, por ordem superior, estão fadadas à pena eterna.

Assim como em narrativas canônicas, a Divina Comédia apresenta alguns cantos que foram ao longo do tempo escolhidos e comentados mais intensamente. Pautados nessa máxima, a crítica dantesca debruça-se, particularmente, em torno do episódio amoroso entre os dois amantes Paolo e Francesca, buscando apontar elementos históricos capazes de explicar o triste fim desses dois amantes. Em linhas gerais, o canto $\mathrm{V}$ do Inferno é dedicado aos réprobos que fizeram do pecado da carne a razão do próprio amor.

As razões fundamentais da grande obra do poeta florentino, nomeada na edição veneziana de 1555, por Giolito e Dolce, de Divina, justifica a punição dos amantes, já que, a intenção de Dante era construir um poema com rigorosa relação entre Céu e Terra, buscando a redenção através da viagem pelos três mundos alémtúmulo: no Inferno, no qual encontramos as penas eternas; no Purgatório, a purificação; e no Paraíso, o encontro da profunda paz.

Nesses espaços bem determinados, Dante dialoga e observa figuras do seu tempo, ou mesmo fora dele, dando vida e força dramática ao seu poema escatológico. As aparições são muitas e, os tipos descritos pelo poeta compõem o universo das intenções do próprio texto, no qual mulheres e homens se apresentam de maneira e com funções diversas no decorrer da narração. 
Vale destacar que a Divina Comédia foi um texto amadurecido pelo poeta a partir da sua imersão nos estudos da filosofia e da experiência poética estilnovista, assim como da sua profunda relação com os poetas clássicos da literatura grecolatina, a exemplo de Virgilio, além do exílio, importante agente motivador da escrita.

A estrutura e personagens da Comédia têm uma notável semelhança com a Eneida de Virgílio que se torna guia de Dante, sendo que essas referências a textos de outros poetas da Antiguidade clássica, absorvidos por Dante, autenticam ainda mais a sua obra.

No que se refere à mulher a Comédia traz, nos seus três mundos, referências diversas. A obra, de fato, tem no seu conjunto personagens majoritariamente masculinos; as mulheres aparecem em menor quantidade. Entretanto é importante frisar que o universo de Dante foi composto na sua fase juvenil, nomeada estilnovista, devido à absoluta presença feminina. Essa afirmação pode ser atestada no final da Vida Nova, no momento em que Dante afirma que continuará a dizer de sua "donna" o que jamais tenha sido dito de nenhuma outra. De fato, Beatriz reaparece na Comédia, comprovando a frase final do prosimetro; ela clama por Virgilio, exortando-o a guiar Dante pelo Inferno e Purgatório, conforme os seguintes versos:

$$
\begin{aligned}
& \text { lo era tra color che son sospesi, } \\
& \text { e donna mi chiamò beata e bella, } \\
& \text { tal che di comandare io la richiesi. } \\
& \text { Lucevan li occhi suoi più che la stella; } \\
& \text { e cominciommi a dir soave e piana, } \\
& \text { con angelica voce, in sua favella9 (Inferno, II) }
\end{aligned}
$$

Beatriz surge como elemento central da obra, sendo a primeira aparição feminina da Comédia, ela é o anjo protetor do poeta, responsável em descer até o ${ }^{99}$ Sendo, entre os mais suspensos, eu ali/ uma senhora tão bela/ chamou-me e que mandasse Ihe pedi/ Luzia o seu olhar mais do que estrela/ e logo de dizer suave e Ihana/ na voz angelical que se revela (Tradução de Vasco Graça Moura). 
Limbo, lugar onde se encontra Virgílio, para lhe pedir que acompanhe Dante pelo Inferno. Além de guia, Virgílio é o encorajador daquele que sempre buscou nos seus escritos o exemplum.

A intervenção de Beatriz, assim como seu reaparecimento na Divina Comédia, atesta a forte recorrência a elementos da fase lírica de Dante. Elevada à condição de beata, Beatriz passa por um processo de transfiguração, ou seja, envolve-se em um novo véu significativo, assumindo características próprias da beatitude.

Essa primeira manifestação feminina na Divina Comédia, idealizada pelo poeta, responde ao anseio de Dante em conferir a ela a condição beatifica, por isso, a torna ponto central do processo de purificação pelos três mundos do além-túmulo.

Interessante notar que se na Vida Nova a musa do poeta apenas acena, saúda e olha, na DC o amor lhe concede voz para falar de onde veio, bem como o motivo da sua descida ao Limbo, conforme os seguintes versos:

I'son Beatriz che ti faccio andare;

Vengo del loco over tornar disio;

Amor mi mosse, che mi fa parlare ${ }^{100}$ (Inferno, canto II, 70-72)

Ao figurar como principal mulher na DC, a musa de Dante usa, quando referencia a sua relação com o poeta, tópicos característicos da poesia provençal, muito usados, por exemplo, em textos dos trovadores portugueses: l'amico mio della ventura (Inferno: II, 61). Sobre tal premissa, Alessandro Marchi (2009, p. 25) afirma que ao longo do tempo várias interpretações foram dadas ao verso, todavia as marcas da poesia trovadoresca provençal fazem-se evidentes.

Os tópicos presentes na poesia provençal, assim como na poesia sículotoscana, sempre acompanharam Dante ao longo da sua trajetória poética. É dentro

100 Eu sou Beatriz, ora a fazer-te andar/ do lugar venho a que voltar pretendo/ e amor me move, que faz falar (Tradução de Vasco Graça Moura). 
do quadro poético cortês, ou submerso na atmosfera desse amor que ele constrói o episódio de Francesca (dita da Rimini) e Paolo Malatesta.

Apesar das escassas comprovações, o adultério envolvendo Francesca, filha de Guido da Polenta, aristocrata de Ravena, e Paolo Malatesta ocorrera entre os anos de 1283 a 1286. O acontecimento teve início com um arranjo matrimonial entre as famílias Polenta e Malatesta, até então rivais, que selaria a paz entre as duas casas nobres de Rimini e Ravena. No entanto essa "manobra" não obtém sucesso, pois ao enviar Paolo como porta voz da família Malatesta, como era comum no período, a jovem Francesca entende que Paolo seria o noivo, eis o cerne da história.

Na lendária história de amor entre Tristão e Isolda, profundas semelhanças com o episódio dantesco se entrecruzam, pois a busca de Tristão pela jovem Isolda, a pedido do rei Marcos da Cornualha, assemelha-se a ida de Paolo a procura de Francesca para seu irmão Gianciotto, conforme destaca Figueiredo:

"Tomei o caminho do mar unicamente para buscar a bela dos cabelos de ouro e jurei, se a encontrasse, levá-la ao rei Marcos, que não quer outra mulher. Tenho, pois, que cumprir meu juramento, senhores irlandeses, e não faltarei de modo algum". (FIGUEREDO, 1996, p. 42)

O mito de Tristão e Isolda tem provável origem na lendária história celta, ocorrida na Idade Média e incorporada às histórias do ciclo arturiano. Essa passagem do mito para literatura amorosa medieval alimenta e corporifica a história de Francesca e Paolo, que aparecem no mesmo círculo do inferno que Tristão e Isolda. Isso permite-nos afirmar que a lenda desses amantes era conhecida por Dante.

Ao perceber no ato do matrimônio que o seu pretendente não era Paolo, e sim o seu irmão Gianciotto, um velho deformado, Francesca sofre profundamente, no entanto sem saída casa-se e, logo depois, trai o marido com Paolo, até que Gianciotto os flagra e os mata. O crime é contemporâneo a Dante, que se hospedou na casa do pai de Francesca, Guido da Polenta, e certamente soubera por ele o destino triste da sua filha. 
As informações acerca dessa tragédia familiar, contada ao longo do tempo, encontram no canto V, da Divina Comédia, o único suporte documental; fora isso, não há nenhuma menção oficial. A Enciclopédia Dantesca informa que talvez Alighieri tenha conhecido Paolo Malatesta, entre fevereiro de 1282 a fevereiro de 1283, período em que Paolo exerceu, em Florença, a função de capitão do povo. No mais, as informações históricas apresentam-se em forma de anedotas e deduções fantásticas dos exegetas, que procuram explicar o episódio dantesco à luz de informações historiográficas.

Boccaccio, em Tratatello in laude di Dante, envolve o episódio com ingredientes da literatura Bretã, buscando aproximar o acontecimento ao ciclo arturiano de romances. Em uníssono, aos comentadores contemporâneos a Dante, no século XIX, o crítico italiano De Sanctis elabora um ensaio acerca do episódio, autenticando ainda mais a escolha dos críticos e leitores no que diz respeito ao tal canto.

A crítica em torno do episódio tem momentos diferentes e particulares ao longo do tempo, sendo que seus primeiros comentadores, contemporâneos a Dante, a exemplo de Pietro Alighieri, lacopo Alighieri, L'Ottimo Commento, entre outros, veem na decisão de Francesca marcas de uma mulher adúltera e culpada; por sua vez, a modernidade, de Foscolo a De Sanctis, veem na figura de Francesca a representação da heroína moderna.

Os românticos, em particular, exageraram na interpretação do acontecimento, resultado da atmosfera da corrente literária romântica do século XIX, valorizadora desse sentimento passional e de intrigas familiares. Para esses escritores, esse episódio é visto como a caixa de Pandora.

A intensa fortuna crítica, voltada ao episódio, faz surgir uma série de releituras acerca do universo amoroso de Francesca e Paolo, responsáveis por dar um caráter quase exclusivo ao Canto. A crítica, neste sentido, favorece a busca pela leitura do poeta e, quem hoje se aproxima da Comédia sempre a justifica por ter sabido da história amorosa, envolvendo os dois amantes ou ainda do episódio do Conde Ugolino. Paulo Valesio (apud RENZI, 2007, p. 7) afirma que o episódio é uma metonímia de toda a Comédia. 
A história envolvendo Francesca e Paolo é transformada em poesia universal, e aquele que entra em contato com a versão dantesca não percebe apenas um fato, mas sente a fruição do eu lírico, lapidador do verso, que nos remete às seguintes palavras de Aristóteles na Poética: la poesia è materia più filosofica ed elevata della storia: la poesia, infatti, tratta specialmente l'universale ${ }^{101}$. Para o filosofo a história concentra a sua explicação no particular, enquanto que a poesia universaliza o fato, o que fez Dante ao narrar a história dos amantes.

A entrada de Francesca, no cenário da Comédia, deve ser compreendida a partir do gênio poético do autor, assim como da construção espacial da obra. A geografia infernal pensada pelo florentino determina a cada personagem o lugar a ser ocupado; Minòs, demônio mitológico, tem a função de guardião, alocando as almas nos círculos que lhes cabem juiz infernal, ele observa e com sua cauda longa direciona o pecador ao espaço onde se cumprirá a pena.

O episódio é de fato, o momento em que Dante faz emergir a sua mudança de concepção amorosa, apresentando ao leitor o comportamento moral, espécie de guia ideológico das relações amorosas do homem da sua época. Para o poeta florentino era preciso abandonar as experiências anteriores e assumir os riscos de uma nova poesia que estivesse relacionada ao divino, e abandonasse a relação amorosa trovadoresca.

A aprendizagem poética recebida, ao longo dos anos, por figuras como Brunetto Latini, Arnald Daniel, assim como pelos trovadores da Provença e poetas da fase sículo-toscana fizera florescer uma concepção amorosa particular e cheia de novidade.

O relacionamento de Dante com a tradição provençal não perdura por muito tempo, pois o modelo de poesia que chegou a Florença em sua época era aquele produzido pelos poetas sículo-toscanos, logo mais substituído pelo estilnovo, concepção talvez responsável pelo deslocamento de Eros, que ganha nova definição, bem expresso por Renzi:

II pellegrinaggio di Dante attraverso i tre regni dell'Aldilà è il segno della sua "conversione" dalla vita mondana a quella spirituale, e

101 A poesia é a matéria mais elevada e filosófica da história: a poesia, de fato, trata especialmente do universal ( tradução nossa) 
anche da una letteratura incentrata sulla lirica d'amore della gioventù alla poesia Cristiana della Commedia, allora l'episodio di Francesca ha il senso di una tappa fondamentale. ${ }^{102}$ (RENZI, 2007, p.7)

A metamorfose de Eros, na passagem da fase lírica (a das Rimas) até a DC, justifica-se a partir do forte embate e inserção da filosofia cristã na Florença do século XIV. A influência do cristianismo é decisiva para Dante pensar não mais no amor como salvação dos amantes e sim, como um sentimento com regras bem estabelecidas que pode levar a danação eterna, se não cumpridas.

A ortodoxia cristã acerca da contenção dos instintos carnais é assunto máximo para a Igreja medieval; é já sabido que a visão do homem da época está substancialmente centrada de forma integral no Cristianismo.

A junção de elementos laicos e ortodoxos cristãos, no universo lírico, é responsável por fazer surgir um novo olhar sobre o amor, dando a Eros características hibridas, o que se traduz em uma transformação nefasta para o casal de amantes. O sentimento codificado por Andrea Capelano na lírica estilnovista pretendeu desvincular-se da ideia de contato e representação real, o que elevou o sentimento à condição divina.

Essa modificação aturde o poeta que, ao dar contornos a Francesca, apavora-se ao perceber o resultado a que Eros submete o casal. $O$ poeta não compreende porque o amor pode ter sido tão cruel. De fato, o ponto central da danação encontra-se na não contenção do instinto carnal, sendo o amor na sua acepção humana, a raiz de todo o mal, como pode ser exemplificado pela seguinte fala de Francesca: Amor condusse noi ad una morte (Inferno: V, 106).

As marcas deixadas por um Eros profano, na tradição amorosa italiana, custam a abandonar a poesia dantesca da fase adulta, pois os fantasmas da poesia juvenil ainda rondam a poesia da Comédia. A poesia acolhida no seio da crescente e temida cristandade busca redefinir o conceito de Eros, todavia para tanto era preciso

\footnotetext{
102 A peregrinação de Dante através dos três reinos do além-túmulo é o sinal da sua "conversão" da vida mundana àquela espiritual, e também de uma literatura centrada na lírica amorosa da sua juventude à poesia Cristã da Comédia, então o episodio de Francesca tem um sentido de uma etapa fundamental . (Tradução nossa).
} 
proibir obras da literatura clássica, capazes de contribuir para a continuidade de Eros profano, ou seja, aquele trovadoresco.

A Igreja sempre proibiu a leitura de textos da literatura clássica que fizessem alusão ao amor terreno. Contudo, é intrigante o fato de Francesca responsabilizar a leitura como primeira raiz motivadora da traição, conforme fica nítido no verso: Noi leggiavamo un giorno per diletto di Lanciotto come amor lo strinse; soli eravamo e sanza alcun sospetto ${ }^{103}$ (Inferno, V, 127-129).

Os grandes teólogos da Igreja Medieval, por exemplo, preocupados com informações contidas em alguns textos da literatura clássica vetavam sua leitura e difusão, com o intuito de controlar os seus fiéis. Santo Agostinho condenava, por exemplo, as fábulas pagãs; São Jerônimo, por sua vez, a apresentação às jovens de leituras relativas ao casamento, sexo e matrimônio.

Diante disso a leitura permitida era proposta a partir do olhar cristão. Muitas obras, a exemplo da Eneida, foram bastante aceitas por conterem em seu cerne uma relação direta com os valores cristãos. Tradicionalmente, a figura de Virgílio está relacionada, ao inferir nas entrelinhas da Eneida, a uma ideia messiânica, ou seja, a obra já anunciava, de certo modo, a vinda do Messias. Auerbach analisa a figura de Virgílio como a de um lendário poeta que aos poucos vai ser transformando em um profeta pagão (AUERBACH, 2009, p.43).

Essa moderação efetuada pela Igreja constrói uma camuflagem em obras capazes de despertar o desejo, ou mesmo naquelas explicitamente eróticas. Como era impossível substituir completamente tais obras literárias clássicas, do período pagão, por textos cristãos, os opositores cristãos ${ }^{104}$ buscavam revestir os clássicos de um caráter cristão. Santo Agostinho, por exemplo, era opositor das fábulas pagãs, mas seu pensamento se modifica em virtude do valor alegórico dessas fábulas, que ajudariam na interpretação da Bíblia, em sua acepção moral.

A Bíblia foi livro base para Dante pensar na disposição da sua Comédia. Os dois mundos, que correspondem à ordem Divina, presentes no Livro Sagrado, a

\footnotetext{
${ }^{103}$ Um dia a ler com ele me deleito/ de Lançarote, amor como o prendeu/ Éramos sós e nada a nós suspeito (Tradução de Vasco Graça Moura).

${ }_{104}$ Os opositores eram pensadores clérigos que combatiam o pensamento dominante da Igreja e mantinham-se no interior desta, tais como Santo Agostinho e Tomás de Aquino.
} 
saber: Inferno e Paraíso, marcam o direcionamento do homem virtuoso, cujo olhar volta-se para o céu, e também homem estulto que segue sua própria voluntas, visando à escolha livremente do caminho da danação. A liberdade para Dante ocupa lugar preponderante, ele deseja através da poesia poder apontar, ao homem, a sua capacidade universalista, que Ihe diferencia dos animais.

Diferente dos animais, o homem é dotado de liberdade de escolha, fator importante para compreender a intenção dantesca com a Comédia, uma vez que a livre escolha para nosso autor encontra no intelecto o caminho, sendo o homem responsável por decidir de modo reflexivo o seu destino na terra.

Nesse contexto a razão apresenta-se ligada, fundamentalmente, a uma disposição individual de poder escolher o amor de Deus, ao passo que as benesses terrenas podem trazem resultados nefastos. $O$ amor de Francesca tem uma propensão ao deleite, pouco racional e bastante ingênuo, conforme notamos no verso: noi leggiavamo um giorno per dileto. Assim, pode-se dizer que a leitura proibida foi feita sem aporte na razão, por meio do amor excessivo e pouco racional. Auerbach (2009, p. 97) afirma que o amor natural pode ser corrompido pelo excesso ou pela escolha equivocada do seu objeto, sendo que essa corrupção geraria o pecado.

Frequentemente utilizado neste Canto, o vocábulo amor se repete três vezes a cada três versos, entre os versos 100 e 106, vejamos:

Amor, em paga exige igual ternura,

Tomou por ele tal prazer meu peito,

Que, bem o vês, eterno me perdura.

"Amor nos igualou da morte o efeito:

A quem no-lo causou, Caína, esperas". (Inferno, V, 100-105) 
Essa recorrência anafórica cria um direcionamento profundamente lírico, sobrepondo-se ao conteúdo narrativo. Todavia, o aspecto narrativo não se ausenta em nenhum momento do texto, sendo que os fatos são, por sua vez, mencionados de forma alusiva a fim de caracterizar o lírico.

É verdade que a definição do lírico é delicada e complexa para os estudos de teoria literária. Tal conceito se dá a partir da ideia do discurso que se caracteriza em primeiro lugar, de modo evidente, por sua natureza versificada. A criação poética da Idade Média, no momento em que o lírico era produto da união, voz com os acordes da lira, seria responsável, mais tarde, por definir a poesia amorosa. Essa definição também busca aporte na concepção aristotélica de poesia que apresenta a noção de palavras agradáveis, possuidoras de uma semelhança rítmica e musical, vejamos:

Poichè l'imitare, la musica e il ritmo sono connaturati in noi ( $\mathrm{i}$ versi, è chiaro, sono parti dei ritmi), da principio chi aveva specialmente un'inclinazione naturale verso di essi a poco a poco genero la poesia spontaneamente $^{105}$ (ARISTOTELE, 2009, p. 34)

As palavras pertencentes ao universo lírico no Canto $V$ fazem referência ao grande hino da poesia estilnovista, presente no célebre terceto: Amor, ch'al cor gentil ratto s'apprende (Inferno, V, 100), que, por sua vez, alude ao início da poesia di Guido Guinizelli, já estilnovista, em que se lê: Al cor gentil rempaira sempre amore, manifesto responsável por sugerir a mudança poética italiana no século XIII.

Essa canção-manifesto dos poetas estilnovistas, parafraseada por Francesca no inferno, alude ao forte apego de Dante à sua fase juvenil. As semelhanças lexicais e rítmicas do estilo novo, presentes no canto $V$, são importantes para compreender a concepção amorosa dantesca, ainda seguindo os passos de Guinizelli.

Vale ressaltar que o amor pensado por Guinizelli, na canção fundadora do novo, não incita o contato carnal e físico, pois é um sentimento virtuoso, ansioso por corações puros e gentis capazes de acolhê-lo. Esse conceito amoroso guinizelliano

\footnotetext{
${ }^{105}$ Dado que o imitar, a música e o ritmo são conaturais em nós (os versos, é claro fazem parte do ritmo) desde o princípio quem tivera especialmente inclinação natural a esses elementos que pouco a pouco gerou a poesia.
} 
funde amor com o coração gentil, ou seja, somente almas preparadas e que tenham amor e gentileza podem vivenciar tal experiência.

A modificação da concepção amorosa na poesia italiana tem na canção guinizelliana o seu germe, conforme explicado. Quando a canção ganha notoriedade e difusão, Dante e Guido Cavalcante ainda eram adolescentes, portanto, cresceram já sobrepostos a uma poesia separada daquela anterior, isto é, a poesia de Guittone, lacopo da Lentini e todos os outros pertencentes à escola sículo-toscana.

O amor suscitado por Francesca tem suas raízes na visão estilnovista; é um amor que se aporta em corações preparados para recebê-lo, entretanto, Francesca não soube viver esse amor, pois, estava prometida a outro homem e, também, para a moral cristã. Assim como para a poesia dantesca, que passou por esse filtro, o adultério anula nos corações a presença do amor.

O amor não perdoa os corações incapazes de racionalizar os seus efeitos. Guinizelli pensa em uma teoria amorosa que pudesse talvez aliar-se à concepção cristã, que será confirmada, por Dante, com o episódio de Francesca e Paolo. Os amantes imaginam estarem preparados, mas não estão, pois o amor não permite a desobediência de uma ordem divina.

A incompreensão dantesca está centrada na impossibilidade de compreender a danação do casal, pois a história apresentada por Francesca é comovente, visto que o amor sempre trouxera ao poeta boas recordações. Unido à condição divina, o amor já não poderia mais aceitar o amor-adúltero, mesmo que o casal ainda permaneça eternamente ligado. No Inferno eles continuam juntos. O vínculo estilnovista, entretanto, os condena por infringirem a uma ordem divina, o amor sublime. 


\subsection{MATELDA}

A aparição de Matelda nos últimos momentos da ascese dantesca, na montanha do purgatório, coloca em debate, a princípio, o significado dessa aparição feminina, bem como sua relação com as figuras históricas.

As possíveis proximidades entre a Matilde de Dante e mulheres como a Condessa Matilde de Canossa ou ainda as místicas alemãs, Matilde de Magdeburgo e de Hackeborn, relacionam-se à escolha da vida contemplativa, sendo que essas outras mulheres foram analisadas, ao longo do tempo, por uma crítica desejosa de elucidar as intenções de Dante ao apresentar esta figura complexa.

As interpretações em torno da Matelda dantesca caminham no sentido de compreendê-la como uma mulher viva, já que a grande maioria dos personagens dantescos tem o seu correlato histórico, desse modo, é necessário pensar um corresponde próximo a ela para assim explicar a sua aparição.

Entretanto, é importante sondar os passos do poeta quando explica a sua obra como um fato alegórico cheio de imagens simbólicas, elementos que, segundo ele, traçam a geografia do segundo reino, onde o espírito humano busca a purificação. Dentro desse quadro, Matelda figura como uma das maiores e mais complexas invenções do poeta florentino. Ao longo dos anos, os intérpretes da Comédia fazem uma leitura da aparição de Matelda, centrada na relação entre figura real - pessoa viva e histórica - e poética, buscando semelhanças entre essas duas relações, na tentativa de entender o texto do poeta florentino.

$\mathrm{Na}$ sua carta a Cangrande Della Scala, o poeta endereça o Paraíso, oferecendo e explicando ao vicário de Verona o acesso à obra, assim como, suas intenções. O poema constrói-se, a partir de uma complexa estrutura espacial, sendo que Dante dá ao Purgatório o caráter máximo da alegoria, concretizando uma realidade geográfica inédita. O poeta, na verdade, pintou e deu vida, grosso modo, ao universo "purgatorial".

Sabidamente o poeta não cria o Purgatório; esse lugar "intermediário" já estava presente nos discursos dos padres da Igreja Medieval, responsáveis por 
apresentá-lo de forma doutrinária. O concílio de Lion, em 1274, oficializa sua existência e caráter. A criação do purgatório, palavra oriunda do latim purgare, vem responder aos anseios de almas que morrem no estado de graça porém, ainda imperfeitas para alcançar o paraíso e assim a redenção. Coube, portanto, à Igreja explicar essas inquietações provenientes dos seus fiéis, certos da impossibilidade de pureza total.

A localização do Purgatório é antitética em relação ao Inferno; A este propósito, Petrocchi assinala as diferenças pontuando que enquanto o purgatório é uma montanha, o inferno é uma cavidade subterrânea situada no hemisfério oposto àquele de Jerusalém, em uma grande ilha em forma de cone (PETROCCHI, 2009, p.87). Essas características compositivas e diferenciadoras do mundo além-túmulo são importantes por marcar a Divina Comédia como uma obra que apresenta o Purgatório imerso em uma atmosfera branda, repleta de nuances, que singularizam Dante como o poeta construtor do mundo da purgação, instituído pela Igreja.

Além dos elementos espaciais, a mudança de linguagem e tom são novidades absolutas nessa obra-prima. Se de um lado os diálogos no Inferno são escuros e dotados de grande força expressiva; no Purgatório a mudança segue justamente as intenções compositivas do espaço, constituindo-se em uma poesia mais serena em seus argumentos. A lógica poética na construção dos reinos pós-morte, em particular o inferno e o purgatório, pode ser entendida na estruturação das penalidades em ambos os reinos.

A diferença das penas, nos dois primeiros reinos da Comédia é dúplice. No Purgatório, as almas devem, além de subir em direção ao Paraíso, buscar meios para superar a fase de sofrimento, preparando-se para o gáudio eterno; já no Inferno os danados são eternizados na sua respectiva pena. Petrocchi esclarece de maneira clara essa diferença, vejamos:

Al patimento è unito un esempio morale, di segno opposto a quello del peccato che le anime scontano nel secondo regno, e che è indispensabile affinchè esse siano in grado di esercitare, o, meglio, di prepararsi ad esercitare la virtù di cui difettarono in vita, meditando 
sulla virtù e aspirando fortemente ad essa ${ }^{106}$.(PETROCCHI, 2009, p.67)

Para uma melhor compreensão da poesia da Comédia, a figura do leitor é fazse necessária. Não se pode esquecer que a obra escrita foi escrita em uma língua vulgar, ou seja, diferente do latim áulico, e que reúne conhecimentos enciclopédicos voltados àqueles que não sabiam ler no latim medieval, língua em frequente embate com os falares locais. Assim, o poeta desejava aproximar uma gama maior de pessoas ao conhecimento. A respeito desse leitor dantesco, Spera diz:

Ho volutamente ripreso alcuni aggettivi utilizzati dallo stesso Dante nell' Epistola a Cangrande per delineare il suo modello di lettore: " benevolum, attentum et docilem. II lettore sara attento perchè colpito dal carattere straordinario dei fatti narrati, ma dovrà essere anche benévolo e docile di fronte a uma matéria diversa, a discorsi esplicativi, propri di uma poesia della conoscenza. ${ }^{107}$ (SPERA, 2010, p.17)

A entrada de Matelda no cenário do Purgatório é essencial para direcionar o leitor à compreensão de sua chegada, bem como apresentação como uma sacerdotisa dantesca. Na divina floresta, oposta àquela do Inferno, Dante é envolvido por um desejo imenso de conhecê-la. Se antes, na selva infernal, Dante pensa em desistir, na floresta do Éden o sentimento é outro, ele quer explorá-la, conhecê-la, sentir bem devagar o doce encanto do fim do trajeto, conforme registrado pelos seguintes versos do Purgatório:

Vago già di cercar dentro e ditorno

La divina foresta spessa e viva,

\footnotetext{
${ }^{106}$ Ao sofrimento é unido um exemplo moral, oposto àquele do pecado que as almas descontam no segundo reino, e que é indispensável afim que elas estejam preparadas para exercitar, ou melhor, se preparar a exercitar a virtude cuja não cumpriram na vida, meditando sobre a virtude e aspirando a ela (Tradução nossa).

${ }^{107}$ Seguidamente retomo alguns adjetivos utilizados por Dante na Carta a Cangrande para delinear o seu modelo de leitor: "benevolente, atento e dócil". O leitor será atento porque tocado pelo caráter extraordinário dos fatos narrados, devendo ser também benevolente e dócil diante de um assunto diferente a discursos explicativos característicos de uma poesia do conhecimento (Tradução nossa).
} 
Ch'a li occhi temperava il novo giorno,

Sanza più aspettar lasciai la riva

Prendendo la campagna lento lento

Su per lo suol che d'ogne parte auliva ${ }^{108}$ ( Purgatorio, V, 1-6)

Como podemos perceber as impressões suscitadas por Dante ao adentrar a floresta do Éden já antecipam a chegada da figura de Matelda, personagem enigmática e cheia de poesia. A descrição física do Éden encontra na linguagem o suporte capaz de projetar o universo particular do purgatório, sendo nos limites do paraíso que o poeta descreve o encontro mais sublime de toda a Comédia.

Nos tercetos acima, a atmosfera da divina floresta é apresentada com detalhes impressionantes, a começar pela sensação visual da chegada, marcada pela claridade do ambiente, ch' a li occhi temperava il novo giorno, a áurea doce e sem mudança provoca outra sensação, a do vento que toca o rosto do poeta trazendo as imagens alusivas ao novo espaço ao seu redor. Assim, o sentir torna-se uma experiência para o poeta.

Ainda sobre os sentidos, Dante serve-se da visão para fazer com que o leitor construa a paisagem tal qual ele deseja; os ramos que balançam, os pássaros que festejam, a água límpida do rio, por exemplo, são descritos pelo olhar atento do viajante. Essa frequência no uso dos sentidos tem justificativa na forte relação entre o Éden dantesco e as paisagens terrenas. Chiavacci (2009, p. 820) argumenta que o Éden dantesco busca imitar a paisagem terrena, a crítica fala da dupla relação: a de continuidade e diferença, que caracterizam as intenções do poema sacro.

A aparição de Matelda se dá nesse cenário realista, sendo que as imagens trazidas por Dante induzem o leitor a pensar esse realismo presente na figura de Matelda como a representação de uma mulher real, histórica. As características apresentadas por essa mulher marcam a presença do seu correspondente histórico,

\footnotetext{
108 Já buscar dentro e em volta desejava/ a divina floresta espessa e viva/ que aos olhos novo dia temperava/ e sem tardar, da margem em deriva/atalhei pelo campo, muito lento/na terra a rescender toda efusiva. (Tradução Vasco Graça Moura).
} 
o sorriso, no qual o cantar em meio ao jardim, para Chiavacci, é o cenário feito para ser habitado por um ser humano.

A amenidade do jardim, pintado por Dante, provoca uma recordação da sua poesia melódica, fortemente influenciada por Guido Guinizelli e Guido Cavalcanti, ambos, por sua vez, influenciados pela poesia laudatória de São Francisco de Assis, cujo texto, $O$ cântico às criaturas, funda a tradição literária italiana na vertente religiosa, representando o primeiro poema em língua vulgar. Para Malato, São Francisco desenha com este poema um quadro de grande novidade (MALATO, 1995, 356).

A presença de uma paisagem com características terrenas faz do Éden dantesco um hino de louvor semelhante ao Cântico das Criaturas. O espaço do jardim percorrido por Dante é a todo o momento envolvido nessa atmosfera de louvor, conforme a descrição feita nos seguintes versos do Purgatório:

\author{
Per ciu le fronde, tremolando,pronte \\ Tutte quante piangevano a la parte \\ u' la prim' ombra gitta il santo monte \\ non però dal loro esser dritto sparte \\ tanto, che augelletti per cime \\ lasciasser d'operare ogne lor arte (Purgatorio, XXVII, v 10-15)
}

Com o "Cântico das Criaturas", São Francisco estabelece um elo entre o criador e a criatura, ou seja, a criação reflete a face de Deus, assim como todos os elementos que integram o universo, envolvendo o homem no mistério divino. Vejamos:

Laudato sie, mi'senhore cum tucte le tue creature, 
Spetialmente messor lo frate sole,

Lo qual è iorno, et allumini noi per lui ${ }^{109}$

Após a descrição espacial, entra em cena a figura de Matelda, elemento central dessa paisagem; A partir da visão desse novo elemento, próximo ao rio do Éden, Dante inicia mais uma etapa, na qual Matelda atuará como elo entre Alighieri e Beatriz. Essa aparição deixa o poeta maravilhado, trata-se de uma visão súbita e responsável pela mudança de linguagem, que faz com que traços lexicais estilnovistas surjam e pintem a cena, conforme os seguintes versos:

... e la m'apparve, si com'elli appare

Subitamente cosa che divisa

per maraviglia tutto altro pensare

una donna soletta che si gia

e cantando e scegliendo fior da fiore

ond'era pinta tutta la sua via ${ }^{110}$ ( Purgatorio, XXVIII. V 37- 42)

As recordações da sua fase juvenil evidenciam-se no surgimento de Matelda, já nomeada como "donna", substantivo bastante utilizado pelos poetas italianos, em particular pelos estilnovistas. O poeta usa um especificador ligado ao substantivo donna, ou seja, soletta, cuja função é indicar uma mulher que turba qualquer pensamento.

O olhar de Dante volta-se à figura feminina mais significativa depois de Beatriz. O canto introduzido por Matelda, assim como sua atitude de colher flores,

${ }^{109}$ Louvado seja o Senhor em todas as criaturas/ Especialmente o irmão Sol/ o qual é dia e nos ilumina. (Tradução nossa).

110 (...) e me surgiu, tal como se depare /subitamente cousa que desvia/ por maravilha a todo o outro pensar/ uma velida só que por lá sei ia/ a cantar e a escolher flor e mais flor/das que esmaltavam toda aquela via. (Tradução Vasco Graça Moura). 
outra alusão bastante estilnovista, faz o poeta reviver o momento mais próximo de Beatriz, aquele da criação mais sublime, o do livro da sua memória: a Vida Nova.

Os traços responsáveis por compor a figura de Matelda são apresentados pelo poeta, com um tom absolutamente similar ao da sua fase juvenil, como a experiência do ragionar d'amore, muito cara ao poeta. Elementos oriundos da natureza atuam como uma âncora para o poeta recordar suas rimas doces e amorosas, e podem ser exemplificados pelo gesto de Matelda colher flores vermelhas e amarelas ("volsesi in su i virmigli e in su i gialli"). Aqui a sua feição é comparada a de uma jovem intimidada ao avistar o cavaleiro conforme o verso, "che vergine che li occhi onesti avvall’, que possui características da poesia amorosa italiana.

Matelda tem sua caracterização construída aos poucos, sendo que ela aparece de forma silenciosa, entoando um canto e colhendo flores, imagens de um Dante estilnovista e saudosista em retomar a poesia dos fiéis ao amor. A dança iniciada por Matelda, por exemplo, segundo Barbara Reynolds (2006, p. 339) é uma referência à ideia que o poeta tinha em coreografar as suas baladas, destinadas ao canto e à dança, semelhantes àquelas enviadas a Beatriz.

As recordações enriquecem profundamente a narrativa que apresenta elementos do folclore Florentino. No verso la gran variazioni d'freschi mai, os ramos verdes ou floridos, aludem, em especial, às festas de calendimaggio ${ }^{111}$,onde esses ramos eram utilizados para adornar as portas ou as janelas das jovens como sinal de homenagem. Eles também eram colocados pelas estradas para festejar a chegada da primavera (MARCHI, 2009, p. 553).

A primavera, como estação do florescer da natureza, encontra na poesia estilnovista espaço adequado. As recorrências a que o poeta faz ao léxico, próprio dessa estação do ano, direcionam a poesia amorosa a um lugar onde a beleza da mulher é sempre comparada aos elementos próprios da natureza, sendo que a primavera é a que melhor revela tal relação.

\footnotetext{
111 Festa da cultura italiana que acontece no mês de maio, festa ligada a primavera, flores são jogadas pelas ruas e nas portas da donzelas em sinal de cortesia.
} 
As flores colhidas por Matelda remetem à poesia juvenil da escola estilnovista, cuja ideologia contribui na formação da imagem da personagem presente no jardim do Éden, espécie de fronteira entre o Purgatório e o Paraíso. A floresta da qual Matelda é a guardiã, além de apresentar uma atmosfera tranquila, será o lugar de purgação de Dante, para que ele ascenda ao Paraíso, livre de qualquer mácula. $O$ diálogo entre o poeta e Matelda esclarece de maneira precisa a função dessa figura feminina, vejamos:

\section{“L'aqua diss'io e l'suon de la foresta Impugnan dentro me novella fede di cosa ch'io udi' contraria a questa. Ond'ella: lo dicerò come procede} per sua cagion cio ch'ammirai ti face, e purgherò le nebbia che ti fiede ${ }^{112 " . ~(P u r g a t o r i o, ~ X X V I I I: ~ 85-90) ~}$

As impressões causadas pela floresta do Éden transmitem a Dante contrário àquelas infernais que deixaram lembranças nefastas ao poeta - valores como confiança e esperança, renovando as forças de um viajante cansado e desejoso pela chegada ao ponto final da sua trajetória.

A intervenção de Matelda nos tercetos acima confirma a sua função no Purgatório, isto é, a de purificadora. É a figura feminina exercendo a função de sacerdotisa, ou seja, a imersão de Dante nos rios Leté e Eunoé, ambos purificadores, fazem com que a presença de Matelda aluda à figura de um sacerdote que pelo ministério concede ao fiel, o batismo.

O batismo, na tradição cristã, tem exatamente as características daquele efetuado por Matelda, isto é, a de conceder vida nova, selando o ingresso do fiel à

\footnotetext{
112 "A água, disse eu, "e o som cá da floresta/ que impugne nova fé em mim já pede/ de cousa que eu ouvi contrária a esta. Onde ela: Eu te direi como procede/ por sua causa que eu admirar te faz/ e purgarei a névoa que te impede. (Tradução de Vasco Graça Moura).
} 
comunidade de crentes, e propiciando o nascimento de uma nova pessoa. A imersão de Jesus Cristo nas águas do rio Jordão cumpre a função de ligar o filho ao pai, e à entrada no reino do pai; semelhanças profundas que entrecruzam o evangelho de Mateus e o canto XXVIII, indica momentos cruciais para a entrada de Dante no Paraíso.

Os momentos antecedentes à ascensão de Dante ao Paraíso são de uma perfeita descrição espacial em que Matelda continua figurando como personagem central. No início do Canto XXIX, a personagem entoa o salmo XXXI responsável por modificar o ambiente sentido pelo poeta, vejamos:

\author{
E una melodia dolce correva \\ per l'aere luminosa; onde buon zelo \\ mi fé riprender l'ardimento d'Eva ${ }^{113}$ (Purgatorio, XXIX, 22-24)
}

O canto é descritivamente voltado à figura feminina, capaz de intermediar a entrada do poeta no Paraíso. A descrição espacial em tal canto antecipa as sensações que o poeta encontrará no Paraíso. Na verdade, a floresta do Éden já faz parte da composição paradisíaca, que logo será morada do viajante.

O verso, mi fé riprender l'ardimento d'Eva, trata-se de uma comparação que o poeta efetua com o objetivo talvez de aproximar as sensações provocadas pela aparição de desejos por experimentar, de imediato, as benesses do espaço. Essa ardilosa vontade que agora pode ser, de fato, experimentada, causa a lembrança da vontade de Eva em experimentar do fruto proibido.

Essas sensações fazem Dante sentir as primícias, próprias da visão de Deus, sendo que sua capacidade de poeta não lhe permite exprimir em versos tal visão, assim como as sensações espaciais surgidas após a sua purificação, conforme se evidencia nos seguintes versos:

\footnotetext{
${ }^{113}$ E perpassava doce melodia/ pelo ar luminoso; e o zelo meu/ a Eva me fez repreender a ousadia. (Tradução de Vasco Graça Moura).
} 
O sacrosante Vergini, se fami,

freddi o viglie mai per voi soffersi,

cagion mi sprona ch'io merce vi chiami ${ }^{114}$.

Desse modo, outras figuras femininas são evocadas como protetoras do poeta, certo de que o seu engenho e sua dedicação à entidade pagã das musas, seres da mitologia greco-romana, responsáveis por fazer eivar no poeta a capacidade inspiradora, possam ajudá-lo na construção de versos possíveis para descrever o ambiente. É o momento central para que Dante sinta que seu talento poético é incapaz de reproduzir as imagens tão próximas de Deus. A recorrência às musas, assim como a presença de Matelda, são importantes para a compreensão da sua forte relação com o universo feminino, que perdura por toda a Divina Comédia.

${ }^{114}$ Santas Virgens, por vós, se alguma vez/ fome, frio ou vigílias já sofri/ tempo me aperta a vós pedir mercê. (Tradução de Vasco Graça Moura). 


\section{CONCLUSÃO}

A poesia medieval italiana ganhou, a partir de Dante Alighieri e da criação do doce estilo novo, uma fisionomia particular. O objetivo do poeta, assim como da escola que fundou esse estilo, foi elaborar uma nova pátria para a poesia, na qual a mulher tornou-se o centro representativo dessas composições. A poesia amorosa dantesca encontra, historicamente, a figura feminina imersa em dois opostos representativos: de um lado Eva como pecadora, e do outro, Maria, mãe de Jesus. Vale ressaltar que, no século da produção lírica de Dante, a imagem feminina já estava intimamente ligada a Virgem Maria, tida como centro do universo feminino no século XIV.

Nesse contexto, o perfil mariano com suas características de pureza, amor, suavidade e intimidade com o Divino, será elemento aproveitado pelos poetas estilnovistas na construção da imagem da mulher.

As poesias da fase experimentalista, de escambo, ou seja, troca poética com amigos da envergadura de Guido Cavalcanti, como Dante da Maiano, Monte Andrea e aquelas poesias, que compõem o prosimetro da Vida Nova, apresentam um poeta elaborador de uma imagem feminina muito próxima à figura de Maria. Beatriz sem dúvidas é o modelo feminino maior, sendo que ao longo da construção poética de sua musa, outras mulheres como, Donna gentile, donna schermo, comporão o universo do poeta.

Essa relação profunda e de intensa novidade com o universo feminino, durante a fase lírica amorosa do poeta, escorrerá até a composição da Comédia, obra de sua fase adulta. A linguagem bem como a descrição das características femininas, próprias dessa escola (o estilo novo), far-se-ão presentes na apresentação da história amorosa de Francesca e Paolo, no Canto V do Inferno, assim como na aparição de Matelda nos Cantos finais do Purgatório. Essa recorrência faz com que a mulher, na visão poética de Dante, seja construída a partir das suas experiências, em especial, em sua arte de produzir palavras em rimas, notadamente ligada à escola florentina, pilar na elaboração de um novo conceito poético feminino. 


\section{REFERÊNCIAS BIBLIOGRÁFICAS}

ABELARDO, Pietro. Storie delle mie disgrazie, lettere d'amore di Abelardo e Eloisa. Trad. Federico Roncoroni. 14 Ed. Milano: Garzanti, 2009. Título original: Historia calamitatum.

ALIGHIERI, Dante. A Divina Comédia. Trad. Vasco Graça Moura. São Paulo: Landmark, 2005. Título original: La Divina Commedia.

ALIGHIERI, Dante. Dante Lírica. Trad. Jorge Wanderley. Rio de janeiro: Top Books, 1996. Título original: Rime / Vita Nuova.

ALIGHIERI, Dante. La Divina Commedia. Org. Alessandro Marchi. Varese: Mondadori, 2009.

ALIGHIERI, Dante. Rime. Milano: Bur Rizzoli, 2004.

ALIGHIERI, Dante. Le Rime della Vita Nuova e della giovinezza, a.c di M. Barbi e F. Maggini, Firenze, 1956.

ANGIOLILLO, Giuliana. Un'isola “autobiografica” Viaggio nella medievalità di Dante. Ed. Salermo: Salermo, 1994.

ARISTOTELE. Poetica. A cura de Andrea Barabino. Milano: Mondadori, 2009. 
ARISTOTELE. Poetica. Trad. Andrea Barabino. Ed. Milano: Mondadori, 2009. Título

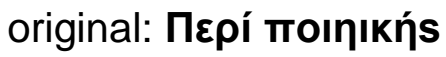

AUERBACH, Erich. Studi su Dante. 5 Ed. Trad. Maria del Pieri Bonino. Milano: Feltrinelli, 2009. Título original: Dante Als Dichter Der Irdischen Welt.

BADINI, Gino. Matilde a Canossa. Ed. Canossa: Museo nazionale, 2009.

BENISCELLI, Alberto; COLETTI, Vittorio. Strumenti Per lo Studio Della Letteratura Italiana. Ed. Firenze: Instituto Geográfico De Agostini Le Monnier, 1992.

BENVENUTI, Anna. II mito di Matilde nella memoria dei cronisti fiorentini. In: GOLINELLI, Paolo. Matilde di Canossa nelle culture europee del secondo millennio: Dalla storia al mito. Prima Edizione. Bologna, 1999, p. 54.

BERTINI, Ferruccio. Medioevo al femminile. Ed. Roma: Laterza, 1996.

BIONDOLILLO, Francesco. Le rime Amorose di Dante. Firenze: Casa G. D' Anna, 1964.

BOLOGNA, Corrado. II ritorno di Beatrice: Simmetrie Dantesche fra Vita Nova, Petrose e Commedia. Roma: Salermo, 1998.

BORSELLINO, Nino. Ritratto di Dante. Roma: Laterza, 2007. 
BOSSIER, P.G. La Maniera Mutata? Un'indagne intorno alla storiografia dei 'plagenti ditti de l'amore' da Bernardo di Chiaravalle sino a Dante Alighieri. Augustus, 2008.

BOYDE, Patrick. Retorica e stile nella lirica di Dante. Trad. Corrado Calenda. Napoli: Liguori, 1979. Título original: Dante's Style in his Lyric Poetry.

BRUN, Garin Lo. L'ensegnamen alla Dama. Trad. Laura Regina Bruno. Ed. Palermo: Archivio Guido Izzi, 2001.

CAMPANINI, Naborre. Canossa: Guida Storica. $4^{\circ}$ Ed. Reggio Emilia: Bizzocchi, 1975.

CAPELÃO, André. Tratado do amor cortês. Trad. Ivone Castilho Benedetti. São Paulo: Martins Fontes, 2000. Título original: Tractatus de Amore.

CARRAI, Stefano. Vita Nova. Ed. Milano: Bur Rizzoli 2009.

CONTINI, Gianfranco. Rime. Ed. Einaudi: Torino, 1995.

CROCE, Benedetto. La poesia di Dante. Bari, Laterza, 1957.

DALARUN, Jacques di. La donna vista dai chierici. In: DUBY, Georges; PERROT, Michelle. Storia delle donne. 8ª Edição. Bari, Italy: Laterza, 2009, p. 24-25. 
DUBY, Georges. Il potere delle donne nel Medioevo. Trad. Giorgia Viano Marogna. Ed. Roma: Laterza, 2008. Título original: Dames Du XII siècle.

. Donne nello specchio del Medioevo. Trad. Giorgia Viano Marogna. Ed. Roma: Laterza, 2008. Título original: Dames Du XII siècle.

. Storie delle donne: il Medioevo. A cura de Christiane Klapisch-Zuber. 8 Ed. Roma: Laterza, 2009.

FERREIRA RIBEIRO, Maria (Org.). 0 que os filósofos pensam sobre as mulheres. Ed. Rio Grande do Sul: Unisinos, 2010.

FERRONI, Giulio. Storia della Letteratura Italiana: Medioevo Latino e Letterature Romanze. Ed. Milano: Mondadori, 2002.

FUMAGALLI, Vito. Matilde di Canossa: Potenza e solitudine di una donna del Medioevo. Ed. Bologna: II Mulino, 2002.

GESSANI, Alberto. Dante, Guido Cavalcanti e I" "amoroso regno". Ed. Roma: Quodlibet, 2004.

GHETTI, Noemi. L'ombra di Cavalcanti e Dante. Ed. Roma: L'Asino d'oro, 2010.

GILSON, Etienne. Dante e la filosofia. Milano, Jaca Book, 1996 
GOLINELLI, Paolo. Matilde di Canossa nelle culture europee del secondo millenio: Dalla storia al mito. Ed. Bologna: Pàtron, 1999.

_. Matilde di Canossa nella letteratura italiana da Dante a Pederiali. Ed. Reggio Emilia: Diabasis, 1997.

GORNI, Guglielmo. Dante: Storia di un visionario. Ed. Roma: Laterza, 2009. inferno 1 Ed. Milano: Mandadori, 2005.

LE GOFF, Jacques. La città Medievale. Ed. Firenze: Giunti, 2010.

LEDDA, Giuseppe. Dante. Ed. Bologna: II Mulino, 2008.

LEONARDI, A.M.C (Org.). In: ALIGHIERI, Dante. La Divina Commedia:

. In: ALIGHIERI, Dante. La Divina Commedia: purgatório. 1 Ed. Milano: Mondadori , 2005.

_. In ALIGHIERI, Dante. La Divina Commedia: paradiso. 1 Ed. Milano: Mondadori, 2005.

LEONARDI, Anna Maria Chiavacci. La Divina Commedia: Lessico Teoloigco Rimario. Ed. Oscar Mondadori: Milano, 2009. 
LUSCOMBRE, David. O Pensamento Medieval. Trad. Lucília Rodrigues. Mem Martins: Europa-América, 2000. Título original: Thought Medieval.

MALATO, Enrico. Dante e Guido Cavalcanti: II dissidio per la Vita Nuova e il Disdegno di Guido. Ed. Roma: Salermo, 1997.

MALATO, Enrico. Dante. Ed. Roma: Salermo, 1999.

MALAVASI, Luca; DORI, Anna; ZANON, Tobi. In: ALIGHIERI, Dante. La Divina Commedia. Ed. Milano: Eli, 2009.

MOLLI, Maria Gian. La Rinascita di Dante. Ed. Roma: Arkeiros, 2010.

ORAZI, Veronica. Sendebar II libro degli inganni delle donne. Ed. Torino: Orso, 2001.

PAZZAGLIA, Mario. II “mito” di Beatrice. Ed. Bologna: Pàtron, 1998.

PETROCCHI, Giorgio. Vita di Dante. Ed. Roma: Laterza, 2008.

REYNOLDS, Barbara. Dante: La vita e l'opera. Ed. Milano: Longanesi, 2006.

ROSA, Asor Roberto. Storia europea della letteratura italiana I: Le origini e il Rinascimento. Ed. Torino: Einaudi, 2009. 
ROUGEMONT, Denis. L'amore e I' occidente: Eros morte abbandono nella letteratura europea. Trad. Luigi Santucci. Ed. Milano: Bur Rizzoli, 2006. Título original: L'Amour et l'Occident.

SANCTIS, Francesco de. Ensaios Críticos. Trad. Antônio Lázaro de Almeida Prado. São Paulo: Nova Alexandria, 1993. Título original: Saggi Critici.

SANGUINETI, Edoardo. Vita Nuova. Ed. Roma: Edizione Garzanti, 2001.

SANTANGELO. Dante e i trovatori provenzali. Ed. Gèneve-Paris: Slatkine, 1982.

SANTUNIONE, Giovanni. Matilde di Canossa: Storie, leggende, scandali, luoghi, itinerari per conoscere la grande contessa. Ed. Modena: II Fiorino, 1996.

SCRIMIERI, Rosário. Lirica, allegoria e storia nella canzone - Tre donne intorno al cor mi son venute. TENZONE. Ver. de la Asoc. Complut. de Dantologia, Madrid, Servicio de Publicaciones de la Universidad Complutense de Madrid, N6, p. 73 89,2005

SPERA, Francesco. La poesia forte del poema dantesco. Ed. Firenze: Franco Cesati, 2010.

SPIKE, Michèle k. Vita di uma donna che trasformò la storia. Ed. Reggio Emilia: Aliberti, 2007. 
SPINA, Segismundo. Introdução à poética clássica. Ed. São Paulo: Martins Fontes, 1995.

THOMASSET, Claude di. La Natura della donna. In: DUBY, Georges; PERROT, Michelle. Storia delle donne. 8ª Edição. Bari, Italy: Laterza, 2009, p. 58.

TRINGALI, Dante. A Arte Poética de Horácio. Ed. São Paulo: Musa Editora, 1993.

Tristão e Isolda. (Trad. Maria do Anjo Braamcamp Figueiredo) Rio de Janeiro, Ed. Francisco Alves, 1996.

VALLI, Luigi. II linguaggio segreto di Dante e dei "fedeli d' Amore". Ed. Milano: Luni, 1994.

VILLANI, Giovanni. Nuova cronica. Trad. Giuseppe Porta. Parma: In Parma, 1991. Título original: Nouva cronica.

ZANCAN, Marina. II doppio intinerario della scrittura: La donna nella tradizione letteraria italiana. Ed. Torino: Einaudi, 1998. 